This repord wat preparod as an accoumt of work tpansored by an agency of the United States

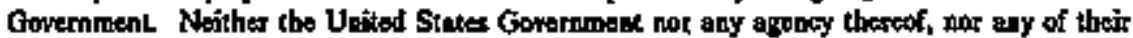
omployeses, makes any warranly, express or imbitiod, of assmmes any legal liability of responsibility for the eccuracy, completeness, of usefulness of any information, apparatur, prodoct, or process diselosed, or reprosents that is use would aot inlinige privatuly owned fights. Roforence hetin to apy specific commercial ptoduct, process, or service by trade name, trademark, manufaturer, or otherwise does not rexessarily constitute or imply its endarsenrent, Jecommendation, or farosing by the United States Government or any agerecy theteof. The ricms

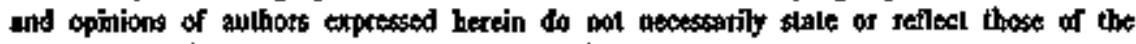
Ualted Stales Goremment of any agency thereof.

\title{
Handbook for Preparation of Individual Procurement Action Report (IPAR)
}

\section{October 1996}

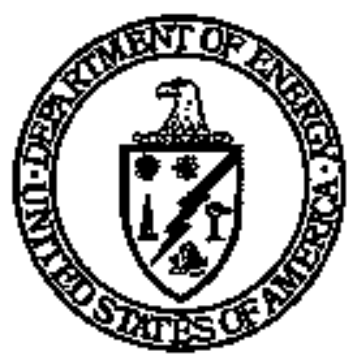

\author{
U.S. Department of Energy \\ Assistant Secretary for Human Resources and Administration \\ Office of the Deputy Assistant Secretary \\ for Procurement and Assistance Management \\ Washington, DC 20585
}




\section{DISCLAIMER}

Portions of this document may be illegible in electronic image products. Images are produced from the best available original document. 


\title{
TABLE OF CONTENTS
}

\author{
HANDBOOK \\ FOR \\ PREPARATION OF \\ INDIVIDUAL PROCUREMENT ACTION REPORT (IPAR)
}

PAGE

$\begin{array}{lr}\text { INTRODUCTION } & 1\end{array}$

IPAR FORM DOE 4200.40 - PROCUREMENT ACTIONS ONLY 2A

IPAR FORM DOE 4200.40A - FINANCIAL ASSISTANCE ONLY 2B

IPAR FORM DOE 4200.41 - IPAR SUPPLEMENT ～2C

PROCUREMENT ACTIONS - BY ELEMENT 3

IPAR SUPPLEMENT INSTRUCTION - BY ELEMENT

FINANCIAL ASSISTANCE ACTIONS - BY ELEMENT

IPAR SUPPLEMENT INSTRUCTION - BY ELEMENT

APPENDIX A - REQUIRED ITEMS - QUICK REFERENCE - PROCUREMENT - $\quad 82$

APPENDIX B - REQUIRED ITEMS - QUICK REFERENCE -

FINANCIAL ASSISTANCE 89

APPENDIX C - STATE ABBREVIATIONS 92

APPENDIX D - COUNTRY CODES 93

APPENDIXE - INSTRUCTIONS FOR COMPLETING AWARDEE NAMES

APPENDIX F - HISTORY BLACK COLLEGES AND UNIVERSITIES

MINORITY INSTITUTIONS 107

- APPENDIX G - INITIATING OFFICES 


\author{
HANDBOOK \\ FOR \\ PREPARATION OF \\ INDIVIDUAL PROCUREMENT ACTION REPORT (IPAR)
}

\title{
INTRODUCTION
}

The Procurement and Assistance Data System (PADS) provides a mechanism for collectirg, assembling, organizing, and presenting acquisition and assistance data for the Department of Energy (DOE). This handbook and associated documents establish a unlform system to report acquisition/assistance data to PADS for the collection, processing, and dissemination of official statistical data on the Department's acquisition and assistance actions. The data provides, based on information available at the time of request, a basis for any recurring and special reports to the senior procurement executive, Congress, General Accounting Office (GAO), Federal executive agencies, Office of Management and Budget (OMB), and the general public. It provides information for measuring and assessing the extent to which small business firms and small disadvantaged business enterprises are sharing in DOE placement, and for other acquisition and assistance policy and management control purposes.

\section{GENERAL INFORMATION}

The Individual Procurement Action Report consists of two data collection forms, one for collecting information on procurement actions (DOE F 4200.40) and another for collecting information on financial assistance actions (DOE F 4200.40A). The IPAR Supplement (DOE F 4200.41) may be used for data collection on both types of actions.

The Handbook for the Preparation of the Individual Procurement Action Report (IPAR) has been designed in two sections; Procurement and Financial Assistance to support the individual forms.

Requirements

In accordance with the instruction set forth in the DOE Order 1331.1D, dated 5-18-92, entitled "Procurement and Assistance Data System," awarding office managers are responsible for collection and submission of data to PADS on the receiptlacceptance of procurement requests, and the award/modification of procurement and financial assistance actions. This includes contract adrinistration from execution of an award (acceptance) through award completion, closeout and retirement. All data shall be submifted to PADS within five (5) working days after the action date. 


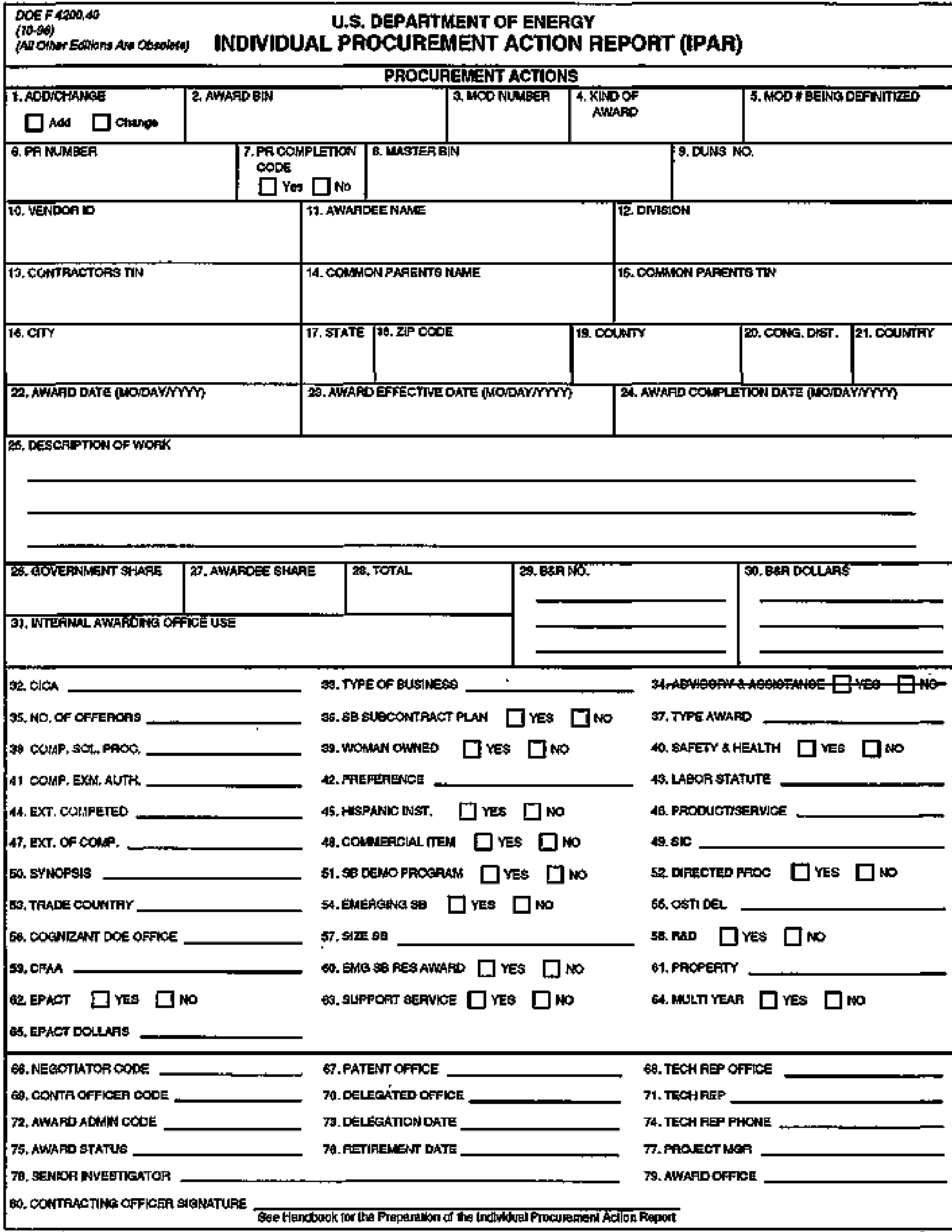


DOE F 4ROCLAOA

(Na.es)

U.S. DEPARTMENT OF ENERGY

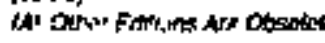

INDNIDUAL PROCUREMENT ACTION REPORT (IPAR)

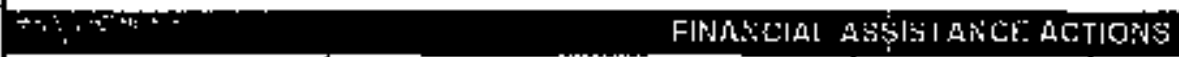

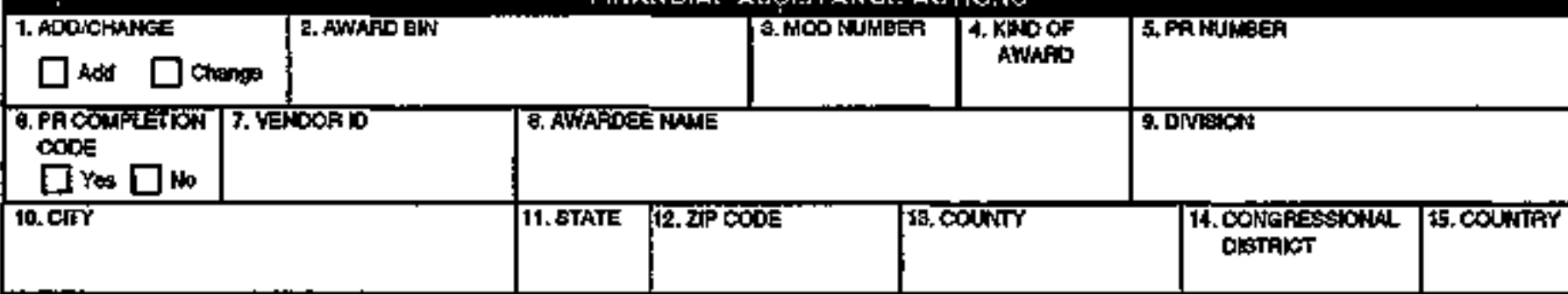

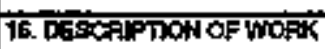

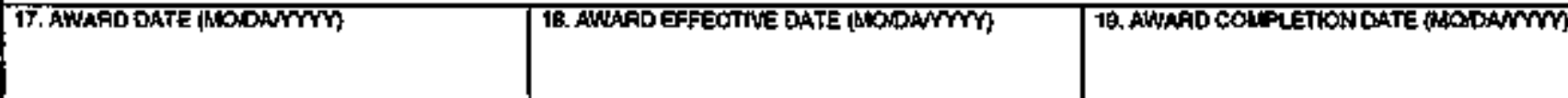

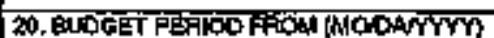

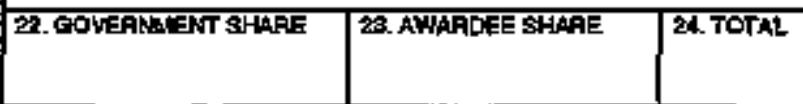

27. INT EATAL AWAFEIFG OFFICE WEF

28. CFOANO.

30. STATE APPLOATION ID

\%2. STATE

34. COUNTY

38. TYPE OF AWAFE

38. WTI DeDNERAgLE

49. RESEAFCH ANO DEVELOFIENT $\square$ YeS $\square$ Mo

12. HISPANac InSTITIRON $\square$ Yes $\square$ wo

44. BSALLEUS. TECH, TRANSFFER $\square$ YES $\square$ MO

46. CFAA

4Q. CONTRACTIKS OFFCER COJE

50. AWAPOSTATUS

52. DELLEBATED OFFICE

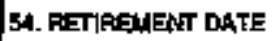

5G, TECH. FEP. MUUE

58. PRONECT MANUEER

OO. SENIOP WNESTKKKTOR
21 QUDXET PEROD TO ONODAYYY)

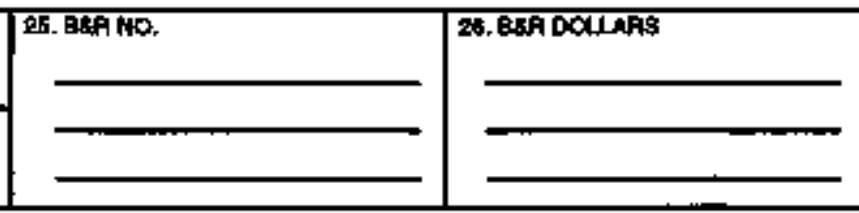

29. CATEBORY OF BOAROHER

a1. CrTy

9. Z1P CODE

S. CONCRESGIONAL DISTAICT

S7. EXTENT OF CONFETION

as. TYPE OF BUSANDSS

41. GONEHAMEINT PROPERTY

4.5819 $\square$ res $\square$ to

43. COENIZANT DCE OFFLE

47. NEGOTLROR CODE

49. AWAROADMNISTRATON COOE

51. PATENT OFFICE

59. DELLGATIONDATE

S5. TECH. REP. OFFIEE

БI. TESH, REP.PHONE

59. AWAFDING OFFICE

B1. CONTRACTNG OFFICER StGMATUFE

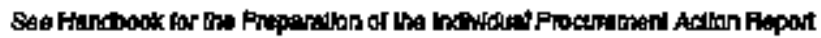




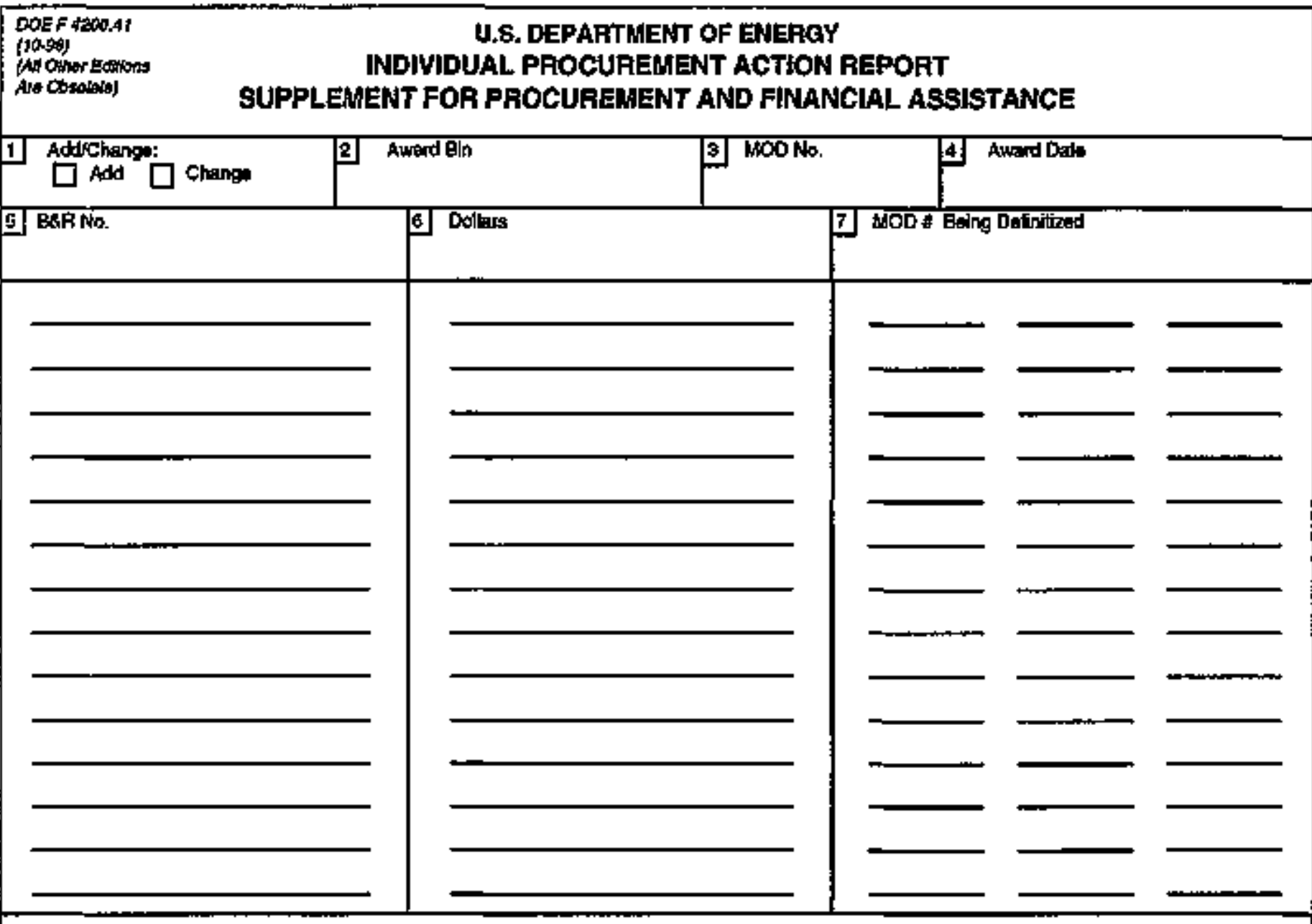

FIELD OFFICE ENTRY FIELOS

B. DATE (MMDONYMY)

9. DOLAAS

10, TEXT

11. NUMEFIC

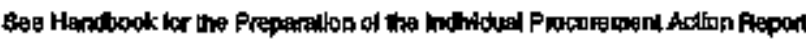




\section{IIEM 1 ADP/CHANGE}

Check "ADD" if this is a new basic award or a modification (to an existing award) not previously reported to PADS. Check the block marked "CHANGE" if this award action is a change to an award/modification previously reported to PADS.

\section{ITEM 2 AWARD BIN (BUSINESS INSTRUMENT NUMBER)}

Enter the identifying number to the legal document which constitutes the agreement between the Department of Energy and the awardee.

Reference DOE Order 1331.2B, "Departmental Business Instrument Numbering System," dated 5-18-92:

Award Business Instrument Number The award business instrument number consists of 17 characters and has the following format: DE-AC01-95FE12345. Information is encoded in the number as follows:

(1) The first and second positions, DE-AC01-95FE12345, contain the two-character code assigned by the Federal Procurement Data Center to identify Department of Energy awards.

(2) The third position contains a dash.

(3) The fourth and fifth positions, DE-ACO1-95FE12345, contain a two-character code corresponding to the type of award instrument. (The Type of Award Instrument Codes and definitions follow on pages 5 through 10. .)

(4) The sixth and seventh positions, DE-AC01-95FE12345, identify the responsible awarding office. (The Awarding Office codes follow on page 4 .)

(5) The eighth position is a dash.

(6) The ninth and tenth positions, DE-AC01-95FE12345, contain the last two digits of the fiscal year of the award date of the basic award.

(7) The eleventh and twelith positions, DE-AC01-85FE12345, contain a two-character code indicating the initiating office (For Initiating Office Codes see Appendix G). (Due to Departmental reorganizations, some award business instrument numbers exist that contain codes that are no longer used for new awards.)

(8) The thirteenth through seventeenth positions, DE-AC01-95FE12345, will contain a five digit serial number assigned by the inttiating office.

The last seven digits of the award BIN is referred to as the Register Number. This number remains unchanged from initiation through retirement. 


\section{AWARDING OFFICE}

01 Washingtion Procurement Operations Office

02 Chicago Operations Office

03 Oakland Operations Office

04 Albuquerque Operations Office

05 Oak Ridge Operations Office

06 Richland Operations Office

07 Idaho Operations Office

08 Nevada Operations Office

09 Savannah River Operations Office

11 Pittsburgh Naval Reactors Office

12 Schenectady Naval Reactors Office

13 Grand Junction Project Office

16 Portsmouth Project Office

17 Environmental Measurements Laborakory

19 Bartlesville Project Office

21 Morgantown Energy Technology Center

22 Pittsburgh Energy Technology Center

23 Fernald Area Office

24 Ohio Field Office

32 Los Alamos Area Office

33 Kansas City Area Office

34 Rocky Flats Office

36 Golden Field Office

41 Boston Support Office

43 Philadelphia Support Office

44 Atlanta Support Office

45 Chicago Support Office

48 Denver Support Office

51 Richland Support Office

65 Westem Area Power Administration

70 Southeastern Power Administration

75 Southwestem Power Administration

85 Alaska Power Administration

91 Naval Petroleum and Oil Shale Reserves

92 California Naval Petroleum

96 Strategic Petroleum Reserve Office 
TYPE AWARD INSTRUMENT

$\begin{array}{ll}\text { AA } & \text { Basic Agreement (Terms and Conditions Only) } \\ \text { AB } & \text { Blanket Purchase Agreement } \\ \text { AC } & \text { Contract } \\ \text { AD } & \text { Delivery Order } \\ \text { AF } & \text { Simplified Acquisition Procedure over } \$ 25,000 \\ \text { AI } & \text { Interagency Agreement (Purchase) } \\ \text { AK } & \text { Basic Ordering Agreement } \\ \text { AM } & \text { Indefinite-Delivery Contract } \\ \text { AP } & \text { Simplified Acquisition Procedure under } \$ 25,000 \\ \text { AR } & \text { Research Opportunity Award } \\ \text { AS } & \text { Special Research Contract. } \\ \text { AT } & \text { Task Order } \\ \text { AX } & \text { Simplified Acquisition for SB Competitiveness Demonstration Program } \\ \text { CR } & \text { Waste Management Revenue Collection } \\ \text { GI } & \text { International Agreement } \\ \text { GM } & \text { Memorandum of Understanding } \\ \text { RL. } & \text { Lease of Real Property } \\ \text { RO } & \text { Other Real Property Transaction } \\ \text { RP } & \text { Purchase of Real Property } \\ \text { SA } & \text { Interagency Agreement (Sales) } \\ \text { SC } & \text { Sales Contract } \\ \text { UN } & \text { UNICOR (Federal Frison Industries) }\end{array}$ 


\section{CODE DEFINITION}

AA Basic Agreement (Terms and Conditions Only)

A basic agreement is a written instrument of understanding, negotiated between an agency or contracting activity and a contractor, that (1) contains contract clauses applying to future contracts between the parties during its term and (2) contemplates separate confracts that will incorporate by reference or attachment the required and applicable clauses agreed upon in the basic agreement. A basic agreement is not a contract. (FAR 16.702)

AB Blanket Purchiose Agreement

A blanket purchase agreement (BPA) is a simplified method of filling anticipated repetitive needs for supplies or services by establishing "charge accounts" with qualified sources of supply. (FAR 13.201)

AC Contract

A mutually binding legal relationship obligating the seller to furnish the supplies or services (including construction) and the buyer to pay for them. It includes all types of commitments that obligate the Government to an expendituse of appropriated funds and that, except as otherwise authorized, are in writing. (FAR 2.1)

AD Delivery Order

An order for supplies or services placed against an established contract or with Government sources of supply. (FAR 13.101) (Item 8 Master Bin must be entered when $A D$ is usod.)

AF Simplified Acquisition Procedure over $\$ 25,000$

An award made under FAR 13, Simplified Acquisition Procedures, where the total value of the award is from $\$ 25,001$ to $\$ 100,000$.

Al Interagency Agreement (Purchase)

A procedure by which an agency needing supplies or services (the requesting agency) obtains them from another agency (the servicing agency). (FAR 17.501)

Basic Ordering Agreement

A basic ordering agreement is a written instrument of understanding, negotiated between an agency, contracting activity, or contracting office and a contractor that contains: (1) terms and clauses applying to future contracts (orders) beiween the parties during its term; (2) a description, as specific as practicable, of supplies or services to be provided; and (3) methods for pricing, issuing, and delivering future orders under the basic ordering agreement. A basic ordering agreement is not a contract. (FAR 16.703) 
Definite-Quantity Contract

A definite-quantity contract provides for delivery of a definite quantity of specific supplies or services for a fixed period, with deliveries to be scheduled at designated locations upon order. (FAR 16.502)

Requirements Contract

A requirements contract provides for filling all actual purchase requirements of designated Government acivities for specific supplies or services during a specified contract period, with deliveries to be scheduled by placing orders with the contractor. (FAR 16.503)

Indefinite-Quantitv Contract

An indefinite-quantity contract.provides for an indefinite quantity, within stated limits, of specific supplies or services to be furnished during a fixed period, with deliveries to be scheduled by placing orders with the contractor. (FAR 16.504)

AP Simplified Acqusisition Procedure under $\$ 25,001$

An offer by government to buy certain supplies or nonpersonal services and construction from commercial sources, upon specified terms and conditions, the aggregate amount of which does not exceed $\$ 25,000$. (FAR 13)

AR Research Opportunity Award

A contract for research solicited from a Research Opportunity Announcement. (FAR 35.016)

AS Specia| Research Contract

Headquarters designated acquisition award instrument for basic research with educational or other nomprofit institutions when the ennual DOE support under the contract does not exced $\$ 1,000,000$ per year. DOE's monetary obligation should be a specified amount referred to as the support ceiling, effective for the contract term.

AT

Task Order

The purchase of supplies or services where the place of delivery and quantity, or performance of services, are specified in each order. (Item 8 Master Bin must be entered when AT is used.)

AX Simplified Acquisition for Small Business Competitiveness Demonstration Program A simplifted acquisition that fits in the designated industry groups as defined by Business Opportunity Development Reform Act of 1988 (Public Law 100-656) or into the ten targeted industry categories as defined by Department of Energy Office of Small and Disadvantaged Business Utilization. 
CR Waste Management Revenue Collection

A contract for the "funds in" collection of revenue from contractors of the Department on disposal of spent nuclear fuel and/or high level radioactive waste. (No dollars entered on IPAR.)

GI

International Agreement

Treaties and other agreements of a contractual character between different countries or organizations of states (foreign) creating legal rights and obligations between the parties.

GM Memorandum of Understanding

A written agresment broadly stating basic understanding and describing a mechanism for coordinating activities to be engaged in by the Department and other signatory authorities. It is not limited to understandings with Federal agencies but may include: local, State, intemational, and other government entities; the private sector, and educational institutions. (No funds agreement.)

RL Lease of Real Property

An agreement which gives exclusive possessory interest in the property for a specified time reserving to the owner rent. (Rental property is land or land and improvements including interests therein.)

RO Other Real Property Transaction

Real property actions that are not lease or purchase of real property.

RP Purchase of Real Property

The purchases of real property. (Real property is land or land and improvements including interests therein.)

SA Interagency Agreement (Sales)

A sales type award (funds in) between DOE and another executive agency which sets out specific tasks to be accomplisted by DOE in support of the other agency. As a sales instrument, it is intended to transfer some personal property or nonpersonal service to the buying agency for appropriate remuneration. The agreement clearly specifies work contemplated, reporting requirements, procurement and patent policy, personnel exchanges (if necessary), and arrangements for transfer of funds (when applicable). (No dollars entered in PADS.)

SC Sales Contract

A contract under which a purchaser buys Government-owned material from the Govemment (No dollars entered in PADS.) 
An award made to Federal Prison Industries as a new basic award or an order against another contract (i.e., Federal Schedule)

\section{ITEM 3 MODIFICATION NUMBER}

Award Modification Number. All new basic awards and modifications to an award are identified by a modification number assigned by the awarding office. These modification numbers are not part of the award business instrument number.

(1) The basic award and modifications to each business instrument shall be sequentially numbered by use of a four-position alphanumeric code.

(a) The first position shall be a capital letter identifying the type of action as follows:

A (Amount) An action adding, changing, or deleting financial data that is collected on the IPAR, but not administrative corrections to financial data.

M - (Miscellaneous) An action having no net effect on financial data that is collected on the IPAR, including administrative corrections.

(b) The second through fourth positions shall contain a sequential serial number of the madification. For basic awards, enter 000 . The next assigned modification number would be 001,002 etc. These numbers continue in sequence throughout the life of the award.

(2) Examples of modifications:

(a) M001 - first modification to contract, no effect on financial data in this example since it is a miscellaneous mod.

(b) A002 - second modification to contract, changes in financial data in this example since it is an amount mod.

(c) M003 - third modification to contract, no effect on financial data in this example since it also a miscellaneous mod.

\section{ITEM4 KIND OF AWARD ACTION}

Enter the 2-character code which identifies the appropriate action taken. 


\section{CODE DESCRIPTION - New Awards}

1A New Definitive Award

1G Order Under Single Award Contract

$1 J$ Order Under Federal Schedule

1K Order Under Basic Ordering Agreement (BOA)

$1 \mathrm{~L} \quad$ Order Under DOE Interagency Agreement

12 Order under Multiple Award Contract

LC Letter Contract

SP Simplified Acquisition Procedure

CODE DESCRIPTION-Modifications

1D Exercise of Option

1J

$1 \mathrm{M}$

$1 \mathrm{~N}$

IP

1T

IV

IW

Modification to Order Under Federal Schedule

Termination for Default

Termination for Convenience

গX

$1 Y$

Supplemental Agreement - Monetary Action

Incremental Funding (Only)

No Cost Time Extension (Only)

Adrninistrative Change

BC

Funding Adjustment to Completed Award

Other

DM

Bilateral Change Order

LM

Definitizing Modification

NW

TR

L.etter Modffication to a Definitized Contract

UC

New Work (Outside Scope)

Transferred Award

Unilateral Change Order

CODE DEFINITION

\section{NEW AWARDS}

New Definitive Award

The establishment of a binding legel relationship between the Government and awardee, or contractor, for the purpose of receiving supplies, services, construction, research and development.

$1 \mathrm{G} \quad$ Order Under Single Award Contract

An order issued under a single award indefinite delivery indefinite quantity (IDIQ) contract.

$1 \mathrm{~J} \quad$ Order Under Federal Schedule

An order for supplies and/or services against an established Federal schedule contract. The terms and conditions, including price and delivery, are included in the Federal schedule. 
An order for supplies and/or services under a basic ordering agreement.

1L Order Under DOE Interagency Agreement

The purchase of supplies or services under a DOE Interagency or Intemational Agreement.

12

Order Under Multiple Award Contract

An order under a multiple award indefinite delivery indefinite quantity (IDIQ) contract pursuant to FAR 16.504(c)(1) or 16.504(c)(2).

LC Lefter Contract

A written prelirninary contractual instrument in which the terms and conditions were not defintized prior to execution of the award.

SP Simplified Acquisition Procedure

The procurement of supplies andior nonpersonal services pursuant to procedures in FAR Part 13.

\section{MODIFICATIONS}

$1 D \quad$ Exercise of Option

"Option" is a unilateral right in a contract by which, for a specified time, the Government may elect to purchase additional supplies or services called for by the contract or may elect to extend the term of the contract. (FAR 17.201) Written notification via contract modification within the time specified in the contract is required to exercise the option.

1J Modification to Order Under Federal Schedule

A modification to an order for supplies and/or services against an established Federal schedule contract.

Termination for Default

The exercise of the Government's contractual right to completely or partially terminate a contract because of the contractor's actual or anticipated failure to perform its contractual obligations. (FAR 49.4)

1N Termination for Conveniences

The exercise of the unilateral right of the Government to terminate, in whole or in part, the contractor's performance under a contract when the contracting officer determines that it is in the best interest of the Government. (FAR 49.1) 
A contract modification to an award effecting changes in the general scope of work, obligations, or other award terms and conditions. This type of modification should require the signature of the contractor and the contracting officer. (FAR 43.101)

it Incremental Funding (Oniv)

The obligation of funds to an award containing a total price or estimated cost, in periodic installinents against prescribed periormance goals or objectives. The modification is nomally unilateral with an increase in obligations only.

IV No Cost Time Extension (Only)

A modification which extends only the performance period under an award with no increase in the total face valus or obligated dollars.

Administratjve Change

A unilateral modification to an award instrument which changes administrative data; e.g., paying office, technical representative, etc. (FAR 43.101)

$1 \mathrm{~F} \quad$ Funding Adjustment to Completed Award

A modification issued to an award instrument which has been completed wherein funds need to be obligated or deobligated before it can be retired.

Other

"Catch all" code used to report modification actions which did not meet the criteria of the other codes.

BC

Bilateral Change Order

A supplemental agreement issued pursuant to the changes clause in which the terms of the resulting equitable adjustment to the contract were negotiated prior to issuance of the instant change order.

DM Definitizing Modification

A supplemental agreement issued to definitize one or more unilateral change order, letter modification to a definitized contract andfor a letter contract.

LM Letter Modification to a Definitized Contract

A bilateral modification incorporating new work into the contract in which the terms and conditions of the modification were not definitized prior to the exectution of the modification. (Do not use against undefinitized contract.) 
A supplemental agreement which incorporates work outside the scope of the original contract into the contract.

TR

\section{Transferred Award}

A contract award that is being transferred from one awarding office to another. The office transferring the award is responsible for transfer modifications.

UC Unilateral Change Order

A unilateral modification issued pursuant to the changes clause in which the terms of the resulting equitable adjustment to the contract were not definitized prior to the issuance of the instant change order.

ITEM 5 MOD NUMBER BEING DEFINITIZED

Enter the modification number (A--or $M--)$ being definitized that was previously awarded as an undefinitized action, a unilateral change order, letter modification, or letter contract.

If this award action definitizes more than one modification, enter all modifications that are being definitized by this one action. If additionat space is required, see DOE Form 4200.41, Item 7.

\section{ITEM 6 PROCUREMENT REQUEST NUMBER}

A. Enter the 16-character number of the PR that authorized this award (e.g., 01.95FE12345.000) from block 3 of the DOE Form 4200.33.

B. This number is also found in block 3, Requisition/Purchase Request No. on the Standard Form 26, Award/Contrack, and on Standard Form 30, Modification.

C. The basic portion of a procurement request number is twelve characters long in a format exemplified by 01-95FE12345. This is identical to the last 12 characters of the award business instrument number, with the following exception: for a procurement request number, the fiscal year portion reflects the fiscal year of the anticipated award date. For example, the basic portion of a procurement request number which initiated a procurement action for a new award in FY 1995 would be in the form of 01-95FE12345. Subsequent actions in FY 1995 would have the same basic portion for their procurement request numbers. For actions related to this award in FY 1986, the procurement request number would be in the form of 01-96FE12345. 
With regard to the award business instrument number, however, the fiscal year portion of this number remains the same as the year in which the instrument was initially awarded, in this example, FY 1995. Therefore, regardless of the fiscal year of the procurement request, the fiscal year portion of the award business instrument number does not change.

The supplementary portion of the procurement request number consists of a decimal point followed by a three-digit number added to the right of the basic portion of the procurement request number. The number identifies the sequence of procurement requests initiated for a fiscal year. The number is assigned sequentially starting with "000" and is used to represent funding actions or any other action that involves procurement activity; e.g., a no-cost extension.

To continue with the previous example, the procurement request nurnber that initiated the basic award would be 01-95FE12345.000. The next action in FY 1995 would be a modification with a procurement request number 01-95FE12345.001. This supplemental portion does not become pert of the award business instrument. Each fiscal year a new sequence begins with "001." The "000" is used only once during the life of the award.

Sometumes the awarding office will initiate a modification action under an award where the initiating office need not issue a procurement request. To provide for this case, the three-character sequence has been divided to have the awarding office use "501" through "599". If, in the above example, the awarding office were to initiate its own first procurement request under award in FY 1995 to change the cognizant contracting officer, it would be coded as 01-95FE12345.501.

The use of a different series prevents duplication of procurement request numbers that might ocur when two separate offices are issuing procurement requests.

The following examples further explain the supplementary portion of the procurement request number:

01-95FE12345.000 - New award initiation.

01-95FE12345.001 - First subsequent action in FY 1995.

01-96FE12345.001 - First subsecquent action FY 1996.

01-96FE12345.002 - Second subsequent action in FY 1996.

01-96FE12345.501 - First awarding office action.

D. There are four types of processing which do not require a procurement request number in order to process an award. They are AN-NOPR, WPAS-NOPR, UTIL-NOPR, and PRFY-NOPR. (See PADS System Reference Manual for additional information) 


\section{AN-NOPR Processing}

This is the procedure in some awarding offices to award zero dollar mods to a contract without entering any Procurement Request forms. This process may be used for cument year actions only. The following step is necessary to process AN-NOPR transactions.

Fill out an IPAR form with a Mod Number (item 3) beginning with " $M$ " and followed by a mod number greater than " 000 " that has not been used previously for that contract. No financial infomation is allowed on this action. The PR Number (ltem 6) must contain AN-NOPR to identify this type of action.

2. WPAS-NOPR Processing

WPAS-NOPR processing may only be used to report award actions against contracts whose funding is controlled through the Work Authorization System (WAS). It is unique in that funds are not committed through the use of Procurement Requests (PR's). In order to use the WPAS-NOPR process in PADS, the contract cited in the Award Bin (Item 2) must be designated as a WAS contract.

The initial new award for a WAS contract must have been previously reported to PADS through the use of normal PR processing.

Fill out an IPAR as follows: The Mod number (Item 3) must be greater than "000"; the PR Number (ltem 6) must contain WPAS-NOPR.

\section{UTIL-NOPR Processing}

UTIL-NOPR processing is used to report, as contract mods, payments made for the purchase of power and other utilities from specified utility contractors.

Procurement Requests may not necesserily be used to commit funds for the utilities in these cases. Instead, as invoices are received on a regular besis from the utility, these invoices are paid and the payments reported to PADS using the IPAR. To use the UTIL-NOPR'process to report invoice payments into PADS, the contract cited in the Award BIN (Item 2) must be designated as a utility contract in PADS miscellaneous table UTIL.

Fill out an IPAR as follows: The first position of the Mod number(ltem 3) must contain an "A"; the second through fourth positions of the mod must contain " 500 " for the first mod reporting a utility payment. Continue using consecutively higher numbers to "999" for all future mods of this type. This is done so that these special mods may be differentiated from the standard mods to the basic utility contract itself. The PR Number (ltem 6) must contain UTLL-NOPR.

4. PRFY-NOPR Pracessing 
PRFY-NOPR processing is used to report awards from previous fiscal years. This special process is allowed so actions that have not been entered due to oversight do not require the entry of a PR.

Enter PRFY-NOPR in Item 6 on the IPAR. This may be used for new awards and modifications from previous fiscal years.

\section{ITEM $7 \quad$ PR COMPLETION CODE}

Check the block indicating whether the PR referenced in ltem 6 is completed or stils open for further action.

\section{CODE DESCRIPTION}

YES The PR is completed by this action.

NO The PR is not completed by this action and will be used again.

\section{ITEM 8 MASTER BIN}

Enter the 17-character DOE Master Award BIN or another agency's contract number (e.g., GSA Federal Supply Schedule Contract).

This number is used when a separate award BIN is created to issue a delivery order or task order for actual delivery of products or services. (Examples: DE-AM01-96AD12345, GS-99X9999). DOE Master Bin numbers begin with DE-Al, DE-AK, DE-AM, or DE-GI. For orders against other agencies, see miscellaneous table AWAG, Awarding Agency.

When GSA number has alpha "OO" in the 3rd and 4th position, enter as numeric 00 .

GSA schedule numbers will be verified for accuracy with numbers provided by GSA.

ITEM9 DUNS NUMBER (Data Universal Numbering System)

Enter the 9-character DUNS number identifying the business establishment or individual receiving the award. The DUNS number relates to the principal place of performance of the award.

This number can be obtained (When not in contract file) by celling Dun and Bradstreet, Inc. at 1-610-882-7741. Facsimile requests should be made to $1-610-882-7140$.

The DUNS number for UNICOR is 626627459 .

The DUNS number will be edited for accuracy. 
(DUNS number is not allowed on interagency agreements, simplified acquisition under $\$ 25,001$ (AP), sales, basic agreements (terms and conditions), memorandum of understanding (MOU), and international agreements.)

\section{ITEM 10 VENDOR ID}

Enter the 13-character Vendor ID code for the contractor and division. The Vendor ID codes can be found in the Directory of Awardee Names, DOE/OSTI-4637, issued by the Office of Scientific and Technical Information (OSTI) in Oak Ridge, Tennessee. The Vendor ID in the Directory must match the name, division (if applicable), cliy, and state of the awardee.

If no Vendor ID code is listed in the Directory for the exact name, division (if applicable), city and state of the awardee, the awardee name (Item 11) must be entered, and division (Item 12) if applicable, in accordance with the Instructions for Completing Awardee Names in PADS, Appendix $E$ to this handbook.

\section{ITEM 11 AWARDEE NAME}

Enter the contractor name (up to 30 characters) of the individual, partnership, corporation, firm, association, Federal, State, or local agency, or other type of awardee of the new award. Formatting abbreviations are to be in accordance with Instructions for Cornpleting Awardee Names in PADS, Appendix E. (Systern-generated if Item 10 is entered.)

\section{ITEM 12 DNISION}

Enter the name of the suborganization of the contractor in ltem 11 above, Awardee Name.

Example: Cable Division (System generated if Item 10 is entered.)

ITEM13 CONTRACTOR'S TIN

Enter the 9-digit taxpeyer identification number (TIN) for the contractor receiving the award. 
Contractor's TIN is required for all new basic contract awards except the following: GSA Federal Supply Schedule Awards; awards to State/local governiments; any contract with a foreign government (or any agency or instrumentality thereof); foreign corporation, of foreign partnership that does not have income effectively connected with the conduct of a trade or business in the U.S. and does not have an office or place of business or a fiscal or paying agent in the U.S.

ITEM 14 COMMON PARENT'S NAME

Enter the name of the common parent of the affiliated group if the contractor receiving the award is a member of an affiliated group of corporations that files its Federal income tax returns on a consolidated basis. Leave blank if not applicable.

\section{ITEM15 COMMON PARENT'S TIN}

Enter the taxpayer identification number (TIN) of the common parent of the affiliated group if the contractor receiving the award is a member of an affiliated group of corporations that files its Federal income tax returns on a consolidated basis. Required if Item 14 is completed; otherwise leave blank.

\section{PRINCIPAL PLACE OF PERFORMANCE}

Report the city, state, foreign country, or Govemment installation where the items will be produced, manufactured, mined, or grown or where the service will be performed. This item refers to the contractor's final manufacturing assembly point, processing plant, construction site, place where a service is performed, location of mines, or where the product is grown.

If the items are supplied parts shipped from stock by a regular dealer, the place of performance is the regular dealer's location. If the items are shipped for the regular dealer by a subcontractor who produces the items, the place of performance is the subcontractor's location.

If more than one location is involved, report only the location involving the largest dollar sthare of the contract.

For construction and architectengineer contracts, report the construction site location. If the contract is for architectengineer design work, the place of performance is where the design work is being done.

If the place of performance cannot be determined le.q. if the contractor has multiple location sites perfoming the same volume of work) or commercial item acquisition procedures were used, report the contractor's billing or home office location. 
ITEM $16 \quad \underline{\text { CITY }}$

Enter the name of the city that is the principal place of performance of the award (up to 25 characters). (Example: Daljas).

\section{$\underline{\text { ITEM } 17}$ STATE}

Enter the 2-character U.S. Postal Service code for the state or outlying area that is the principal place of performance of the award. See Appendix $\mathrm{C}$ for codes.

\section{ITEM 18 ZIP CODE}

Enter the 9-digit zip code that applies to the principal place of performance of the award. (Example: 22134-2700)

Zip Codes are listed in the U.S. Postal Service's National Zip Code Directory.

For locations outside the U.S., leave zip code blank.

\section{ITEM19 COUNTY}

Enter the name of the county that is the location of the principal place of performance of the award. (Example: Montgomery). For the District of Columbia (DC), and locations outside the U.S., leave county blank.

If city, state, and zip code are entered, county will be system generated. If city within the state is in multiple counties, or if multiple cities with the same name are in a state, county must be entered.

The FIPS 55 (Federal Information Processing Standards) provides information concerning city, county, and state.

\section{ITEM 20 CONGRESSIONAL DISTRICT}

Enter the 2-character numeric code for the congressional district that is the principal place of performance of the awato. These codes are listed in the Congressional District Aflas. (Example: 01)

\section{ITEM21 COUNTRY}

Enter the 2-cheracter code for the country that is the principal place of performance of the award. For locations in the U.S., leave this element blank. See Appendix D for country codes. 


\section{IIEM 22 AWARD DATE}

Enter the date the DOE contracting officer signed the official award or modification. (Format: (MMDDMMY).

\section{ITEM 23 AWARD EFFECTIVE DATE}

Enter the date the award becomes effective. This date reflects the beginning of the period of performance and can be found in block 2 of the Standard Form 30 and Standard Form 26. (Format: MM/DDMMY)

\section{ITEM 24 AWARD COMPLETION DATE}

Enter the completion date of the award. This field must be filled out for all time extensions to the basic award. (Format: MM/DDMYYY)

\section{ITEM 25 DESCRIPTION OF WORK}

Enter the briff description from the statement of work or project description (not less than 15 charecters). A maximum of 150 characters (including spaces, dashes, etc.) may be entered. Insure that description is a concise statement of what is acquired or what work is being performed. Avoid use of abbreviations, acronyms and jargon if possible.

\section{FINANCIAL DATA GUIDANCE:}

a. For a "funds in" or sales transaction, government share, awardee share and total are nof entered into PADS.

b. Dollars are entered as whole dollars, no cents, no decimals, no commas.

c. Decreases in dollars should be preceded by a minus "-". (Example: $-25000)$.

d. Corrections to previously entered financial data on modifications will replace current dollar values. Changes may be made by. any of three methods:

Government share, awardee share. and total (Items 26, 27 and 28). A change to any one of these fields requires re-entry of data in all three. To leave dollars as they are on the data base, the same values must be re-entered.

If B\&R numbers and B\&R dollars (Items 29 and 30) are not entered, they will be left as they currently exist on the data base. 
B\&R numbers and/or B\&\&R doilers (ltems 29 and 30). A change made to any B\&R number or B\&R dollar amount requires re-entry of all $B \& R$ numbers and their corresponding $B \& R$ dollars.

If govemment share, awardee share, and total (ltern 26, 27 and 28) are not entered, they will remain as they currently exist on the data base.

All five fields government share, awardee share, total, B\&R number, and B\&R dollars (items $26,27,28,29$ and 30 ).

ITEM 26 GOVERNMENT SHARE (DOE Face Value)

For the basic award, enter the total dollar amount of DOE's share of the award amount. For a modification, enter the amount of increase or decrease to the current value. PADS will calculate the resultant value.

NOTE:

Government Share for Contracts with Options excludes amounts associated with unexercised options.

Government Share for Letter Confracts is the estimated value of the definitized contract.

Govemment Share for Management and Operating contracts is the estimated value for the period of performance when first awarded or when extended.

Initial "000" Award

\begin{tabular}{|c|c|c|c|c|}
\hline $\begin{array}{c}\text { 26. Government Share } \\
500,000\end{array}$ & 27. Awardes Share & $\begin{array}{c}28 . \text { Total } \\
500,000\end{array}$ & $\begin{array}{c}\text { 29. B\&R No. } \\
\text { AA01 }\end{array}$ & $\begin{array}{c}\text { 30. B\&R Dollars } \\
200,000\end{array}$ \\
\hline
\end{tabular}

Contract action awarded for a 3-year period for a total estimated cost to the Government of $\$ 500,000$. Funds obligated at the time of initial award $\$ 200,000$. There is no awardee share.

\begin{tabular}{|c|c|c|c|c|}
\hline $\begin{array}{c}\text { 26. Govemment Share } \\
300,000\end{array}$ & 27. Awardee Share & $\begin{array}{c}28 . \text { Total } \\
300,000\end{array}$ & $\begin{array}{c}\text { 29. B\&R No. } \\
\text { AA01 }\end{array}$ & $\begin{array}{c}\text { 30. B\&R Dollars } \\
300,000\end{array}$ \\
\hline
\end{tabular}

Contract action awarded for a 3-year period for a total estimated cost to the Government of $\$ 300,000$. Funds obligated at the time of initial award is full funding of $\$ 300,000$. There is no awardee share. 
Madification - Mad Greater than " 000 "

\begin{tabular}{|l|l|l|c|c|}
\hline 26. Govemment share & 27. Awardee Share & 28. Total & $\begin{array}{c}\text { 29. B\&R No. } \\
\text { AA01 }\end{array}$ & $\begin{array}{c}\text { 30. B\&R Dollars } \\
100,000\end{array}$ \\
\hline
\end{tabular}

The contract action was initially executed for $\$ 500,000$; obligated dollars were $\$ 200,000$. (See previous example) An incremental funding modification is awarded for $\$ 100,000$. This action has no effect on the Government share of the award; therefore, Item 26 is left blank.

\begin{tabular}{|c|c|c|c|c|}
\hline $\begin{array}{l}\text { 26. Government Share } \\
50,000\end{array}$ & 27. Awardee Share & $\begin{array}{c}\text { 28. Total } \\
50,000\end{array}$ & $\begin{array}{c}\text { 29. B\&R No. } \\
\text { AA01 }\end{array}$ & $\begin{array}{c}\text { 30. B\&R Dolars } \\
50,000\end{array}$ \\
\hline
\end{tabular}

The contract action was initially executed for $\$ 300,000$; obligated dotlars were $\$ 300,000$. An increase in scope modification is awarded for $\$ 50,000$, and dollars obligated for the mod is $\$ 50,000$. Item 26 is filled in with $\$ 50,000$ because of an increase of the Government share.

\section{IIEM 27 AWARDEE SHARE}

For the basic awatd, enter the total dollar amount of the awardee's share of the award amount, if none, leave blank. For a modification, enter the amount of increase or decrease to the current awardee share value. PADS will calculate the resultent value.

Initial " 000 " Award

\begin{tabular}{|c|c|c|c|c|}
\hline $\begin{array}{l}\text { 26. Government Share } \\
\mathbf{2 5 0 , 0 0 0}\end{array}$ & $\begin{array}{l}\text { 27. Awardee Share } \\
75,000\end{array}$ & $\begin{array}{l}\text { 28. Total } \\
325,000\end{array}$ & $\begin{array}{l}\text { 29. B\&R No. } \\
\text { AA01 }\end{array}$ & $\begin{array}{l}\text { 30. B\&R Dolars } \\
100,000\end{array}$ \\
\hline
\end{tabular}

An action awarded for a 3-year period for a total estimated cost to the Government of $\$ 250,000$, a total estimated cost to the awardee of $\$ 75,000$, and the Government funds obligated at time of awaro are $\$ 100,000$. The totai estimated cost of the award is $\$ 325,000$.

\begin{tabular}{|c|c|c|c|c|}
\hline $\begin{array}{l}\text { 26. Govemunent Share } \\
400,000\end{array}$ & $\begin{array}{l}\text { 27. Awardee share } \\
25,000\end{array}$ & $\begin{array}{l}\text { 28. Total } \\
425,0000\end{array}$ & $\begin{array}{l}\text { 29. B\&R No. } \\
\text { AAO1 }\end{array}$ & $\begin{array}{l}\text { 30. B\&R Dollars } \\
400,000\end{array}$ \\
\hline
\end{tabular}

An action awarded for a 3-year period for a total estimated cost to the Government of $\$ 400,000$, a total estimated cost to the awardee of $\$ 25,000$ and the funds obligated of the Government are $\$ 400,000$. The total estimated cost of the award is $\$ 425,000$. 
Modification - Mod Greater than "000"

\begin{tabular}{|l|c|c|c|c|}
\hline 26. Govemment Share & $\begin{array}{c}27 . \text { Awardee Share } \\
\text { 28. Total }\end{array}$ & $\begin{array}{c}\text { 29. B\&R No. } \\
-5000\end{array}$ & $\begin{array}{c}\text { 30. B\&R Dollars } \\
\text { A401 }\end{array}$ & 150,000 \\
\hline
\end{tabular}

The award was initially executed with $\$ 75,000$ awardee share. A modification is executed that decreases the awardee share-by $\$-5,000$ and incrementally funds the award for $\$ 150,000$.

\begin{tabular}{|c|c|c|c|c|}
\hline $\begin{array}{l}\text { 26. Goverrment Share } \\
100,000\end{array}$ & $\begin{array}{l}\text { 27. Awardee Share } \\
2,000\end{array}$ & $\begin{array}{l}\text { 28. Tatal } \\
102,000\end{array}$ & $\begin{array}{l}\text { 29. B\&R No. } \\
\text { AA01 }\end{array}$ & $\begin{array}{l}\text { 30. B\&R Dolars } \\
100,000\end{array}$ \\
\hline
\end{tabular}

The sward was initially executed for $\$ 400,000$ Government share, $\$ 25,000$ awardee share, and obligated dollars of $\$ 400,000$. A modification is executed that is an increase in scope of $\$ 100,000$ to the Government, $\$ 2,000$ to awardec, and obligations increased $\$ 100,000$.

ITEM 28 TOTAL; (Total Contract Value)

Enter the sum of Items 26 and 27 showing the total award amount. (Example: 150000)

Initial "000" Award

\begin{tabular}{|c|c|c|c|c|}
\hline $\begin{array}{l}\text { 26. Government Share } \\
105,000\end{array}$ & $\begin{array}{l}\text { 27. Awardee Share } \\
5,000\end{array}$ & $\begin{array}{l}\text { 28. Total } \\
105,000\end{array}$ & $\begin{array}{l}\text { 29. Q\&R No. } \\
\text { AA01 }\end{array}$ & $\begin{array}{l}\text { 30. B\&R Dolars } \\
50,000\end{array}$ \\
\hline
\end{tabular}

An action awarded for 3-year period for $\$ 100,000$ Government share, $\$ 5,000$ awardee share, and Government funds obligated is $\$ 50,000$. The total contract value is $\$ 105.000$.

\begin{tabular}{|c|c|c|c|c|}
\hline $\begin{array}{c}\text { 26. Government Share } \\
50,000\end{array}$ & $\begin{array}{c}27 \text {. Awardee Share } \\
10,000\end{array}$ & $\begin{array}{c}28 . \text { Total } \\
60,000\end{array}$ & $\begin{array}{c}\text { 29. B\&R No, } \\
\text { AA01 }\end{array}$ & $\begin{array}{c}\text { 30, B\&R Dollars } \\
50,000\end{array}$ \\
\hline
\end{tabular}

An action awarded for 3-year period for $\$ 50,000$ Government share, $\$ 10,000$ awardee share, and Government funds obligated is $\$ 50,000$. The total contract value is $\$ 60,000$.

Modification-Mod Greater than "Oog"

\begin{tabular}{|l|l|l|l|l|}
\hline 26. Government Share & 27. Awardee Share & 28. Total & $\begin{array}{c}\text { 29. B\&R No. } \\
\text { AA01 }\end{array}$ & $\begin{array}{c}\text { 30, B\&R Dollars } \\
50,000\end{array}$ \\
\hline
\end{tabular}


The award was initially executed for a total of $\$ 105,000$, and dollars obligated at the initial award were $\$ 50,000$. An incremental funding modification is awarded for $\$ 50,000$ and does not change award value.

\begin{tabular}{|c|c|c|c|c|}
\hline $\begin{array}{c}\text { 26. Govemment Share } \\
15,000\end{array}$ & 27. Awantee Share & $\begin{array}{c}28 . \text { Total } \\
15,000\end{array}$ & $\begin{array}{c}\text { 29. B\&R No. } \\
\text { AAOI }\end{array}$ & $\begin{array}{c}\text { 30. B\&R Dollars } \\
15,000\end{array}$ \\
\hline
\end{tabular}

The award was initially executed for a total value of $\$ 60,000$ and dollars obligated were $\$ 50,000$. An increase in scope modification is issued for $\$ 15.000$ and dollars obligated for the modification are $\$ 15,000$. This increases the contract value by $\$ 15,000$.

\section{ITEM 29 B\&R NUMBER}

Enter the valid B\&R (Budget and Reporting) number (maximum nine characters) (Item 26 on DOE F 4200.33) for the FY funds obligated by this award action, If there are more B\&R numbers than the three spaces provided, use the IPAR Supplement (DOE Form 4200.41). (Example: HA0502)

ITEM 30 B\&R DOLLARS

Enter the amount of obligated funds for each B\&R number in IPAR Item 29 for this award. (Example: 25000)

\section{ITEM 31 INTERNAL OFFICE USE ONLY}

This 30-character field is provided for individual awarding office use. It is an alpha numeric data field that may be used to store information unique to an individual award.

\section{GUIDANCE ON COMPETITION}

The competition data elements are required on a mod-by-mod-basis. The following guidance is provided to assist you in filling out the IPAR for modifications.

(1) Modifications within the scope of an existing contract shall carry the same competitive/noncompetitive designation as the original contract award. Therefore, date reported in Items $32,35,38,41$, and 44 for modifications within scope must be the same as the basic award.

If the modification being executed is for new work, i.e., outside the scope of the original contract, the modification should be reported as noncompetitive in ltems $32,35,38,41$ and 44 .

The competitive/noncompetitive coding of a modification issued subsequent to a new work modification (outside the original scope) should 
be judged on the basis of predominance of the work being modified, i.e. original scope of work or the new work; whichever is the predominant work being modified or changed.

EXAMPLE:

Original Award is Competitive

MODS

OBS

$\begin{array}{lllll}\text { A000 } & \text { Contract Value } & \$ 2,500,000 & \$ 500,000 & \text { COMP } \\ \text { A001 } & \text { Original Scope } & & \$ 200,000 & \text { COMP } \\ \text { A002 } & \text { Original Scope } & & \$ 300,000 & \text { COMP } \\ \text { A003 } & \text { Original Scope } & & \$ 400,000 & \text { COMP } \\ \text { A004 } & \text { Outside Original Scope } & \$ 50,000 & & \text { N/COMP } \\ \text { A005 } & \text { Original Scope } & \$ 100,000 & & \text { COMP } \\ \text { A006 } & \text { Original Scope } & \$ 300,000 & & \text { COMP } \\ \text { A007 } & \text { Outside Original Scope } & \$ 35,000 & & \text { N/COMP }\end{array}$

(2)

For orders against indefinite delivery contracts, GSA contracts, basic ordering agreements, and other agency contracts, data reported in liems $32,35,38,41$ and 44 should follow the same competitive designation as the original award or other agency contract. (GSA has stated that close to $100 \%$ of their Federal Supply Sctiedule awards are competitively awarded.)

\section{ITEM 32 CICAAPPLICABILITY}

Enter the appropriate 1-character code that indicates the CICA applicability.

\section{CODE DESCRIPTION}

1 Pre CICA

2 Post CICA

$3 \quad$ Simplified Acquisition Procedure

CODE DEFINITION

Pre CICA

Enter this code if the action resulted from a solicitation issued before April 1, 1985 irrespective of the award date. Modifications within the original scope of work of such awards are reported as PRE-ClCA.

In the case of a modification after April 1, 1985, for work outside the original scope of a PRE-CICA contract, CICA is applicable to such a modification. 
Enter this code if the new award or modification resulted from solicitations issued on or after April 1, 1985.

Simplified Acquisition Procedure

Enter this code if this action is a simplified acquisition pursuant to procedures in FAR Part 13. (Imprest funds are excluded)

\section{ITEM 33 TYPE OF BUSINESS}

Enter the 3-character code that identifies the type of business to which the award was made.

\section{CODE DESCRIPTION}

A11 Small Business 8(a)

A22 Small Business-Direct Disadvantaged

A33 Small Business - Other

B11 Large Business-Minority

B22 Large Business-Other

C1A Historically Black College/Univ, or Minority Institution (HBCUMI)

C1G State/Local Government-Educational

C1N Non-Profit Private Educational

C2G State/Local Government-Hospital

C2N Non-Profit Hospital

C3G Other State/Local Government

C3N Other Non-Profit institution

C4N JWOD Non-Profit Agency

C5G State/Local Government-Research

C5N Non-Profit-Research

E1N Foreign Contractor

E2N Domestic Contractor Performing Out of US

F1N Federal Prison Industries (FPI)

F2N Other Federal Government

CODE DEFINITION

A11 Small Business-8(a)

A small disadvantaged business receiving an award through the Small Business Administration 8(a) program.

A22 Small Business-Direct Disadvantaged

A small disadvantaged business receiving an award directly from DOE.

A33 Small Business - Other

A small business that is not disadvantaged. 
A large business that is at least 51 percent owned by one or more individuals of a minorify group.

B22 Large Business - Other

A large business that is not 51 percent owned by one or more individuals of a minority group.

C1A Historically Black College/University or Minority Institution(HBCW/MIl) An educational institution classified as an HBCU or MI. (See Appendix $F$ for listing of these instiftutions.)

C1G State/Local Government-Educational

A State or local govemment educational institution. This includes public schools at the elementary, secondary, and post secondary levels.

C1N Non-Profit-Private Educational

A nonprofit, private educational organization. This includes private schools at the elementary, secondary, and post-secondary levels.

C2G State/Local Govemment-Hospital

A State or local government hospital.

C2N Non-Profit-Hospital

A private, non-profit hospital.

C3G Other State/Local Government

Any other organization which is part of a state or local government, including research organizations which are part of a state or local government.

C3N Other Non-Profit Institution

A non-profit institution that is not øducational, not a hospital, not a nonprofit agency, or not a research organization and, thus, does not belong in the other non-profit codings. Examples of this type of institution are: boy clubs, bar associations, bird watcher societies.

C4N JWOD Non-Profit Agency

An organization functioning as a non-profit agency for blind or severely handicappod.

C5G Statel Local Government Research

A State or local govemment supported research organization.

C5N Non-Profil Research

A non-profit research institution, foundation, or laboratory. 
An award to a source outside the US and its outlying areas or if the award is to a foreign government (or any agency or instrumentality thereof.)

E2N Domestic Contractor Performing Out of US

An award to a source inside the US and its outlying areas, but where the principal place of performance will be outside the US and its outlying area.

F1N Federal Prison Industries (FPl)

Self explanatory

F2N Other Federal Government

Any Federal agency other than Federal Prison Industries.

ITEM 34 ADVISORY AND ASSISTANCE SERVICES

This data is no longer required. Leave blank.

IIEM 35 NUMBER OF OFFERS

Enter the code that represents the range for the actual number of offers/biots received in response to the solicitation.

\section{CODE NUMBER}

$\begin{array}{ll}\text { A } & 1 \\ \text { B } & 2-5 \\ \text { C } & 6-10 \\ \text { D } & 11-15 \\ \text { E } & 16-20 \\ \text { F } & 21-50 \\ \text { G } & \text { Over } 50\end{array}$

ITEM 36 SMALL, SMALL DISADVANTAGED, AND WOMEN OWNED BUSINESS SUBCONTRACTING PLAN

Check the block marked "Yes" if the contract has a subcontracting plan covering smeil, small disadvantaged, and woman owned business concerns (FAR 19.702(a)). Check the błock marked "No" if a small, small disadvantaged and woman owned business subcontracting ptan is not inciuded in the contract 


\section{ITEM 37 TYPE OF AWARD}

Enter the 1-character letter code applicable to the award.

\section{CODE DESCRIPTION}

$\begin{array}{ll}\text { A } & \text { Fixed Price Redetermination } \\ J & \text { Firm Fixed Price } \\ \text { K } & \text { Fixed Price Economic Price Adjustment } \\ \text { L } & \text { Fixed Price Incentive } \\ \text { M } & \text { Interagency/lnternational Agreement } \\ \text { O } & \text { Cost No Fee - Special Research Contract } \\ \text { P } & \text { No Flinds } \\ \text { R } & \text { Cost Plus Award Fee } \\ \text { S } & \text { Cost No Fee } \\ \text { T } & \text { Cost Sharing } \\ \text { U } & \text { Cost Plus Fixed Fee } \\ \text { V } & \text { Cost Plus Incentive Fee } \\ \text { Y } & \text { Time and Materials } \\ \text { Z } & \text { Labor Hours } \\ \text { CODE } & \text { DEFINITION }\end{array}$

A

Fixed Price Redetermination

Fixed Price Contract with prospective price redetermination provides for (a) a firm fixed price for an initial period of contract deliveries or performence and (b) prospective redetermination, at a stated time or times outuing performance, of the price for subsequent periods of performance. (FAR 16.205-1)

J Fim Fixed Price

Provides for a price that is not subject to any adjustment on the basis of the contractor's cost experience in performing the contract. (FAR 16.202-1)

K Fixed Price Economic Price Adjusiment

Provides for upward and downward revision of the stated contract price upon the occurrence of specified contingencies. (FAR 16.203-1)

L Fixed Price Incentive

Provides for adjusting profit and establisting the final contract price by a formula based on the relationship of final negotiated total cost to total target cost. (FAR 16.204) 
Interagency/lnternational Agreement

An award between DOE and other Federal agencies, a foreign government or international organization.

- Cost No Fee Special Research Contract

Special research contract with non-profit or educational institutions.

No Funds

An award not involving equipment or obligation of Federal funds, e.g., terms and conditions only.

$\mathbf{R}$

Cost Plus Award Fee

A cost-reimbursement contract that provides for a fee consisting of (a) a base amount (which may be zero) fixed at inception of the contract and (b) an award amount based upon a judgmental evaluation by the government, sufficient to provide motivation for excellence in contract performance. (FAR 16.305).

Cosi Nò Fee

Cost-reimbursement contract in which the contractor recelves no fee. (FAR 16.302(a).

Cost Sharing

Cost-reimbursement contract in which the contractor receives no fee and is reimbursed only for an agreed upon portion of its allowable costs. (FAR 16.303)

U Cost Plus Fixed Fee

A cost-reimbursement contract that provides for payment to the contractor of a negotiated fee that is fixed at the inception of the contract. (FAR 16.306)

V Cost Plus Incentive Fee

A cost-reimbursement contract that provides for an initially negotiated fee to be adjusted later by a.formula based on the relationship of total allowable costs to total target costs. (FAR 16.304)

Y Time and Materials

Provides for acquiring supplies or services on the basis of (1) direct labor hours at specified fixed hourly rates that include wages, overhead, general and administrative expenses, and profit and (2) materials at cost, including, if appropriate, material handling costs as part of material costs. (FAR 16.601) 
Labor Hours

A variation of the time-and-materials contract, differing only in that materials are not supplied by the contractor. (FAR 16.602)

\section{ITEM 38 COMPETITIVE SOLICITATION PROCEDURES}

Enter the 1-character code identifying the procedures used to promote and provide for full and open competition.

CODE DESCRIPTION

A Full and Open Competition - Sealed Bid

B Full and Open Competition - Competitive Proposal

C Full and Open Competition - Combination

D Architect-Engineer

E Basic Research

F Multiple Award Schedule

G Alternate Sources

K Set-Aside

L Other Than Full and Open Competition

\section{CODE DEFINITION}

Full and Open Competition - Sealed Bid

A competitive procedure to be used when time permits for solicitation, submission, and evaluation of sealed bids;and award is based on price and other price-reated factors; it is necessary to conduct discussions; and, there is a reasonable expectation of recoiving. (See FAR 6.102 (a))

B Full and Open Competition - Competitive Proposal

A competitive procedure which permits negotiation through the use of competitive proposals when sealed bidding is not appropriate (FAR Part $6.102)(b)$

C Full and Open Competition - Combination of Competitive Procedures Allows the Government the benefits of sealed bidding when adequate specifications are not available. This is referred to as two-step sealed bidding. (See FAR 6.102 (c)).

D Architect-Engineer

A competifive solicitation procedure that involves selection of sources for AVE contracts in accordance with P.L. 92-582, (40 U.S.C. 541 et seq.) (See FAR 6.102(d)(1)).

Selection of source for AVE confracts shall be in accordance with the AVE competitive procedure rather than sealed bidding or competitive proposals. 
A competitive solicitation procedure where award results from (i) a broad agency announcement that is general in nature identifying areas of research interest, and (ii) a peer or scientific review is required. (See FAR 6.102(d)(2))

$\mathbf{F}$

Multiple Award Schedule

A competitive solicitation procedure for an award of a multiple award schedule or an order against a multiple award schedule pursuant to FAR $6.102(d)(3)$.

When reporting orders against G\$A multiple award schedule contracts, Item 38 must be code $F$.

$\mathbf{G}$

Alternate Sources

A competitive solicitation procecture which provides for full and open competition atter exclusion of sources. (FAR 6.202(a)(1) through FAR $6.202(a)(6))$

K

Set-Aside

A competitive solicitation procedure where the solicitation is set aside for a preference program. (See FAR 6.203) Use this code for $B(a)$ awards that were competed pursuant to FAR 6.204. Use cade "L" when reporting sole source 8(a) awards pursuant to FAR $6.302 .5(b)(4)$.

L Other Than Full and Open Competition

Used when contracting without providing for nomal full and open competition. The authorities for use are set forth in FAR Subpart 6.3 and defined in ltem 41.

When Code $L$ is used, an entry is required in Item 41.

Use the appropriate extent competed in ltem 44 when Code $L$ is used.

NOTE: 8(a) contracts that are sole source should be coded $L$ in item 38 and coded $M$ in item 41. Competed $8(a)$ awards should be caded " $K$ ", set aside.

\section{ITEM 39 WOMAN OWNED BUSINESS}

Check the block marked "YES" if the contractor is certified as a woman-owned business as defined in FAR Subparts $52.204-5$ or $52.212-3$ (c)., Otherwise, check the block marked "NO". 


\section{ITEM 40 SAFETY AND HEALTH CLAUSE}

Check the block marked "Yes" if there is a safety and health clause in the contract award. Check the block marked "No" if a safety and health clatuse is not included in the contract award.

ITEM 41 COMPETITION EXEMPTION AUTHORITY

Enter the 1-character code identifying the circumstances providing for other than full and open competition in the procurement process (FAR 6.3). (Item 38 must equal $L$ when Item 41 is entered.)

CODE DESCRIPTION

A Unique Source

B Follow-on Contract

C Unsolicited Research Proposal

D Patent/Data Rights

E Utilities

F Standardization

G Only One Source-Other

H Urgency

J Mobilization, Essential R\&D, or Expert Services

L International Agreement

M Authorized by Stalute

N Authorized Resale

$P \quad$ National Securtity

Q Public Interest

\section{CODE DEFINITION}

Uinique Source

One source or supplier with unique capabilities. (See FAR 6.302-1(b)(1))

Follow-on Contrack

Continued development or production of a major system or highly specialized equipment available from the original source when award to any other source would result in (1) substantial duplication of cost to the Government, or (2) unacceptable delays in fulfilling the requirements. (See FAR 6.302-1(a)(2)(ii)) (Primarily used at Department of Defense). A new procurement (whether by seperate new contract or a modification outside the scope of the original contract) placed with a particular contractor to continue a specific program, where placement was necessitated by prior acquisition decisions. 
Acceptance of an unsolicited research proposal available from one source demonstrating a unique and innovative concept. (See FAR $6.302-1(a)(2)(i))$

D Patent/Data Rights

Existence of limited rights in data, patent rights, copyrights, or secret processes; control of basic raw material, or similar circumstances (See FAR 6.302-1(b)(2)) (See FAR Part 27 for further explanation).

$\mathbf{E}$

Utilities

Acquiring electric power or energy, gas (natutal or manufactured), water, or other utility services when only one supplier can furnish services or when the contemplated contract is for construction of a part of a utility system and the utility company itself is the only source available to work on the system. (FAR 6.302-1(b)(3))

F Standardization

Agency Head has determined only specific makes and models of technical equipment and parts will satisfy agency's needs for additional units or replacement items and only one source is availab!e. (See FAR $6.302-1(b)(4))$

$\mathbf{G}$

Only One Source-Other

Any reason not covered in codes $A$ through $F$ above for selection of only one source. (See FAR 6.302-1)

H U Urgency

An unusual and compelling urgency precludes full and open competition and delay in award would result in serious injury, to the Govemment unless the agency is permitted to limit the number of sources from which it solicits bids or proposals. (See FAR 6.302-2)

Mobilization. Essential R\&D or Expert Services Report this code if the action was justified pursuant to FAR 6.302-3(a)(2)

L Intemational Agreement

Used when the terms of an international agrement or a treaty between the U.S. and a foreign government/international organization, or the written direction of a foreign government reimbursing the agency for the cost of the acquisition of the supplies or services for such government, preclude full and apen competition. (See FAR 6.302-4) 
Authorized by Statute

Used when a statute expressly authorizes or requires that the acquisition be made through another agency or from a specified source. (FAR $6.302-5(a)(2)(i)$

NOTE: SBA 8(a) contract actions that are sole source should be coded M. (FAR 6.302.5(b)(4)\}

N Aulhorized Resale

Used only for purchases of brand-name commercial items for resale through commissaries or other similar facilities. (FAR 6.302-5(a)(2)(ii))

$P$

National Sacurtity

Used for any acquisition when disclosure of the agency's needs would compromise the national security unless the agency is permitted to limit the number of sources from which it solicits bids or proposals. (FAR $6.302-6)$

Q

Public interest

Used when the agency head determines that it is not in the public interest for the particular acquisition concemed. (FAR 6.302-7)

ITEM 42 PREFERENCE PROGRAM

Report the code that represents the preference program used in making the award, or enter " $G$ " if the award was not made under a preference program listed.

\section{CODE DESCRIPTION}

A Directed to JWOD Non-Profit Agency

B 8 (a) Contract Award

D Small Business Set-Aside

G No Preference Program or not listed

J Small Disadvantaged Business Set-Aside

CODE DEFINITION

A Directed to JWOD Non-Profit Agency

For a directed award to a non profit agency for the blind or severely handicapped pursuant to FAR 8.7.

B B(a) Contract Award

For actions with the Small Business Administration pursuant to FAR 19.8. 
D Small Business Set-Aside

For a smatl business set-aside award or for a partial small business set-aside award made pursuant to FAR 13.105, 19.502-2, or 19.502-3.

$\mathbf{G}$

No Preference Program or Not Listed

Report this code if the award is not made pursuant to a Preference program, or the preference program is not isted above.

Small Disadvanteged Business Set-Aside

For actions for a small disadvantaged business set-aside award made pursuant to FAR Part 19.

\section{ITEM 43 SUBJECT TO LABOR STATUTES}

Enter the appropriate code that indicates whether the award is subject to certain Labor Statutes.

\section{CODE $\quad$ DESCRIPTION}
A Walsh-Healey Act
C Service Contract Act
D Davis-Bacon Act
E Not subject to Walsh-Healey, Service Contract or Davis-Bacon Acts

If code " $D$ " is used, the Product and Service Code must begin with $Y$ or $Z$.

\section{ITEM 44 EXTENT COMPETED}

Enter the 1-character code indicating the level of competition for this action.

\section{CODE DESCRIPTION}
A
Competed Action
B Not Available For Competition
C Follow on To Competed Action
D Not Competed

\section{CODE DEFINITION}

\section{A Competed Action}

Competitive procedures were used to fulfill the requirement for full and open competition (See FAR 6.I).

Full and open competition was proviced for after exclusion of sources, in order to establish/maintain alternative sources or to set-aside a procurement for small business (See FAR 6.2). 
Full and open compefition was provided for after exclusion of sources to compete 8(a) awards with an anticipated award price (including options) of $\$ 5$ million for manufacturing or $\$ 3$ million for other acquisitions. (FAR 6.204)

Statutory authorities for other than full and open competition were used and more than one offer was received. (See FAR 6.3)

Contract action resulted from a contract awarded prior to CICA that used two step formal advertising or was negotiated competitively.

Simplified acquisition procedures were used and competition was obtained.

Not Available for Competition

Awards for utilities (excluding telecommunications) where there is no opportunity for competition.

Brand name commercial products for authorized resale.

Procurement authorized or required by statute to be awarded to a designated source.

Sole source \&(a) program awards pursuant to FAR 6.302.5(b)(4).

Other contract actions where DOE has deterrnined that there is no opportunity for compettition.

C Foliow-on to Competed Action

When an action pertains to an acquisition placed with a particular contractor to continue or augment a specific competed program where such placement was necessitated by prior acquisition decisions.

D Not Competed

Use this code when codes $A, B$, and C DO NOT APPLY.

ITEM 45 HISPANICINSTITUTION

Yes - An institution of higher learning where at least $25 \%$ of the student population is Hispanic.

No - Not an institution of higher learning where at least $25 \%$ of the student population Is Hispanic. 


\section{ITEM 46 PRQDUCT AND SERVICE_P\&S) CODE}

Enter the 4-character code to identify the correct type of product or service associated with this award. For listing of valid P\&S codes, see "Product and Service Codes," issued by Federal Procurement Data Center for the Office of Federal Procurement Policy (OFPP), Office of Management and Budget (OMB), or the PADS miscellaneous table PROD. (This code should be consistent with IPAR Item 58.)

\section{ITEM 47 EXTENT OF COMPETITION}

Enter the 2-character code which reflects the level of competition obtained for this PRE-CICA action.

\section{CODE DESCRIPTION}

$\begin{array}{ll}\text { AA } & \text { Two-step Formal Advertising } \\ \text { AC } & \text { Other Formal Advertising } \\ \text { BP } & \text { One Acceptable Offer Following Competition } \\ \text { BX } & \text { Other Negotiated Competitive } \\ \text { CE } & \text { Follow-on After Competition } \\ \text { CG } & \text { Unsolicited Proposal } \\ \text { Cl } & \text { Utilities } \\ \text { CQ } & \text { Other Negotiated Noncompetitive } \\ \text { DA } & \text { Directed Source (Federal PTtson Industries) } \\ \text { DC } & \text { Other Federal Government }\end{array}$

\section{CODE DEFINITION}

AA Two-step Formal Advertising

A method of procurement designed to promote the maximum competition practicable when available specifications are not sufficiently definite to permit a formally actvertised procurement. (41 CFR 1-2.5)

\section{AC Other Formal Advertising}

A rigid process of obtaining sealed bids, opening them in public, and then awarding a contract to the responsive, responsible bidder whose bid will be most advantageous to the Government, price and other factors considered. (41 CFR 1-2)

BP One Acceptable Offer Following Competition

Following competition, only one acceptable offer is received. 
BX Other Negotiated Competitive

Any negotiated competitive procurement not covered by another category. A negotiated procurement that (1) is initiated by a Request for Proposal, which sets out the Government's requirements and the criteria for evaluation of offers; (2) contemplates the submission of timely proposals by the maximum number of possible offerors; (3) usually provides discussion with those offerors found to be within the competitive range; and (4) conciudes with the award of a contract to the one considered most advantageous to the Government. (41 CFR 1-3)

CE Eollow-on After Competition

A follow-on contract is a new procurement (whether by separate new contract or a modification outside the scope of the original contract) placed with a particuler contractor to continus a specific program, where placement was necessitated by prior decisions, used if selection of the contracter at the beginning of the program was based on competition.

CG Unsolicited Proposal

A written offer to perform a proposed task or effort, initiated and submitted to the Government by a prospective contractor without a solicitation by the Government. (41 CFR 1-4,9)

Cl Wtilities

Procurement of public utility services, such as electricity, gas, steam, water and sewerage, inclucing facilities on both sides of the delivery point for supply of these services. (41 CFR 1-4.4)

CQ Qther Negotiated Nencompetitive

Any negotiated, noncompetitive procurement not covered by another category. Circumstances under which one source has exclusive capability to perform the work within the time required and at reasonable prices, e.g. by reason of experience, specialized facilities, or tectnical competence. A justification (Justification for Noncompetitive Procurement) is required for limiting competition to that source.

DA Directed Source (Federel Prison lndustries) Procurement with Federal Prison Industries.

DC Other Federal Government

Procurement with ahother Federal Agency 


\section{ITEM 4⿻ COMMERCIAL.ITEM}

Yes - Report "Yes" if the contract action is for a commercial item procured pursuant to the procedures in FAR Part 12 (Acquisition of Commercial ltems) and clause 52.212-4 was included in the contract.

No - Report "No" if the action is not for a commercial jtem procured pursuant to FAR 12.

\section{ITEM 49 SIC CODE}

Enter the 4-digit code from the OMB Standard Industrial Classification Manual. If more than one code applies, report the code that best identifies the product or service acquired and represents the predominance of the dollars for the contract action.

ITEM 50 SYNOPSIS REQUIREMENT

Enter the 1-character code identifying the synopsis requirement for the award.

\section{CODE DESCRIPTION}

1 Synopsized prior to award

2 Not synopsized due to urgency

$3 \quad$ Not synopsized for other reason

ITEM 51 SMALL BUSINESS COMPETITIVENESS DEMONSTRATION PROGRAM

Mark "Yes" for any contract action awarded to U.S. business concems as a result of a solicitation issued on or after January 1, 1989, under the Denonstration Program for the four designated industry groups or the 10 targeted industry categories. Mark "No" if the award is not in this program. If "no", items 54,57, and 60 are not entered.

\section{ITEM 52 DIRECTED PROCUREMENT}

Check the block marked "Yes" if a foreign government or international organization bearing any part of the cost of the action. (Primarily used at Department of Defense.) Otherwise mark "No".

\section{ITEM 53 TRADE DATA - COUNTRY OF MANUFACTURE}

If acquiring supplies or equipment manufactured, mined, or grown in a foreign country, enter the country code. If a service is performed by a foreign contractor enter the code for that country. See Appendix_D for Country Codes. 
Mark "Yes" for an award to a business concern whose size is na greater than 50 percent of the numerical size standard applicable to the standard industrial classification code assigned to the industries. (Size standards in FAR 19.) Mark "No" if the award is not emerging small business, Leave blank if item 51 is "No".

\section{ITEM 55 OSTI DELIVERABLE}

This data is utilized by the Office of Scientific and Technical Information (OSTI) and the Technicel Information Monitoring System (TIMS) to provide closeout data to DOE procurement offices. Enter the 2-character code that best describes the reporting schedule for technical deliverables as specified on DOE.F 1332.1, "Reporting Requirements Checklist or Form EIA 459A "Federal Assistance Reporting Checklist" or in the statement of work. The code should not be used to identify any other reporting requirements.

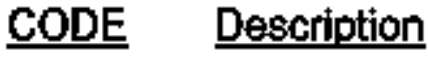

$\begin{array}{ll}\text { AA } & \text { Annual } \\ \text { AD } & \text { Final } \\ \text { AH } & \text { Quarterly Plus Annual } \\ \text { AK } & \text { Quarterly Plus Final } \\ \text { AL } & \text { Quarterly } \\ \text { AM } & \text { Semiannual } \\ \text { AN } & \text { Interim or Topical Plus Final } \\ \text { AU } & \text { Conference Proceedings } \\ \text { AZ } & \text { No Technical Deliverable Required } \\ \text { BD } & \text { Monthly Plus Final } \\ \text { BE } & \text { Monthly Plus Quarterly Plus Annual Plus Final } \\ \text { BG } & \text { Monthly } \\ \text { BI } & \text { Special (Books, Films, etc.) } \\ \text { BJ } & \text { Monthly Plus Annual } \\ \text { BM } & \text { Semiannual Plus Final } \\ \text { BO } & \text { Semiannual Plus Aninual Plus Final } \\ \text { BV } & \text { Annual Plus Final } \\ \text { BW } & \text { Quarterly Plus Semiannual Plus Annual } \\ \text { CD } & \text { One Interim or Topical } \\ \text { CF } & \text { Monthly Plus Quarterly Plus Final } \\ \text { CG } & \text { Bimonthly Plus Final } \\ \text { CH } & \text { Monthly Plus Annual Plus Final } \\ \text { CM } & \text { Two Interim or Topical } \\ \text { CN } & \text { Three Interim or Topical } \\ \text { CQ } & \text { Quarterly Plus Annual Plus Final } \\ \text { CT } & \text { Master Contract (No Reports Required) } \\ \text { CU } & \text { Technical Deliverables but no Technical Reports }\end{array}$


CW Terminated or Cancelled

DD Other

MO Requirement not specified (M\&O contractor, etc.)

YY Computer Software

YZ Computer Software Plus Final

\section{ITEM 56 COGNIZANT DQE OFFICE}

The contracting activity assigned lead office responsibility for all DOE indirect cost matters relating to a particular organization receiving DOE contract and financial assistance awards.

The responsible office is determined by predominance of DOE business with the specific contractor. This information is available from the contractor or through PADS Report 707, Instruments that Require Annual Indirect Rate Determination.

\section{ITEM 57 SIZF OF SMALL BUSINESS}

Enter the code that corresponds to the range of the number of employees or the range of the average annual gross revenue for the small business contractor recejving the award. Leave blank if ltem 51 is "No".

NUMBER OF EMPLOYEES Or

CODE DESCRIPTION

$\begin{array}{ll}\text { A } & 50 \text { or less } \\ \text { B } & 51-100 \\ \text { C } & 101-250 \\ \text { D } & 251-500 \\ \text { E } & 501-750 \\ \text { F } & 751-1,000 \\ \text { G } & \text { Ovar } 1,000\end{array}$

AVERAGEANNUALGROSSREVENUE

\section{CODE DESCRIPTION}

M $\$ 1,000,000$ or less

N $\$ \$ 1,000,001-\$ 2,000,000$

P $\$ 2,000,001-\$ 3,500,000$

R $\$ 3,500,001-\$ 5,000,000$

S $\$ 5,000,001-\$ 10,000,000$

T $\$ 10,000,001-\$ 17,000,000$

Z Over $\$ 17,000,000$

ITEM 58 RESEARCH AND DEVELOPMENT

Check the block marked "Yes" if 50 percent or more of the funding on this award is considered to be for research and development. Otherwise, check "No". This code should be consistent with the product and service code in Item 46. 


\section{IIEM 59 COGNIZANTFEDERAL AGENCY}

The agency having the predominate financial interest in the organization. The CFA is responsible for performing a designated function on behalf of all Federal agencies.

This information is available from the contractor or from PADS Report 707, Instruments that Require Annual Indirect Rate Determination.

CODE DESCRIPTION

$\begin{array}{ll}\text { DA } & \text { Department of Agriculture } \\ \text { DC } & \text { Department of Commerce } \\ \text { DD } & \text { Defense Contract Mgrnt Command } \\ \text { DE } & \text { Department of Education } \\ \text { DG } & \text { Department of Energy } \\ \text { DH } & \text { Department of Housing \& Urban Development } \\ \text { DJ } & \text { Department of Justice } \\ \text { DL } & \text { Department of Labor } \\ \text { DN } & \text { Office of Naval Research } \\ \text { DP } & \text { Environmental Protection Agency } \\ \text { DS } & \text { National Science Education } \\ \text { DT } & \text { Department of Transportation } \\ \text { DX } & \text { Other } \\ \text { R1 } & \text { HHS Northeast Office, New York } \\ \text { R2 } & \text { HHS Mid-Atlantic Office, Atlanta } \\ \text { R3 } & \text { HHS Central States Office, Dallas } \\ \text { R4 } & \text { HHS Eastern Office, San Francisco }\end{array}$

ITEM 60 EMERGING SMALL BUSINESS RESERVE AWARD

Mark "Yes" if the action resulted from an award that was reserved for a emerging small business concern. Mark "No" if not emerging small business. (See the Pub. L. 100,656, Business Opportunity Development Reform Act of 1988, Section 712(b)(2) for further definition.) Leave blank if item 51 is "No".

ITEM61 GOVERNMENT PROPERTY

Enter the 1-character code which property indicates if Government properiy is involved in the award. 


\section{CODE DESCRIPTION}

$\begin{array}{ll}\text { F } & \text { Fumished } \\ \text { N } & \text { None } \\ \text { P } & \text { Purchased } \\ \text { B } & \text { Both Furnished and Purchased } \\ \text { R } & \text { Removed }\end{array}$

\section{ITEM62 EPACT}

Yes - $\quad$ Action applies to the Energy Policy Act of 1992 (Pub. L. 102-486). (DEAR 917.70 and DOE Financial Assistance Rules 600.107 and 600.206)

No - EPACT does not apply.

\section{ITEM 63 SUPPORT SERVICE}

Check the block marked "Yes" if this procurement awerd is a support service award; check the block marked "No" if the action is not a support service.

Technical support services include, but are not limited to, determining feasibility of design consideration; development of specifications, system definition, system review and reliability analyses; trade-of analyses; economic and environmental analyses, which may be used in DOE's preparation of environmental impact statements; test and evaluation, survey or reviews to improve the effectiveness, efficiency, and economy of technical operations.

Management support services include, but are not limited to, analyses of workload and work flow, directives management studies; automated data processing; manpower systems analyses; assistance in the preparation of program plans; training and education; analyses of Department management processes; and any other reports or analyses directed toward improving the effectiveness, efficiency, and economy of management and general administrative operations.

Maintenance and operations services include, but are not limited to, general housekseping and custodial services, physical security, fire fighting, logistics, and maintenance.

EXCLUSION from coverage under these definitions are: Research and Development (R\&D) contracts unless the primary purpose of the work under a R\&D contract is for technical support services covered by the defintion in the first paragraph above. 
Also architectural and engineering services which are procured under the Brooks Act guidelines; construction and construction management services; management and operating contracts; and production contracts and services thereunder.

\section{ITEM 64 MULTI-YEAR AWARD}

Check the block marked "Yes" if procurement action is a multi-year award pursuant to the procedures in FAR Subpart 17.1. Check the block marked "No" if procurement is not a multi-year award.

"Multi-year contracts," means contracts covering more than 1-year but not in excess of 5-year's requirements, unless otherwise authorized by statute. Total contract quantities and annual quantities are planned for a particular level and type funding as displayed in a current 5-year development plan. Each program year is annually budgeted and funded, and, at the time of award, funds need only to have been appropriated for the first year. The contractor is protected against loss resulting from cancellation by contract provisions which allow reimbursement of costs included in the cancesllation ceiling. (FAR 17.101).

ITEM 65 EPACT VALUE

Enter amount of the funding action that will be used to further the goals of the Energy Policy Act. Funding may be equal to or less then the obligation amount funded.

\section{ITEM66 NEGOTIATOR CODE}

Enter the 4-character code which identifies the individual who completed the procurement action. This code is unique to each awarding office for their personnel.

ITEM 67 PATENT CLEARING OFFICE

Enter the 2-character code indicating the DOE office responsible for reviewing patent disclosures resulting under the award and for giving final patent office clearance before closeout of a completed award.

\section{CODE DESCRIPTION}
AL
Albuquerque Operations Office
CA Oakland Operations Office
$\mathrm{CH}$ Chicago Operations Office
$\mathrm{HQ}$
OR Heacquarters, Washington, DC
RI Oak Ridge Operations Office
SR
Rictiland Operations Office
Savannah River Operations Office 
Enter the 2-character code that identifies the technical representative office assigned the responsibility (by the Contracting Officer) to provide a Government Technical Representative (GTR). See Appendix G for codes.

ITEM 69 CONTRACTING OFFICER CODE

Enter the 4-character code which identifies the person duly authorized with contracting officer warrant, who signed the contractual document. This code is unique to each awarding office for their personnel.

\section{ITEM 70 DELEGATED AWARD ADMINISTRATION OFFICE}

If award audit and/or property administration is delegated, enter the proper 2-character code that identifies the delegated office. If the award is delegated outside $\mathrm{DOE}$, this value must be entered. If this item is entered, Item 73 must be completed.

\section{CODE DESCRIPTION}

01

02

03

04

05

06

07

08

09
Washington Procurement Operations Office Chicago Operations Office Oakland Operations Office Albuquerque Operations Office Oak Ridge Operations Office Richland Operations Office Idaho Operations Office Nevada Operations Office Savanneh River Operations Office Pittsburgh Naval Reactors Office Schenectady Naval Reactors Office Grand Junction Project Office Portsmouth Project Office Environmenta: Measurements Laboratory Bartlesville Project Office Morgantown Energy Technology Center Pittsburgh Energy Technology Center Fernald Area Office Ohio Field Office Los Alamos Area Office Kansas City Area Office Rocky Flats Office Golden Field Office Boston Support Office Philadelphia Support Office 


$\begin{array}{ll}44 & \text { Atlanta Support Office } \\ 45 & \text { Chicago Support Office } \\ 48 & \text { Denver Support Office } \\ 51 & \text { Richland Support Office } \\ 65 & \text { Western Area Power Administration } \\ 70 & \text { Southeastern Power Administration } \\ 75 & \text { Southwestern Power Administration } \\ 85 & \text { Alaska Power Administration } \\ 91 & \text { Naval Petroleum and Oil Shale Reserves } \\ 92 & \text { California Naval Petroleum } \\ 96 & \text { Strategic Petroleum Reserve Office } \\ \text { DA } & \text { DCMC (Defense Contract Management Command) } \\ \text { DC } & \text { DCAA (Defense Contract Audit Agency) } \\ \text { MO } & \text { Management and Operating Contractor } \\ \text { ON } & \text { ONR (Office of Naval Research) } \\ \text { OT } & \text { Other }\end{array}$

ITEM 71 TECHNICAL REPRESENTATIVE NAME

Enter the name of the person delegated the responsibility to serve as the Government Technical Representative (GTR) by the Contracting Officer (up to 24 characters). Enter last name, first name, middle initial.

ITEM 72 AWARD ADMINISTRATOR CODE

Enter the 4-character code which identifies the person who is responsible for administration of the contract. This code is unique to each awarding office for their personnel.

\section{ITEM 73 DELEGATIONDATE}

Enter the date (MMDD/MMY) on which the award administration was delegated. This date must be entered if Iterm 70 is completed.

\section{IIEM 74 IECHNICAL REPRESENTATNE TELEPHONE NUMBER}

Enter the telephone number where the DOE technical representative can be contacted. (Example: 202-586-5000) 
Enter the 2-character code which reflects the appropriate status of the contract. These codes are optional for field use. They will not be used by Headquarters to generate reports and thus are not used to determine status of award.

\section{CODE DESCRIPTION}

AA Active, contract in performance from award date to completion date.

AX Payback-Awardee Liability open.

CA Completion date passed, no final acceptance of deliverables, still open.

CO Completed with finat acceptance of deliverables; closeout action initiated.

RA Closeout completed. Retirementaging begun.

RC Converted to Subcontract.

RD Retired, file destroyed.

ITEM 76 RETIIREMENTICONVERTED DATE

Enter the date (MMOOMM the completed award was retired, i,e., all deliverables have been received and final payment made; or enter the date a DOE prime contractor was converted to a subcontractor under a prime contract.

ITEM 77 PROJECTMANAGER NAME

Enter the name of the DOE project manager assigned responsibility for the controlling and reporting on this project. Enter last name, first name, middle initial. (24 characters allowed)

\section{ITEM 78 TRANSFER AWARDING OFFICE}

This item is to be blank, unless a contract is to be trensferred from one DOE awarding office to another. At the time of a transfer, the transferring office enters the office number $(01,02$, etc.) of the awarding office receiving the transferred award. 
ITEM 79 SSENIOR INVESTIGATOR

Name of person designated by the awardee to seve as Project Director or Senior Investigator.

ITEM 80 CONTRACTING OFFICER SIGNATURE

The duly authorized official who signed the contract. 


\section{INSTRUCTIONS FOR IPAR SSUPPLEMENT FORM}

The IPAR supplement, DOE F 4200.41, is used when there are more than three B\&R codes and three dollar amounts for the award, and additional space is needed to complete the obligation information for the award, when more than one mod is definitized and additional space is needed, or when an awarding office finds it recessary to enter data in the fields 8 through 11 for collecting information unique to that office. (Further definitions of items below are found in DOE F 4200.40 defiritions.)

\section{IIEM 1 ADD/CHANGE}

Check "Add" if this is a new basic award or a modification (to an existing award) not previously reported to PADS. Check the block marked "Change" if this award action is a change to award/modification data previously enter into PADS.

\section{ITEM 2 AWARD BIN}

This number is the 17-character identifying number to the legal document which constitutes the agreement between the Department of Energy and the awardee. (See instructions for ltern 2, Award Bin, of IPAR - DOE 4200.40.)

ITEM 3 AWARD DATE

Enter the date (MMODMM $)$ that the contracting officer signed the award.

ITEM 4 MOD NUMBER

Enter the 4-character modtfication number that identifies the award document.

ITEM 5 B\&R NUMBER

Enter the valid $B \& R$ (Budget and Reporting number) (maximum nine characters) for the FY funds obligated by this award action. (Example: HA0205)

ITEM6 DOLLARS

Enter the amount of FY obligated dollars on this action for each B\&R number (ltem 5).

ITEM7 MOD NUMBER BFING DEFINITIZFED

Enter the modification number ( $\mathrm{A}-\mathrm{-}$ or $\mathrm{M}-\mathrm{-}$ ) ) being deflnitized that was previously awarded as a unilateral change order, letter modification, or letter contract. (Continued from Item 5 on DOE 4200,40) 


\section{ITEM 8 DATE}

Enter any date (MMODOMY).

ITEM 9 DOLLARS

Enter any dollar value (15 characters).

ITEM 10 TEXI

Enter any alpha/numeric information (120 characters).

ITEM 11 NUMERIC

Enter any numeric information (30 characters). 


\section{ITEM 1 ADD/CHANGE}

Check "ADD" if this is a new basic award or a modification (to an existing award) not previously reported to PADS. Check the block marked "CHANGE" if this award action is a change to an award/modification previously reported to PADS.

ITEM 2 AWARD BIN (BUSINESS INSTRUMENT NUMBER)

Enter the identifying number to the legal document which constitutes that agreement between the Department of Energy and the awardee.

Referencing DOE Order 1331.2B, "Depertmental Business Instrument Numbering System," dated 05-18-92:

Award Business Instrument Number. The award business instrument number consists of 17 characters and has the following format DE-AC01-05FE12345. The encoded information in the number is as follows:

(1) The first and second positions, DE-AC01-951FE12345, contain the wo-character code assigned by the Federal Procurement Data Center to identify Department of Energy awards.

(2) The third position contains a dash.

(3) The fourth and fifth positions, DE-AC01-95FE12345, contain a two-character code corresponding to the type of award instrument. (The type of Award Instrument Codes and definitions follow on pages 54 and 55 )

(4) The sixth and seventh positions, DE-AC01-95FE12345, identify the responsible awarding office (The Awarding Office codes follow the page 53 )

(5) The eighth position is a dash.

(6) The ninth and tenth positions, DE-AC01-95FE12345, will contain the last two digits of the fiscal year of the award date of the basic award:

(7) The eleventh and twelfth positions, DE-AC01-95FE12345, contain a two-character code showing the initiating office ( For Initiating Office Codes see Appendix G). Due to Departmental reorganizations, some award business instrument numbers contain codes that are no longer used for new awards.

(8) The thirteenth through seventeenth positions, DE-AC01-95FE12345, will contain a five-digit serial number assigned by the initiating office.

The last seven digits of the award BIN is referred to as the Register Number.

This number remains unchanged from initiation through retirement. 
01 Washington Procurement Operations Office

02 Chicago Operations Office

03 Oakland Operations Office

04 Albuquerque Operations Office

05 Oak Ridge Operations Office

06 Richland Operations Office

07 Idaho Operations Office

08 Nevada Operations Office

09 Savannah River Operations Office

11 Pittsburgh Naval Reactors Office

12 Schenectady Naval Reactors Office

13 Grand Junction Project Office

16 Portsmouth Project Office

17 Environmental Measurements Laboratory

19 Bartlesville Project Office

21 Morgantown Energy Technology Center

22 Pittsburgh Energy Technology Center

23 Femald Field Office

24 Ohio Field Office

32 Los Alamos Area Office

33 Kansas City Area Office

34 Rocky Flats Office

36 Golden Field Office

41 Boston Support Office

43 Philadelphia Support Office

44 Atlanta Support Office

45 Chicago Support Office

48 Denver Support Office

51 Richland Support Office

65 Westem Area Power Administration

70 Southeastern Power Administration

75 Southwestern Power Administration

85 Alaska Power Administration

91 Naval Petroleum and Oil Shale Reserves

92 Califomia Naval Petroleum

96 Strategic Petroleum Reserve Office 
FC

FG

FL

FM

FP

FR

CODE

FC

FG

FL

FM

FP
Cooperative Agreement

Grant

Loan of Mories

Loan Guarantee

Loan of Property

Repayment Agreement

DEFINITION

\section{Cooperative Agreement}

A legal instrument reflecting a relationship between the Federai Government and a State or local government or other recipient whenever - (1) the principal purpose of the relationship is the transfer of money, property, services or anything of value to the State or local government or other recipient to accomplish a public purpose of support or stimulation authorized by Federal statute, rather than acquisition, by purchase, lease, or barter, or property or services for the direct benefit or use of the Federal Government; and (2) substantial involvement is anticipated between the executive agency, acting for the Federal Government, and the State or local government or other recipient during performance of the contemplated activity.

\section{Grant}

A legal instrument reflecting a relationship between the Federal Government and a State or local government or other recipient whenever - (1) the principal purpose of the relationship is the transfer of money, property services, or anything of value to the State or local government or other recipient in order to accomplish a public purpose of support or stimulation authorized by Federal Statute, rather than acquisition, by purchase, lease, or batter, or property or services for the direct benefit or use of Federal Government; and (2) no substantial involvement is anticipated between the executive agency, acting for the Federal Government, and the State or local government or other recipient during the performance of the contemplated activity.

\section{Lean of Monies}

A financial assistance type of instrument for the lending of Federal monies for a specific period of time with a reasonable expectation of repayment.

\section{LMarn Guarantes}

Loan guarante $\theta$ is a financial assistance type instrument whereby the Government agrees to guarantes portions of a loan, revolving credit fund or other financial arrangernent under which the gutaranteeing agency is obligated, on demand of the lender, to purchase a stated percentage of the loan and to share any losses in the amount of the guarantee percentage.

\section{Logn of Property}

The lending of Federal property for a specified period of time, with a reasonable expectation that it will be retumed. 
Repayment to the Government of the Government's contribution after completion of the award, and the awardee is making a profit from the research. Applies only to the Clean Coal Cooperative Agreements under CFDA 81.096.

\section{ITEM3 MODIFICATION NUMBER}

Award Modification Numbers. All new basic awards and modifications to an award are identified by a modification number assigned by the awarding office. These modiffcation numbers are not part to the award business instrument number.

(1) The basic award and modifications to each business instrument shall be sequentially numbered by use of a four position alphanumeric code.

(a) The first position shall be a capitat letter identifying the type of action as follows:

A - (Amount). An action adding, changing, or deleting financial date that is collected on the IPAR, but not adrinistrative corrections to financial data.

M - (Miscellaneous). An action having no effect on financial data that is coilected on the IPAR, including administrative corrections.

(b) The second through fourth positions shall contain a sequential serial number of the modification. For basic awards, enter 000 . The next assigned modification number would be 001,002 , etc. These numbers continue in sequence throughout the life of the award.

(2) Examples of modifications:

(a) M001 - first modification to basic award, no effect on financial data in this example since it is a miscollaneous mod.

(b) A0ب02 - second modification to basic award, changes in financial data in this example since it is an amount mod.

(c) M003 - third modification to basic award, no effect or financial data in this example since it is also a miscellaneous mod.

NOTE: The mods are nurnbered sequentially without regard to the "A" or " $\mathrm{M}$ " grefix.

\section{IIEM4 KIND OF AWARD ACTION}

Enter the 2 character code which identities the appropriate action taken. 
iA New Definitive Award

CODE DESCRIPTION-Modifications

if Termination by Mutual Agreement

1H Continuation Award

$1 \mathrm{M}$ Termination for Default

Supplemental Agreement - Monetary Action

1Q Renewal Award

iT

Incremental Funding (Only)

No Cost Time Extension (Only)

Administrative Change

TR

Funding Adjustment to Completed Award

Other

Transferred Award

CODE DEFINITION

\section{NEW AWARDS}

New Definitive Award

The establishment of a binding legal relationship between the Government and awardee, contractor, or grante日 for the purpose of receiving supplies, services, construction, research and development, or providing financial assistence.

\section{MODIFICATION}

IF Termination by Mutual Agreement

DOE may terminate grants/cooperative agreements in whole, or in part, when both parties agree that the continuation of the project would not produce beneficial results commensurate with the further expenditure of funds.

Continuation Award

A financial assistance award authorizing a second or subsequent budget period within an existing project period.

Termination for Defattl

The exercise of the Government's contractual right to completely or partially terminate a contract because the contractor's or awardee's actual or anticipated failure to perform its contractual obligations.

The supplemental agreement is an amendment increasing the obligations including increase in funds for current budget period. 
A financial assistance award authorizing the first budget period of an extended project period.

Incremental Funding (Oniv)

The obligation of funds to an award containing a tatal price, estimated cost, or estimated value, in periodic instaltments against prescribed performance goals or objectives. (The modification is notmally unilateral with an increase in obligations only.)

No Cost Time Extension (Only)

A modfication which extends only the period of performance under an award with no increase in the total face value or obligated dollars.

Administrative Change

A unilateral modification to an award instrument which changes administrative data; e.g., paying office, technical representative, etc.

1X Funding Adjustment to Completed Award

A modification issued to an award instrument which has been completed wherein funds need to be obligated or deobfigated before it can be retired.

Other

"Catch all" code used to report modirication actions which did not meet the criteria of the other codes. This code includes revision award actions not otherwise covered by other codes such as terms and conditions of award, increase in funds because of an increase in performance effort, etc.

TR Transferred Award

A financial assistance award that is being transferred from one awarding office to another. The office transferring the award is responsible for transfer modifications.

\section{IIEM 5 PROCUREMENT REQUEST NUMBER}

A. Enter the 16-character number of the PR that authorized this award (e.g., $01-95 F E 12345.000$ ) from block 3 of the DOE Form 4200.33. (Only one PR number allowed in Item 3).

B. The basic portion of a procurement request number is twelve characters long in a format exempified by 01-95FE12345. This is identical to the last 12 characters of the award business instrument number, with the following exception: for a procurement request number, the fiscal year portion reflects the fiscal year of the anticipated award date. For example, the basic portion of a procurement request number which initiated a procurement action for a new award in FY 1995 would be in the form of 
01-95FE12345. Subsequent actions in FY 1995 would have the same basic portion for their procurement request numbers. For actions related to this award in FY 1996 , the procurement request number would be in the form of 01-96FE12345.

With regard to the eward business instrument number, however the fiscal year portion of this number remains the same as the year in which the instrument was initially awarded, this example, FY 1995. Therefore, regardless of the fiscal year of the procurement request, the fiscal year portion of the award business instrument number does not change.

The supplementary portion of the procurement request number consists of a decimal point followed by a three-digit number added to the right of the basic portion of the procurement request number. The number identifies the sequence of procurement requests initiated for a fiscal year. The number is assigned sequentially starting with " $000^{\text {" }}$ and is used to represent funding actions or any other action that involves procurement activity, e.g., a no-cost extension.

To continue with the previous example, the procurement request number that initiated the basic award would be $01-95 F E 12345.000$. The next action in FY 1995 would be a modification with a procurement request number 01-95FE12345.001. This supplemental portion does not become pert of the award business instrument. Each fiscal yeer a new sequence begins with "001". The " $000^{\prime \prime}$ is used only once during the life of the award.

Sometimes the awarding office will initiate a modification action under an award where the initiating office need not issue a procurement request. To provide for this case, the three-character sequence has been divided to have the awarding office use " 501 " through " 599 ". If, in the above example, the awarding office were to initiate its own first procurement request under the award in FY 1995 to change the cognizant contracting officer, it would be coded as 01-95FE12345.501.

The use of a different series prevents duplication of procurement request numbers that might occur when two separate offices are issuing procurement requests.

The following examples further explain the supplementary portion of the procurement request number:

01-95FE12345.000 - New award initiation.

01-95FE $\{2345.001$ - First subsequent action in FY 1995.

01-95FE12345.002 - Second subsequent action in FY 1995.

01-96FE12345.001 - First subsequent action in FY 1996.

01-96FE12345.002 - Second subsequent action in FY 1996

01-96FE12345.501 - First awarding office action in FY 1996. 
c. There are three types of financial assistance processing which do not require a procurement request number in order to process an award. They are AN-NOPR, SH-NOPR and PRFY-NOPR.

\section{(1) AN-NOPR Processing}

It is the procedure in some awarding offices to award zero dollar mods to an award without entering any procurement request forms. This process may be used for current year actions only. The following step is necessary to process AN-NOPR transactions.

Fill out an IPAR form with a Mod Number (Item 3) beginning with " $M$ " and

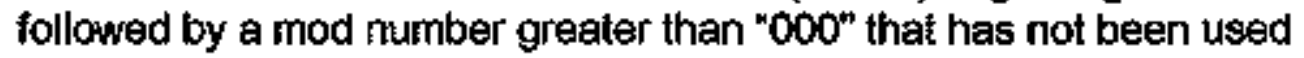
previously for that award. No financial information is allowed on this action. The PR Number (Item 5) must contain AN-NOPR to identify this type of action.

(2) SH-NOPRProcessing

SH-NOPR processing is used to report grants and grant modifications on schools and hospitals awards (CFDA 81.052) that do not have procurement requests.

Fill out an IPAR as follows: The PR number, ltem 5, must contain SHNOPR.

(3) PRFY-NOPR Processing

PRFY-NOPR processing is used to report awards from previous fiscal years. This special process is allowed so actions that have not been entere due to oversight do not requite the entry of a PR.

Enter PRFY-NOPR in Item 5 on the IPAR. This may be used for dollar or no dollar new awards and modifications from previous fiscal years.

\section{ITEM 6 PR COMPLETION CODE}

Check the block indicating whether the PR referenced in Item 5 is completed or still open for further action.

\section{CODE DESCRIPTION}

YES The PR is completed by this action.

No The PR is not completed by this action and will be used again.

PR completion code is required on all actions, including NO-PR actions. 


\section{ITEM 7 VENDORID}

Enter the 13-character Vendor ID code for the recipient and division. The Vendor ID codes can be found in the Directory of Awardee Names, DOE/OSTI, issued by the Office of Scientific and Technical Information (OSTI) in Oak Ridge, Tennessee. The Vendor ID in the Directory must match the name, division (ff applicable), city, and state of the awardee.

If no Vendor ID code is listed in the Directory, for the exact name, diviston (if applicable) city and state of the awardee, the awardee name (Item 8) must be entered, and division (Itern 9) if applicable, in accordance with the Instructions for Completing Awardee Names in PADS, Appendix E to this handbook.

\section{ITEM 8 AWARDEE NAME}

Enter the recipient name (up to 30 characters) of the individual, partnership, corporation, firm, assoctation, Federal, State, or local agency or other type of recipient of the new award. Formatting abbreviations are to be in accordance with Instructions for Completing Awardee Names in PADS, Appendix E. (System-generated Item 7 is entered.)

\section{TTEM 9 DIVISION}

When applicable, enter the name of the functional suborganization of the recipient in Item 8 above, Awardee Name. (See Appendix E, Instructions for Completing Awardee Names in PADS for further instructions.) (Example: Cable Division) (System generated if Item 7 is entered.)

\section{ITEM 10 CITY}

Enter the name of the city that is the principal place of performance of the award (up to 30 characters). (Example: Dallas).

\section{ITEM 11 STATE}

Enter the 2-character U.S. Postal Service Code for the state or U.S. outlying area (includes Puerto Rico, U.S. territories, and Freely Associated States) that is the principal place of performance of the award. See Appendix $\mathrm{C}$ for codes.

\section{IIEM 12 ZIP CODE}

Enter the 9-digit zip code which applies to the location of recipient (legal addiress). (Example: 22134-9700)

Zip Codes are listed in the U.S. Postal Service National Zip Cade Directory.

For locations outside the U.S., leave zip code blank. 


\section{ITEM13 COUNTY}

Enter the name of the county that is the location of the principal place of performance of the award. (Example: Montgomery) For the District of Columbia (DC), and locations outside the U.S., leave county blank.

If city, state, and zip code are entered county will be system generated. If city within a state is in multiple counties, or if multiple cities with the same name are in a state, county must be entered.

\section{ITEM14 CONGRESSIONAL.DISTRICT}

Enter the 2-character code for the congressional district where the recipient is tocated (tegal address). These codes are listed in the Congressional District Atlas. (Example: 01)

ITEM 15 COUNTRY

Enter the 2-character code for the country that is the principal place of performance of the award. For locations in the U.S. and U.S. outlying areas leave this element blank.

A listing of country names and codes is found in Appendix D.

\section{ITEM 16 DESCRIPTION OF WORK}

Enter the brief description from the statement of work or project description (not less than 15 characters). A maximum of $\mathbf{1 5 0}$ characters (including spaces, dashes, etc.) may be entered. Insure the description is a concise statement of what is acquired or what work is being performed. Avoid use of abbreviations, acronyms and jargon if possible.

\section{IIEM 17 AWARD DATE}

Enter the date the DOE contracting officer signed the official award or modification (date executed). (Format: (MMIDDMMY)

ITEM 18 AWARD EFFECTIVE DATE (Begin Period of Performance)

Enter the date the award becomes effective. This date reflects the beginning of the period of performance. The effective date can be found in black 7 of DOE Notice of Financial Assistance Award, DOE F 4600.1 (Format: MMDDMYY) 
ITEM 19 AWARD COMPLETION DATE (End Period of Performance)

Enter the completion date of the award. This field must be filled out on the basic award and for all time extensions to the basic award. This date can be found in block 7 of DOE Notice of Financial Assistance Award, DOE F 4600.1. (Format: MMDDMYY)

\section{ITEM 20 BUDGET PERIOD FROM}

Beginning date of current budget period. Date can be found in block 6 of DOE Notice of Financial Assistance Award, DOE F 4600.1. (Format: MMDDM MYY).

ITEM 21 BUDGET PERIOD TO

Ending date of current budget period. Date can be found in block 6 of DOE Notice of Financial Assistance Award, DOE F 4600.1. (Format: MWDDMMY).

\section{O FINANCIAL DATA}

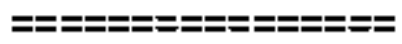

GUIDANCE:

a. Doflars are entered as whole dollars, no cents, no decimals, no comma .

b. Decreases in dollars should be preceded by "-". (Example; -2500).

c. Corrections to the previously entered financial data on modifications will replace current dollar values. There are three ways of making changes to the existing data:

1. Government share, awardee share and total (ltems 22, 23, and 24). A change to any one of these fields requires re-entry of data in all three. To leave dollars as they are on the data base, the same values must be re-entered.

If B\&R numbers and B\&R dollars (Items 25 and 26 ) are not entered, they will be left as they currently exist on the data base.

2. B\&R numbers andior B\&R dollars (ltems 25 and 26 ). A change made to any B\&R number or $B \& R$ dollar amount requites re-entry of all $B \& R$ numbers and their corresponding B\&R dollars.

If government share, awardee share, and total (Items 22, 23 and 24) are not entered, they will remain as they currently exist on the data base.

3. All five fields - government share, awardee share, total, B\&R number, and B\&R doilars (Items 22, 23, 24, 25 and 26). 


\section{ITEM 22 GOVERNMENT SHARE (DOE Face Value)}

For the basic award, enter the total dollar amount of DOE's share of the award amount. For a modification, enter the amount of increase or decrease to the current valuse. PADS will calculate the resultant value.

\section{Initial "0oo" Award}

\begin{tabular}{|c|c|c|c|c|}
\hline $\begin{array}{c}\text { 22. Government Share } \\
500,000\end{array}$ & 23. Awardee Share & $\begin{array}{c}\text { 24. Total } \\
500,000\end{array}$ & $\begin{array}{c}\text { 25. 8\&R No. } \\
\text { AA01 }\end{array}$ & $\begin{array}{c}\text { 26. E\&R Dollars } \\
200,000\end{array}$ \\
\hline
\end{tabular}

Assistance action awarded for a 3-year period for a total estimated cost to the Government of $\$ 500,000$. Funds-obligated at the time of initial award $\$ 200,000$. There is no awardee share.

\begin{tabular}{|c|c|c|c|c|}
\hline $\begin{array}{c}\text { 22. Govemment Stare } \\
300,000\end{array}$ & 23. Awardee Share & $\begin{array}{c}\text { 24. Total } \\
300,000\end{array}$ & $\begin{array}{c}\text { 25. 8\&R No. } \\
\text { AA01 }\end{array}$ & $\begin{array}{c}\text { 26. B\&R Dollars } \\
300,000\end{array}$ \\
\hline
\end{tabular}

Assistance action awarded for a 3-year period for a total estimated cost to the Government of $\$ 300,000$. Funds obligated at the time of initial award is $\$ 300,000$. There is no awardee share.

Modification - Mod Greater than "W0O"

\begin{tabular}{|l|c|c|c|c|}
\hline 22. Govemment Share & 23. Awardee Shere & 24. Total & $\begin{array}{c}\text { 25. B\&R No. } \\
\text { A401 }\end{array}$ & $\begin{array}{c}\text { 26. B\&R Dollars } \\
100,000\end{array}$ \\
\hline
\end{tabular}

Assistance action was initially executed for $\$ 500,000$; obligated dollars $\$ 200,000$. (See previous example) An incremental funding modification is awarded for $\$ 100,000$. This action has no effect on the Government share of the award; therefore, Item 22 is left blank.

\begin{tabular}{|c|c|c|c|c|}
\hline $\begin{array}{c}\text { 22. Govemment Share } \\
50,000\end{array}$ & 23. Awardee Share & $\begin{array}{c}\text { 24. Total } \\
50,000\end{array}$ & $\begin{array}{c}\text { 25. B\&R No. } \\
\text { AA01 }\end{array}$ & $\begin{array}{c}\text { 26. B\&k Dollars } \\
50,000\end{array}$ \\
\hline
\end{tabular}

Assistance action was initially executed for $\$ 300,000$; obligated dollars were $\$ 300,000$. An increase in scope modification is awarded for $\$ 50,000$, and dollars obligated for the mod is $\$ 50,000$. Item 22 is filled in with $\$ 50,000$ because of an increase of the Government share. 
For the basic award, enter the total doller amount of the awardeg's share of the award amount, if none, leave blank. For a modification, enter the amount of increase or decrease to the current awardee share value. PADS will calculate the resultant vatue.

Initial "000" Award

\begin{tabular}{|c|c|c|c|c|}
\hline $\begin{array}{c}\text { 23. Government Share } \\
250,000\end{array}$ & $\begin{array}{c}\text { 23. Awardee Share } \\
24 . \text { Total }\end{array}$ & $\begin{array}{c}\text { 25. B\&R No. } \\
\cdot\end{array}$ & $\begin{array}{c}\text { 26. B\&R Dodlars } \\
\text { AA01 }\end{array}$ & 325,000 \\
\hline
\end{tabular}

An action awarded for a 3-year period for a total estimated cost to the Government of $\$ 250,000$, a total estimated cost to the awardee of $\$ 75,000$, and the Government funds obligated at time of award are $\$ 250,000$. The total estimated cost of the award is $\$ 325,000$.

\begin{tabular}{|c|c|c|c|c|}
\hline $\begin{array}{c}\text { 22. Government share } \\
400,000\end{array}$ & $\begin{array}{c}\text { 23. Awerdee share } \\
25,000\end{array}$ & 24. Total & 25. B\&R Mo. & 26. B\&R Dollars \\
& 225,000 & AA01 & 400,000 \\
\hline
\end{tabular}

An action awarded for a 3-year period for a total estimated cost to the Government of $\$ 400,000$ a total estimated cost to the awardee of $\$ 25,000$, and the funds obligated of the Government are $\$ 400,000$. The total estimated cost of the award is $\$ 425,000$.

\section{Modification - Mod Greater than " 000 "}

\begin{tabular}{|l|c|c|c|c|}
\hline 22. Government Share & 23. Awardee Share & 24. Total & 25. B\&R No. & 26. B\&R Dolars \\
& $-5,000$ & $-5,000$ & AA01 & 150,000 \\
\hline
\end{tabular}

The award was initially executed with $\$ 75,000$ awardee share. A modification is executed that decreases the awardee share by $\$-5,000$ and incrementally funds the award for $\$ 150,000$.

\begin{tabular}{|c|c|c|c|c|}
\hline $\begin{array}{c}\text { 22. Government Share } \\
100,000\end{array}$ & $\begin{array}{c}\text { 23. Awardee Share } \\
2,000\end{array}$ & $\begin{array}{c}\text { 24. Total } \\
102,000\end{array}$ & $\begin{array}{c}\text { 25. B\&R No. } \\
\text { AA01 }\end{array}$ & $\begin{array}{c}\text { 26. B\&R Dellars } \\
100,000\end{array}$ \\
\hline
\end{tabular}

The award was initially executed for $\$ 400,000$ Government share, $\$ 25.000$ awardee share, and obligated dollars of $\$ 400,000$. A modification is executed that is an increase in scope of $\$ 100,000$ to the Government, $\$ 2,000$ to awardee, and obligations increased $\$ 100,000$. 
Enter the sum of Items 22 and 23 showing the total award amount

The total contract value is the "Total Estimated Cost of the Project," from block 17 of the DOE Notice of Financial Assistance Award, DOE F 460D.1, (Example: 150000)

Initial "000" Award

\begin{tabular}{|c|c|c|c|c|}
\hline $\begin{array}{c}\text { 22. Government Share } \\
100,000\end{array}$ & 23. Awardee Share & 24. Total & 25. B\&R No. & 26, B\&\& Dollars \\
& 5,000 & 105,000 & AA01 & 50,000 \\
\hline
\end{tabular}

An action awarded for 3-year period for $\$ 100,000$ Government share, $\$ 5.000$ awardee share, and Government funds obligated is $\$ 50,000$. The total contract value is $\$ 105,000$.

\begin{tabular}{|c|c|c|c|c|}
\hline $\begin{array}{c}\text { 22. Government Share } \\
50,000\end{array}$ & $\begin{array}{c}23 . \text { Awardee Share } \\
24 . \text { Total } \\
60,000\end{array}$ & $\begin{array}{c}\text { 25. B\&R No. } \\
60,000\end{array}$ & $\begin{array}{c}\text { 26. B\&R Dollars } \\
\text { AA01 }\end{array}$ & 50,000 \\
\hline
\end{tabular}

An action awarded for 3-year period for $\$ 50.000$ Government share, $\$ 10.000$ awardee share, and Government funds obligated is $\$ 50,000$. The total contract value is $\$ 60,000$.

Modification - Mod Greater than "OOO"

\begin{tabular}{|l|l|l|c|c|}
\hline 22. Government Share & 23. Awardee Share & 24. Total & $\begin{array}{c}\text { 25. B\&R No. } \\
\text { AA01 }\end{array}$ & $\begin{array}{c}\text { 26. B\&R Dallars } \\
50,000\end{array}$ \\
\hline
\end{tabular}

The award was initially executed for a total of $\$ 105,000$, and dollars obligated at the initial award were $\$ 50,000$. An incremental funding modification is awarded for $\$ \underline{\$ 0,000}$ and does not change award value.

\begin{tabular}{|c|c|c|c|c|}
\hline $\begin{array}{c}\text { 22. Govermment Share } \\
15,000\end{array}$ & 23. Awardee Share & 24. Total & 25. B\&R No. & 26. B\&R Dollars \\
& & 15,000 & AAO1 & 15,000 \\
\hline
\end{tabular}

The award was initially executed for a total value of $\$ 60,000$ and dollars obligated were $\$ 50,000$. An increase in scope modification is issued for $\$ 15,000$ and dollars obligated for the modification are $\$ 15,000$. This increases the confract value by $\$ 15,000$. 


\section{TEM 25 B\&R NUMBER}

Enter the valid B\&R (Budget and Reporting) number (maximum nine characters) (Item 26 on DOE F 4200.33) for the FY funds obligated by this award action. If there are more B\&R numbers than the three spaces provided, use the IPAR Supplement (DOE Form 4200.41). (Example: HA0502)

\section{ITEM26 B\&R DQLLARS}

Enter the amount of abiligated funds for each B\&R number for this award. (Example: 25000)

\section{ITEM 27 INTERNAL OFFICE USE ONEY}

This 30-character field is provided for individual awarding office use. It is an alphanumeric data field that may be used to store information unique to an individual award.

\section{ITEM 28 CATALOG OF FEDERAL DOMESTIC ASSISTANCE (CFDA) NUMBER}

Enter the 6-character Catalog of Federal Domestic Assistance (CFDA) number essigned to the program supporting the award. (Item 20 from DOE F 4200.33) This number should be selected by the sources of funds and not by matching the closest description. The CFDA number can be used only with funds originating from the appropriate program office.

CODE DESCRIPTION

81.003

81.004

81.022

81.036

81.039

81.041

81.042

81.048

81.049

81.052

81.057

81.064

81.065

81.077

81.079

81.080

81.081

Persons
Granting of Patent Licenses

University-Laboratory Cooperative Program

Energy-Related Laboratory Equipment Grants

Energy-Related Inventions

National Energy Information Center

State Energy Conservation

Weatherization Assistance for Low-income

Priorities \& Allocations for Energy Programs

Basic Energy Sciences, High Energy, etc.

Energy Conservation for Institutional Bulldings

University Coal Research

Office of Scientific \& Technical Information

Nuclear Waste Disposal Siting

Energy Research Instiumentation Program

Biomass Energy Technology

Energy Policy, Planning and Program Evaluation

Energy Task Force for the Urban Consortium
PROGRAM

$\mathrm{GC}$

ER

ER

EE

EE

EE

HR

ER

EE

FE

HR

RW

ER

EE

PE

EE 


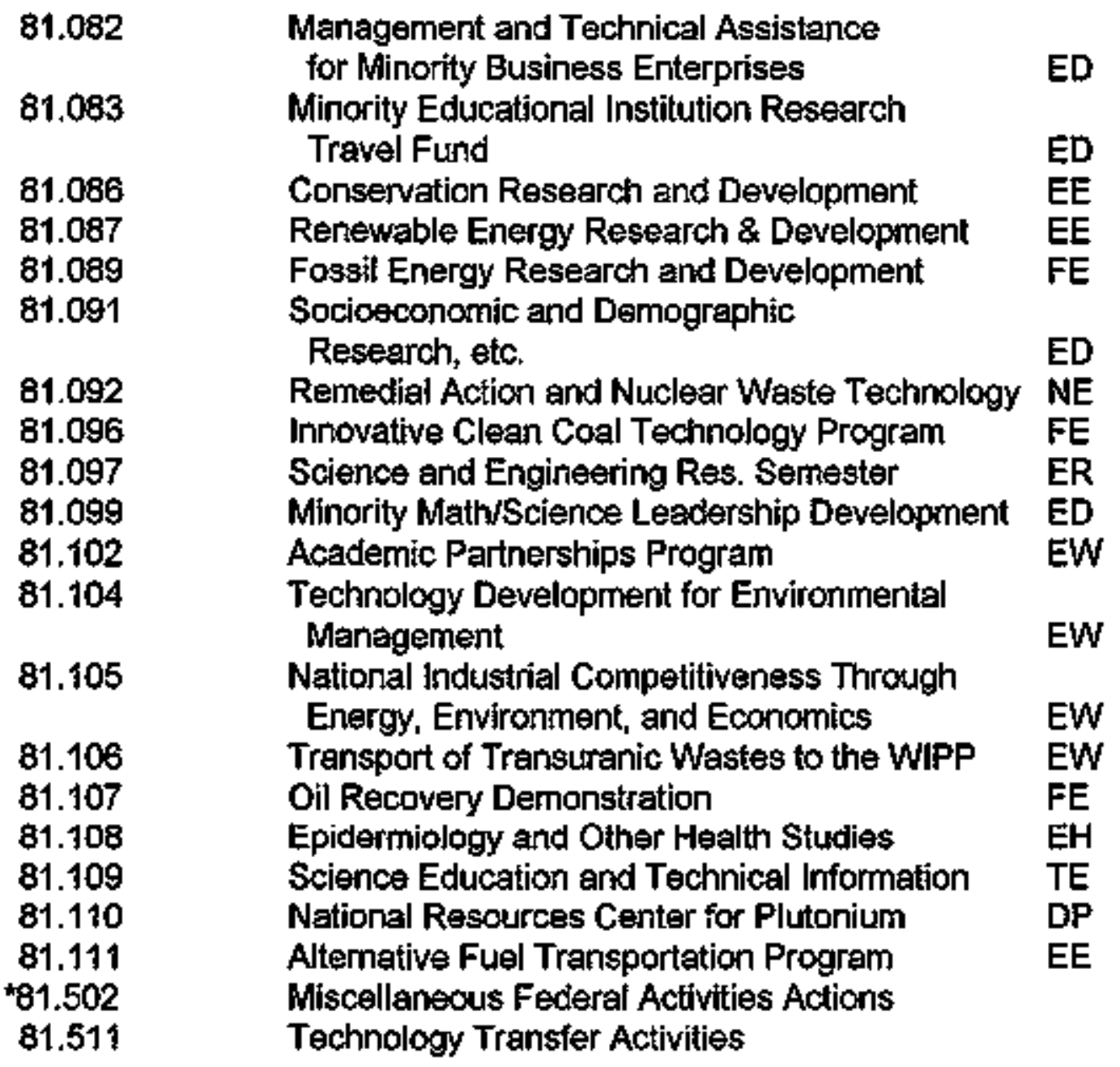

"This code can only be used after consultation with the Office of Clearance at Headquarters.

Other CFDA numbers are available for old programs that have modifications to their awards only.

ITEM 29 RACEJETHNIC CATEGORY OF BORROWER

Required for new assistance award when type of award is loan of monies (FL), loan guarantee (FM), or loan of property (FP).
B Black
1 Indian
N Nan-Designated
O Other Minority
S Spanish Speaking 
Enter the number assigned by the State's single point of contact (SPOC). SAI numbers are reported for all awards under programs that the agency has determined are covered by Executive Order 12372. The Office of Management and Budget (OMB) has established a standard 12-character format for SAl numbers. States have the option of adopting the standard format on a voluntary basis.

If the CFDA number is equal to any of the following, a State Application Identifier nurrber should be reported if it is available.

81.041

81.042

81.052

\section{LEGAL ADDRESS OF RECIPIENT}

Required on all new assistance awards.

SPECIAL INSTRUCTION: When legal address is the same as the principal place of performance address, the word "SAME" can be entered in the element CITY and the remainder left blank. PADS will generate this information for you.

\section{ITEM31 CITY}

Enter the specific name of the city or township where the recipient is located (same as billing address or legai address).

IIEM 32 STATE

Enter the 2-character code of the state or territory (includes Freely Associated States) where the recipient is located (legal address). See Appendix C for codes.

\section{ITEM 33 ZIP CODE}

Enter the 9-character zip code which applies to location of recipient (legal address). (Example: 22134-9700)

Zip Codes are listed in the U.S. Postal Service National Zip Code Directory. 


\section{ITEM 34 COUNTY}

Enter the county were the recipient is located. (Legal address) (Example: Montgomery) For the District of Columbia, leave county blank.

If city, state, and zip code are entered, county will be system generated. If city within a state is in multiple counties, or if multiple cities with the same name are in a state, county must be entered.

The FIPS 55 (Federal Information Processing Standard) provides information conceming city, county, and state.

\section{ITEM 35 CONGRESSIONAL DISTRICT}

Enter the 2-character code for the congressional district where the recipient is located (legal address). These codes are listed in the Congressional District Atlas. (Example: 01)

\section{ITEM 36 TYPE OF AWARD}

Enter the 1-character letter code applicable to the award.

\section{CODE DESCRIPTION}

B Cooperative Agreement

C Formula Grant

D Project Grant

E Direct Payment for Specifed Use

G Direct Loan

H Guaranteed/Insured Loan

3 Other Financial

CODE DEFINITION

B Cooperative Agreement

Assistance instrument with substantial involvement between DOE and recipient.

Formula Grant

Eligible recipients are determined by statute and amount is determined in accordance with a formula specified in stalute or implementing program rules. (ICP grants are considered formula grants for this purpose.) 
D

Project Grant

$\overline{D O E}$ is authorized under a Federal statute to select the recipient and the project to be supported and to determine the amount to be awarded.

E

Direct Payment for Specified Use

A financial assistance type award to encourage or subsidize a particutar activity.

G

DirectLoan

Lending of Federal funds with expectation of repayment.

H Guaranteedilnsured Loan

Indemnifies a lender against part or all of any default of repayment of a loan.

Other Financial Assistance

Financial assistance other than mentioned above.

\section{ITEM 37 EXTENT OF COMPETITION}

Required on all new assistance awards.

CODE DESCRIPTION

FC Competitive Assistance

FG Assistance Unsolicited Proposal

FN Noncompetitive Assistance

CODE DEFINITION

FC Competitive Assistance

Assistance awarded after competition.

FG Assistance Unsolicited Proposal

An application which is not submitted in response to a solicitation or which is submitted in response to a Notice of Program Interest. (10 CFR 600.15)

FN Noncompetitive Assistance

Assistance awarded without competition. 
This data is utilized by the Office of Scientific and Technical Information (OSTi) and the Technical Information Systern (TIMS) to provide closeout data to DOE awarding offices. Enter the 2-character code that describes the reporting schedule for technical deliverables as specified on EIA-459A, "Federal Assistance Reporting Checklist" or in the statement of work. The code should not be used to identify financial reporting requirements.

\section{CODE DESCRIPTION}

$\begin{array}{ll}\text { AA } & \text { Annual (Die on Contract Anniversary) } \\ \text { AD } & \text { Final } \\ \text { AH } & \text { Quarterly Plus Annual } \\ \text { AK } & \text { Quarterly Plus Final } \\ \text { AL } & \text { Quarterly } \\ \text { AM } & \text { Semiannual } \\ \text { AN } & \text { Interim or Topical Plus Final } \\ \text { AU } & \text { Conference Proceedings } \\ \text { AZ } & \text { No Tectnical Deliverable Required } \\ \text { BD } & \text { Monthly Plus Final } \\ \text { BE } & \text { Monthly Plus Quarterly Plus Annual Plus Final } \\ \text { BG } & \text { Monthly } \\ \text { BI } & \text { Special (Books, Films, etc.) } \\ \text { BJ } & \text { Monthly Plus Annual } \\ \text { BN } & \text { Semiannual Plus Final } \\ \text { BO } & \text { Semiannual Plus Annual Plus Final } \\ \text { BV } & \text { Annual Plus Final } \\ \text { BW } & \text { Quarterly Plus Semiannual Plus Annual } \\ \text { CD } & \text { One Interim or Topical } \\ \text { CF } & \text { Monthly Plus Quarterly Plus Final } \\ \text { CG } & \text { Bimonthly Plus Final } \\ \text { CH } & \text { Monthly Plus Annual Plus Final } \\ \text { CM } & \text { Two Interim or Topical } \\ \text { CN } & \text { Three Interim or Topical } \\ \text { CQ } & \text { Quarterly Plus Annual Plus Final } \\ \text { CT } & \text { Master Contract (No Reports Required) } \\ \text { CU } & \text { Technical Deliverables but no Technical Reports } \\ \text { CW } & \text { Terminated or Cancelled } \\ \text { DD } & \text { Other } \\ \text { MO } & \text { Requirements not specified (M\&O Contractor, etc) } \\ \text { VY } & \text { Computer Software } \\ \text { YZ } & \text { Computer Software Plus Final } \\ & \\ \end{array}$


Enter the 3-character code that identifies the type of recipient to which the award was made.

\section{TYPE OF RECIPIENT - ASSISTANCE ONLY}

$\begin{array}{ll}\text { GAA } & \text { State Government } \\ \text { GAE } & \text { State Higher Education Institution } \\ \text { GAH } & \text { State Hospital } \\ \text { GDD } & \text { County Government } \\ \text { GDE } & \text { County Higher Education Institution } \\ \text { GDH } & \text { County Hospital } \\ \text { GED } & \text { City or Township Higher Education Institution } \\ \text { GEE } & \text { City or Township Government } \\ \text { GEH } & \text { City or Township Hospital } \\ \text { GFF } & \text { Independent School District } \\ \text { GGG } & \text { Special District Government } \\ \text { GHH } & \text { Private Hospital-For Profit } \\ \text { GII } & \text { Private Higher Education Institution } \\ \text { GJJ } & \text { Indian Tribs } \\ \text { GKH } & \text { Other Hospital } \\ \text { GKK } & \text { All Others } \\ \text { GLL } & \text { Profit Organization } \\ \text { GMM } & \text { Individual } \\ \text { GNH } & \text { Non-Profit Hospital } \\ \text { GNN } & \text { NonProfit Organization } \\ \text { GSS } & \text { Small Business } \\ \text { GZZ } & \text { Recipient Outside US and Outlying Areas }\end{array}$

\section{TYPE OF RECIPIENT - ASSISTANCE ONLY}

GAA STATE GOVERNMENT

Includes all 50 States, the District of Columbia, and the outlying areas.

Includes State agencies, such as a State dormitory authority.

Includes the Governor's Office, the legislature and associated commiftees.

Daes not include institutions of higher education or hospital.

GAE STATE HIGHER EDUCATION INSTITUTION

Higher education institutions affiliated with a State, the District of Columbia, or a US outlying area. 
GAH STATE.HOSPITAL

Hospitals affiliated with a State, the District of Columbia or a US outlying area.

GDD COUNTY GOVERNMENT

Includes Governments designated as counties, boroughs in Alaska, parishes in Louisiana.

Includes subordinate agencies of the county government.

Includes school districts in states where they are designated as part of the county government.

Excludes consolidated cityfoounty governments, which are classified as cities.

GDE COUNTY HIGHER EDUCATION INSTITUTION

Higher education institutions afiliated with a county, borough in Alaska, or a parish in Louisiana.

GDH COUNTY HOSPITAL

Hospitals affiliated with a county, a borough in Alaska, or a parish in Louisiane.

GED CITY OR TOWNSHIP HIGHER EDUCATION INSTITUTION

Higher education institution affiliated with a city, town, township, borough in Pennsylvania, or a municipal corporation.

GEE CITYOR TOWNSHIP GOVERNMENT includes cities, towns, townships, boroughs in Pennsylvania, or a municipal corporation generally.

Includes subordinate agencies of the cities or towns.

Includes school districts in cities designated as having dependent school systems.

GEH CITY OR TOWNSHIP HOSPITAL Hospitals affiliated with a city, town, township, borough in Pennsylvania, or a municipal corporation.

GFF INDEPENDENT SCHOOLDISTRICT Includes only those districts designated as separate and independent units of government. 
GGG SPECIALDISTRICT GOVERNMENT

Includes governments so-designated under Bureau of Census guidelines, most of which are single-purpose governments.

Includes certain utility districts, housing authorities, park authorities, sewer authorities, industrial development authorities, and so forth.

GHH PRIVATE HOSPITAL - FOR PROFIT

Hospitals that are private and for profit.

GII PRIVATE HIGHER EDUCATION INSTITUTION

Includes institutions that are not state, city, or county operated colleges or universities.

\section{G.J INDIAN TRIBE}

Self explanatory.

GKH OTHER HOSPITAL

Hospitals that cannot be otherwise categorized.

GKK ALLOTHERS

Not otherwise classified. (Used for recipients which do not fit in any other category.)

GLL PROFIT ORGANIZATION

Includes profit organizations, except small businesses or otherwise categorized.

GMM INDIVIDUAL

Includes Social Secturity and VA beneficiaries and other non-business and non-Government recipients of federal assistance.

GNH NON-PROFIT HOSPITAL Hospitals that are non-profit and not affiliated with a State, county, or city.

GNN NON-PROFIT ORGANIZATION

Includes community action agencies and organizations having 501,c.3 status with the IRS, other than higher education institutions. Inciudes non-profit educational institution which are elementary, middle, jurior high or high schools.

GSS SMALL. BUSINESS

Private firms which are classified as small businesses with their particular indestry.

GZZ RECIPIENT OUTSIDE US AND OUTLYING AREAS

A recipient with a legal address outside the US and in outlying areas. 
ITEM 40 RESEARCH AND DEVELOPMENT

Check the block marked "Yes" if 50 percent or more of the funding on this award is considered to be for research and development. Check "No" if funding is less than 50 percent research and development.

\section{ITEM 41 GOVERNMENT PROPERTY}

Enter the 1-character code which properly indicates if Government property is involved in the award.

CODE DESCRIPTION

$\begin{array}{ll}\text { F } & \text { Furnished } \\ \text { N } & \text { None } \\ \text { P } & \text { Purchesed } \\ \text { B } & \text { Both Furnished and Purchased } \\ \text { R } & \text { Removed }\end{array}$

ITEM 42 HISPANIC INSTITUTION

Check "Yes" if awardee is an institution of higher learning where at least $25 \%$ of the student population is Hispanic. If not, check " $\mathrm{No}^{\prime \prime}$

ITEM 43 SMALL BUSINESS INNOVATNE RESEARCH (SBIR)

Check this block "Yes" if the award was made pursuant to the Small Business Innovation Development Act of 1982, P.L. 97-219. If not applicable, check "No".

ITEM 44 SMALL, BUSINESS TECHNOLOGY TRANSFER PROGRAM

Check this block "Yes" if the award was made pursuant to Title Il of the Small Business Research \& Development Enhancement Act of 1992, PL 102-564. If not applicable check " $\mathrm{No}$ ".

\section{ITEM 45 COGNIZANT DOEAGENCY}

The contracting activity assigned lead office responsibility for all DOE indirect cost matters relating to a particular organization receiving DOE contract and financial assistance awards.

The responsible office is determined by predominance of DOE business with the specific contractor. This information is available from the contractor or through PADS Report 707, Instruments that Require Annual Indirect Rate Determination. 
The agency having the predominate financial interest in the organization. The CFA is responsible for performing a designated function on behalf of all Federal agencies.

This information is available from the contractor or from PADS Report 707, Instruments that Require Annual Indirect Rate Determination.

CODE DESCRIPTION

DA Department of Agriculture

DC Department of Commerce

DD Defense Contract Mgmt Command

DE Department of Education

DG Department of Energy

DH Department of Housing \& Urban Development

DJ Department of Justice

DL Department of Labor

DN Office of Naval Research

DP Environmental Protection Agency

DS National Science Foundation

DT Department of Transportation

DX Other

R1 HHS Northeast Office, New York

R2 HHS Mid-Atlantic Office, Atlanta

R3 HHS Central States Office, Dallas

R4 HHS Eastern Office, San Francisco

\section{ITEM 47 NEGOTIATOR CODE}

Enter the 4-character code which identifies the individual who completed the assistance action. This code is unique to each awarding office for their personnel.

ITEM 48 CONTRACTING OFFICER CODE

Enter the 4-character code which identifies the person duly authorized with contracting officer warrant, who signed the contractual cocument. This code is unique to each awarding office for their personnel.

ITEM 49 AWARD ADMINISTRATOR CODE

Enter the 4-character code which identifies the person who is responsible for administration of the award. This code is unique to each awarding office for their personnel. 


\section{IIEM 50 AWARD STATUS}

Enter the 2-character code which reflects the appropriate status of the award.

These codes are optional for field use. They will not be used by Headquarters to generate reports and thus are not used to determine status of awerd.

CODE DESCRIPTION

AA Active, contract in performance from award date to completion date.

AX Payback-Awardee Liability open.

CA Completion date passed, no final acceptance of deliverables, still open.

Co Completed with final acceptance of deliverables, closeout action initiated.

RA Closeout completed. Retirement/aging begun.

RC Converted to Subcontract.

RD Retired, file destroyed.

\section{ITEM 51 PATENT CLEARING OFFICE}

Enter the 2-character code indicating the DOE office responsible for review of patent disclosures resulting under the award and for giving final patent office clearance before closeout of a completed award.

\section{CODE DEFINITION}

$\begin{array}{ll}\text { AL } & \text { Albuquerque Operations Ofice } \\ \text { SF } & \text { Oakland Operations Office } \\ \text { CH } & \text { Chicago Operations Office } \\ \text { HQ } & \text { Washington Procirement Operations Office } \\ \text { LA } & \text { Los Alamos Area Office } \\ \text { OR } & \text { Oak Ridge Operations Office } \\ \text { RI } & \text { Richland Operations Office } \\ \text { SR } & \text { Savannah River Operations Office }\end{array}$

ITEM 52 DELEGATED AWARD ADMINISTRATION OFFICE

If award and/or property administration is delegated, enter the proper 2-character code that identifies the delegated office. If the award is delegated outside DOE, this value must be entered. If this item is entered, Item 53 must be completed. 


\section{CODE DESCRIPTION}

01

02

03

04

05

00

07

08

0

11

12

13

16

17

19

21

22

23

24

32

33

34

41

43

44

45

48

51

65

70

75

85

96

DA

DC

MO

ON

OT
Washington Procurement Operations Office

Chicago Operations Office

Oakland Operations Office

Albuquerque Operations Office

Oak Ridge Operations Office

Richland Operations Office

Idaho Operations Office

Nevada Operations Office

Savannah River Operations Office

Pittsburgh Naval Reactor Office

Schenectady Naval Reactor Office

Grand Junction Project Office

Portsmouth Project Office

Environmental Measurements Laboratory

Bartlesville Project Office

Morgantown Energy Technology Center

Pittsburgh Energy Technology Center

Fernald Area Office

Ohio Field Office

Los Alamos Area Office

Kansas City Area Office

Rocky Flats Office

Boston Support Office

Philadelphia Support Office

Atlanta Support Office

Chicago Support Office

Denver Support Office

Richland Support Office

Western Area Power Administration

Southeastern Power Administration

Southwestem Power Administration

Aleske Power Administration

Strategic Petroleum Reserve Office

DCMC (Defense Contract Management Command)

DCAA (Defense Contract Audit Agency)

Management and Operating Contractor

ONR (Office of Naval Research)

Other

\section{ITEM 53 DELEGATION DATE}

Enter the date (MMDDMYM) on which the award administration was delegated.

This date must be entered if Item $\mathbf{5 2}$ is entered. 
ITEM 54 RETIREMENT DATE

Enter the date (MMDDMYY) the completed award was retired, i.e., all deliverables have been received and final payment made.

LIEM 55 TECHNICAL REPRESENTATIVE OFFICE

Enter the 2-character code that identifies the technical representative office assigned the responsibility (by the Contracking Officer) to provide a Government Technical Representative (GTR). Codes are listed in Appendix G.

\section{ITEM 56 TECHNICAL REPRESENTATIVE NAME}

Enter the name of the person delegated the responsibility to serve as the Government Technical Representative (GTR) by the contracting officer (up to 24 characters.) Enter last name, first name, middle initial.

\section{ITEM 57 TECHNICAL REPRESENTATIVE TELEPHONE NUMBER}

Enter the telephone number where the DOE technical representative can be contacted. (Example 202-586-5000)

\section{IIEM58 PROJECT MANAGERRAME}

Enter the name of the DOE project manager assigned responsibility for controlling and reporting on this project. Enter last name, first neme, middle initial. (24 characters allowed)

\section{IEM 59 TRANSFER AWARDING OFFICE}

This item is to be blank, unless a grant is to be transferred from one DOE awarding office to another. At the time of a transfer, the transferring office enters the awarding office number $(01,02$, etc.) of the awarding office receiving the transferred award.

ITEMGO SENIOR INVESTIIGATOR

Name of person designated by the awardee to serve as Project Director or Senior Investigator.

\section{ITEMG1 CONTRACTING OFFICER SIGNATURE}

The duly authorized official who signed the Notice of Financial Assistance Award. 


\section{INSTRUCTIONS FORIPAR SUPPLEMENT FORM}

The IPAR supplement, DOE F 4200.41, is used when there are more than three B\&R codes and three dollar amounts for the award, and additional space is needed to complete the obligation information for the award or to enter field office specific data. (Further definitions of items below are found in DOE F $4200.40 \mathrm{~A}$ definitions.)

\section{ITEM 1 ADD/CHANGE}

Check "ADD" if this is a new basic award or a moditication (to an existing award) not previously reported to PADS. Check the block marked "CHANGE" if this award action is a change or correction to award/modification data previously reported to PADS.

ITEM 2 AWARD BIN

This number is the 17.character identifying element to the legal document which constitutes the agreement between the Department of Energy and the awardee. (See instructions for ltem 2, Award Bin, of IPAR - DOE F4200.40A.)

ITEM 3 AWARD DATE

Enter the date contracting officer signed the official award. (Format: MMOD/MYM)

ITEM4 MODNUMBER

Enter the 4-character modification number that identifies the award document.

ITEM5 B\&RUMBER

Enter the valid B\&R (Budget and Reporting) number (maximum nine characters) for the FY funds obligated by this award action. (Example: HA0205)

ITEM6 DOLLARS

Enter the amount of FY obligated dollars on this action for each B\&R number (Item 5).

ITEM 7 MOD NUMBER BEING DEFINITIZED

Not applicable to financial assistance awards. 
ITEM 8 DATE

Enter any date (MMDDMMY).

ITEMO DOLLARS

Enter any dollar value (10 characters).

ITEM 10 TEXT

Enter any alpha'numeric information (120 characters).

IIEM11 NUMERIC

Enter any numeric information (30 characters). 
REQUIRED ITEMS - QUICK REFERENCE

REQUIRED ITEMS FOR PRE-CICA PROCUREMENT MODIFICATION WITH DOLLARS (A MOdS)

IPAR ITEM

1

2

3

4

6

7

22

26

27

28

29

30

32

44

47

50
IDENTIFICATION

Add/Change

Award Bin

Modification Number

Kind of Award Action

PR Nusnber

PR Completion

Award Date

Government Share (If

applicable)

Awardee Share (if applicable)

Total (If applicable)

B\&R Number (If applicable)

B\&R Do:lars (If applicable)

CICA Applicability

Extent Competed

Extent of Competition

Synopsis Requirement

REQUIRED ITEMS FOR PRE-CICA PROCUREMENT MODIFICATION NO DOLLARS (MODS)

\section{IPAR ITEM}

1

2

3

4

6

22

32

44

47
IDENTIFICATION

Add/Change

Award Bin

Modification Number

Kind of Award Action

PR Number

Award Date

CICA Applicability

Extent Competed

Extent of Competition 


\section{REQUIRED ITEMS FOR POST CICA NEW BASIC \\ PROCUREMENT AWARD (A \& M Mods)}

IPAR ITEM

1

2

3

4

6

7

8

9

10

11

12

13

14

15

16

17

18

19

20

21

22

23

24

25

26

27

28

29

30

32

33

34

35

36

37

38
IDENTIFICATION

Add/Change

Award Bin

Modification Number

Kind of Award Action

PR Number

PR Completion

Master BIN (If applicable)

DUNS Number

Vendor ID

Contractor Name (If no Vendor ID)

Division (If no Vendor ID and/or if applicable)

Contractor's TIN

Common Parent's Name (If applicable)

Common Parent's TIN (If applicable)

City

State

Zip Code

County (If city in multiple

counties)

Congressional District

Country (If applicable)

Award Date

Award Effective Date

Award Completion Date

Description of Work

Government Share (If applicable)

Awardee Share (If applicable)

Total (if applicable)

B\&R Number (If applicable)

B\&R Dollars (If applicable)

CICA Applicability

Type of Business

Advisory and Assistance

Number of Offerors

Small Disadvantaged Business

Subcontracting Plan

Type of Award

Competitive Solscitation Procedures 
61

62

63

64

65
Woman Owned

Safety and Health Clause

Competitive Exemption Authority (If applicable)

Preference Program

Subject to Labor Statute

Extent Competed

Hispanic Institution

Product and Service Code

Commercial Items

SIC Code

Synopsis Requirement

Small Business Competitiveness

Demonstration Program

Directed Procurement

Trade Data - Country of

Manufacture (If applicable)

Emerging Small Business (if

applicable)

OSTI Deliverable

Cognizant DOE Office (If Applicable)

Size of Small Business (if applicable)

Research and Development

Cognizent Federal Agency (If Applicable)

Emerging Small Business

Reserve Award (if applicable)

Government Property

EPACT ("A" mods)

Support Service

Multi-Year Award

EPACT Dollars ("A mods) 
REQUIRED ITEMS FOR POST-CICA PROCUREMENT MODIFICATION WITH DOLLARS (A Mods)

\section{IPAR.TTEM}

1
2
3
4
6
7

22

26

27

28

29

30

32

35

38

41

44

50

62

65

\section{IDENTIFICATION}

Add/Change

Award Bin

Modification Number

Kind of Award Action

PR Number

PR Completion

Award Date

Government Share (If applicable)

Awardee Share (If applicable)

Total (If applicable)

B\&R Number (If applicable)

B\&R Dollars (If applicable)

CICA Applicability

Number of Offerors

Competitive Solicitation Procedures

Competitive Exemption Authority (If

applicable)

Extent Competed

Synopsis Requirement

EPACT

EPACT Dollars (If applicable) 
REQUIRED ITEMS FOR POST-CICA PROCUREMENT MODIFICATION

IPAR ITEM

1

2

3

4

6

7

22

32

35

38

41

44
NO DOLLARS (M Mods)

IDENTIFICATION

Add/Change

Award Bin

Modification Number

Kind of Award Action

PR Number

PR Completion

Award Date

CICA Applicability

Number of Offerors

Competitive Solicitation Procedures

Competitive Exemption Aulhority (If

applicable)

Extent Competed 


\section{REQUIRED ITEMS INTERAGENCY AGREEMENT AWARD}

(Type of Insirument Al)

\section{IPAR ITEM}

1

2

3

4

6

7

10

11

12

16

17

18

19

20

21

22

23

25

24

26

27

28

29

30

55

\section{IDENTIFICATION}

Add/Change

Award Bin

Modification Number

Kind of Award Action

PR Number

PR Completion

Vendor ID

Contractor Name (If no Vendor ID)

Division (If no Vendor tD and/or if applicable)

City

State

Zip Code

County (If city in multiple counties)

Congressional District

Country (If applicable)

Award Date

Award Effective Date

Description of Work

Award Completion Date

Government Share (If applicable)

Awardee Share (If applicable)

Tokal (If applicable)

B\&R Number

B\&R Dollars

OSTI Deliverable

Task Orders against interagency agreements require the same data items as interagency agreement, with two exceptions:

Item 8 Master Bin Required

ltem 55 OSTI Deliverable is not allowed 
REQUIRED ITEMS FOR NEW PURCHASE ORDER BASIC AWARD

(Type of instrument AP)

\section{IPAR ITEM}

1

2

3

4

6

7

11

12

16

17

18

19

21

22

23

24

25

26

27

28

29

30

33

39

44

\section{IDENTIFICATION}

Add/Change

Award Bin

Modification Nurnber

Kind of Award Action

PR Number

PR Completion

Contractor Name

Division

City

State

Zip Code

County (If city in multipie counties)

Country (If applicable)

Award Date

Award Effective Date

Award Completion Date

Description of Work

Govemment Share (If applicable)

Awardee Share (If applicable)

Total (If applicable)

B\&R Number (If applicable)

B\&R Dollars (If applicable)

Type of Business

Woman Owned

Extent Competed 
REQUIRED ITEMS FOR NEW FINANCIAL ASSISTANCE AWARD (BASIC AWARD) (A \& M Mods)

\section{IPAR ITEM}

1

2

3

4

5

6

7

8

9

10

11

12

13

14

15

16

17

18

19

22

23

24

25

26

28

29

30

31

32

33

\section{IDENTIFICATION}

Add/Change

Award Bin

Modification Number

Kind of Award Action

PR Number

PR Completion

Vendor ID

Contractor Name (If no Vendor ID)

Division (If no Vendor ID and/or if applicable)

City

State

Zip Code

County (If city in multiple

counties)

Congressional District

Country (if applicable)

Description of Work

Award Date

Award Effective Date

Award Completion Date

Government Share (If applicable)

Awardee Share (If applicable)

Total (If applicable)

B\&R Number

B\&R Dollars

CFDA Number

Category of Borrower (if

applicable)

State Application Identifier

(If applicable)

Legal Address - City

Legal Address - State

Legal Address - Zip Code 
REQUIRED ITEMS FOR NEW FINANCIAL ASSISTANCE AWARD (BASIC AWARD) (A \& M Mads)

34

35

36

37

38

39

40

41

42

43

44

45

46
Legal Address - County

Legal Address -

Congressional District

Type of Awand

Extent of Competition

OSTI Deliverable

Type of Business

Research and Development

Government Property

Hispanic Institution

SBIR

Small Business Technology Transfer

Cognizant DOE Office (if applicable)

Cognizant Federal Agency (if applicable) 
REQUIRED ITEMS FOR FINANCIAL ASSISTANCE MODIFICATION WITH DOLLARS (A Mods)

\section{IPAR ITEM}

1

2

3

4

5

6

17

22

23

24

25

26
IDENTIFICATION

Add/Change

Award Bin

Modification Number

Kind of Award Action

PR Number

PR Completion

Award Date

Government Share (If Applicable)

Awardee Share (If Applicable)

Total (If Applicable)

B\&R Number ( If Applicable)

B\&R Dollars (If Applicable)

REQUIRED ITEMS FOR FINANCIAL ASSISTANCE MODIFICATION NO DOLLARS (M Mods)

\section{IPAR ITEM}

1

2

3

4

5

6

17

\section{IDENTIFICATION}

Add/Change

Award Bin

Modification Number

Kind of Award Action

PR Number

PR Completion

Award Date 


\section{STATE ABBREVIATIONS}

\begin{tabular}{|c|c|c|c|}
\hline AK & Alaska & MS & Mississippi \\
\hline AL & Alabama & MT & Montana \\
\hline AR & Arkansas & NC & North Carolina \\
\hline AS & American Samoa & ND & North Dakota \\
\hline$A Z$ & Arizona & NE & Nebraska \\
\hline CA & California & NH & New Hampshire \\
\hline Co & Colorado & NJ & New Jersey \\
\hline CT & Connecticut & NM & New Mexico \\
\hline DC & District of Columbia & NV & Nevada \\
\hline $\mathrm{DE}$ & Delaware & NY & New York \\
\hline FL & Florida & $\mathrm{OH}$ & Ohio \\
\hline FM & $\begin{array}{l}\text { Micronesia, Federal } \\
\text { State of }\end{array}$ & OK & Oklahoma \\
\hline GA & Georgia & OR & Oregon \\
\hline GU & Guam & PA & Pennsylvania \\
\hline HI & Hawaii & PR & Puerto Rico \\
\hline IA & lowa & PW & Palau Republic of \\
\hline ID & Idaho & RI & Rhode Island \\
\hline IL & Illinois & $\mathrm{SC}$ & South Carolina \\
\hline IN & Indiana & SD & South Dakota \\
\hline KS & Kansas & TN & Tennessee \\
\hline KY & Kentucky & TX & Texas \\
\hline LA & Louisiana & UT & Utah \\
\hline MA & Massachuselts & VA & Virginia \\
\hline MD & Maryland & VI & Virgin Islends \\
\hline ME & Maine & $\sqrt{1}$ & Vermont \\
\hline MH & Marshall Island & WA & Washington \\
\hline MI & Michigan & WI & Wisconsin \\
\hline MN & Minnesota & WN & West Virginia \\
\hline MO & Missouri & WY & Wyoming \\
\hline MP & $\begin{array}{l}\text { Northern Mariana } \\
\text { Islands }\end{array}$ & & \\
\hline
\end{tabular}


COUNTRY CODES

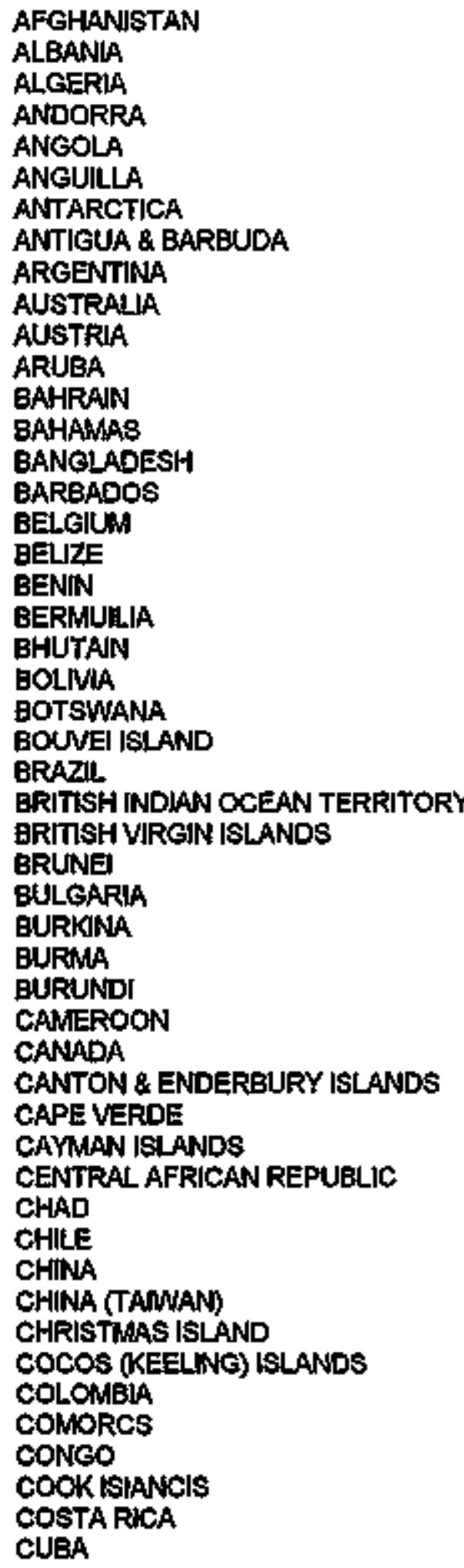

AF

AL

AG

$A N$

AO

AV

AY

AC

AR

AS

AU

AA

$B A$

BF

BG

BB

BE

$\mathrm{BH}$

BN

BD

BT

BL

BC

BV

BR

10

VI

BX

BU

UV

BN

BY

$\mathrm{CM}$

CA

EO

CV

CJ

CT

CD

Cl

$\mathrm{CH}$

TW

KT

CK

co

CN

CF

CW

Cs

cu 
CYPRUS

CZECHOSLOVAKIA

DEMOCRATTC PEOPLES REPUBLIC

OF KOREA

DENMARK

DOMINICA

DOMINICAN REPUBLIC

ECUADOR

EGYPT

EL SALVADOR

ENIWETOK ATOLL

EQUATORIAL GUINEA

ETHIOPIA

FALKLAND ISLANDS (ISLAS MALVINAS)

FAROE ISLANDS

FEDERAL REPUBLIC OF GERMANY

FIJI

FINLAND

FRANCE

FRENCH GUIANA

FRENCH POLYNESIA

FRENCH SOUTHERN \& ANTARCTIC LANDS

GABON

GAMBUA

GERMAN DEMOCRATIC REPUBLIC

GERMANY, FEDERAL REPUBLIC OF

GHANA

GIBRALTAR

GILBERT I\$LANDS

GREECE

GREENLAND

GRENADA

GUADELOUPE

GUATEMALA

GUINEA

GUINEA-BISSAU

GUYANA

HAITJ

HEARD ISLAND \& MCDONALD ISLANDS

HONDURAS

HONG KONG

HINNGARY

ICELAND

INDIA

INDONESIA

IRAN

IRAQ

IRAQ-SAUD ARABIA NEUTRAL ZONE

IRELAND

ISRAEL-

ITALY

NORY COAST
CY

$\mathrm{CZ}$

KN

DA

W

DR

EC

EG

ES

EA

EK

ET

FA

FO

GE

FJ

FI

FR

FG

FP

FS

GB

$G A$

GC

GE

$\mathrm{GH}$

GI

GS

GR

GL

GJ

GP

GT

GV

PU

GY

HA

HM

NO

HK

NU

IC

IN

ID

IR

IZ

IY

EI

IS

IT

N. 
JAMMAICA

JAPAN

JOHNSTON ATOLL

JORDAN

KAMPLCHEA

KENYA

KUWAIT

LAOS

LEBANON

LESOTUO

LIBERIA

LIBYA

LIECHTENSTEIN

LUXEABOURG

MACAL

MADAGASCAR

MALAWI

MALAYSIA

MALDNE

MALI

MALTA

MARTINIOUE

MAURITANIA

MAURITUS

MEXICO

MONACO

MONGOLLA

MONTSERRAT

MOROCCO

MOZAMEIQUE

NAMBIA

NAURU

NEPAL

NETHERLANDS

NEW CALE W NIA

NEW HEBRIDES

NEW ZEALAND

NICARAGUA

NIGER

NIGERIA

NILE

NORFOLK ISLAND

NORWAY

OMAN

PAKISTAN

PANAMA

PAPUA NEW GUINEA

PARACEL ISLANDS

PARAGUAY

PERU

PHIILPPINES

PITCAIRN ISLANDS

POLAND

PORTUGa]

QATAR
JW

JA

JQ

JO

CB

KE

KU

LA

LE

LT

LI

LY

LS

LU

MC

MA

MI

MY

MV

ML

MT

MB

MR

MP

MX

MN

MG

MH

MO

MZ

WA

NR

NP

NL

NC

$\mathrm{NH}$

NZ

NU

NG

NI

NE

NF

NO

MU

PK

PN

PP

PF

PA

PE

RP

PC

PL

PO

$Q A$ 
REPUBLC OF KOREA

KS

REUNION

RE

ROMANIA

RWANDA

RO

SAN MARINO

SAO TOME \& PRINCIPE

RW

SAUDIA ARABMA

SM

TP

SENEGAL

$\mathrm{SA}$

SEYCHELLES

SG

SE

SIERRA LEONE

SL

SINGAPORE

SN

SOLOMON ISLANDS

$\mathrm{BP}$

SOMALIA

so

SOUTH AFRICA

SF

SOUTHERN RHODESIA

RH

SPAN

SPRATLY ISLANDS

SRI LANKA

ST. CHRISTOPHER \& NEVIS

ST. HELENA

ST. LUCIA

ST. PUERRE \& MIQUELON

ST. VNCENT \& THE GRENADINES

SUDAN

SURINAME

SVALBARD \& JAN MAYEN

SWEDEN

SWTZERLAND

SP

PG

CE

SC

sH

\$T

SB

$\mathrm{VC}$

su

NS

JS

SW

SZ

SYRIA

SY

THAILAND

TOBO

TOKELAU ISLANDS

$\mathrm{TH}$

TO

TONGA

TL

TN

TD

TRNIDAD \& TOBAGO

TS

TU

TK

TV

TURKS \& CAICOS ISLANDS

TUVALU

UGANDA

UNION OF SOVIET SOCIALIST

REPUBLICS

UNITED ARAB EMIRATES

UNITED KINGDOM

UNITED REPUELIC OF TANZANIA

UNITED STATES MNOR OUTLYING

ISLANDS

UNITED STATES MISCELLANEOUS

PACIFIC ISLANDS

UG

UR

TC

UK

TZ

UM

IO

URUGUAY

UY 
VANUATU

VATICAN CITY

Vu

VENEZULEA

VIETINAM

WALUS \& FUTUNA

WESTERN SAHARA

WESTERN SAWOA

VT

VE

VM

WF

WI

YEMEN PEOPLE'S DEMOCRA'TIC

WS

REPUBLIC OF

YEMEN

YUGOSLAVA

YS

YE

YO

ZAIRE

ZANBIA

CG

ZMBABWE

ZA

ZW 


\section{INSTRUCTIONS FOR COMPLETING \\ AWARDEE NAMES \\ INPADS}

introduction

The instructions are intended to aid procurement personnel who prepare IPAR forms in entering the name(s) of new awardees in a standardized format. Instruction is also provided for the abbreviation of those names which exceed 30 characters.

Use these instructions whenever the name of the awardee does not appear in the current "Directory of Awardee Names" or its supplement as issued by DOE Headquarters and the Office of Scientific and Technical Information (OSTI).

Attachment 1 to this Appendix contains permissible abbreviations for use in PADS. 


\section{GENERAL}

Field for Awardee Name: This is a fixed field length of thirty $(30)$ alphanumeric characters. The name should be entered in clear text subject to the editing rules which follow. In the event the name must be reduced to meet the allowable field length, this must be done through abbreviation.

Field for Awardee's Division Name: This is also a fixed field length of thirty (30) alphanumeric characters. The editing rules are the same as those for the organization name. See formatting beginning on page 103 for examples.

Description: The name of the actual organization or individual receiving the award.

Always abbreviate the words:

Administration

And

Associates/Associated

Company

Corporation

Incorporation

Limited
To:

Admin

$\&$

Assoc

Co

Corp

Inc

Ltd
Always abbreviate the terms:

Independent School District

Consolidated School District

Unified School District
To:

ISD

CSD

USD

Punctuation: The period, comma, and plus sign ( +$)$ are never used. The slent $(/)$, the number sign (\#), the apostrophe ("), and the hyphen (-) are used only when a part of the true awardee name:

Smith Jones Akers \& Murphy Inc (for Smith, Jones, Akers, and Murphy, Inc, )

AVG Technology Corp

Hi-Tech Laboratories Inc

Winston School District \#50

St Patrick's Hospital

Spacing: Spacing appears when it is a part of the name and between the different words of the whole name:

Jess Howard Electric Co Bishop MoNamara High School 
Articles: The articles "A", "An", and "The" are not used when the article is the first word of the awardee name:

National Security Agency

(for The National Security Agency)

Numbers: Numbers are used only when they are a part of the awardee name.

3M Business Product

Amity Regional School Dist \#5

Abbreviated Names: Abbreviated names will be used only when the actual name exceeds thirty (30) characters. Abbreviations are subject to the following editing rules:

a. Foltow these general rules (in order of precedence):

- Abbreviate the least number of words possible

- Abbreviate the most commonly used word

- Abbreviate from the right side of the name

- Do not abbreviate the first word, if possible

b. Select from the table of permissible abbreviations (Attachment 1). 


\section{A. EORMAT WHEN AWARDEE IS AN ORGANIZATION}

The following rules are specifically for organization names:

a. When states of the United States require abbreviation, always use the 2-character abbreviation. (See Appendix $\mathrm{C}$ for abbreviations)

b. When the actual awardee name contains letters of the alphabet, do space between letters which are initials representing proper names, do not space between letters which are abbreviation for words:

H J Gray \& Assoc

E F Hutton Inc

IBM Corp

YMCA of Greater Boston

c. For awardees whose organization name contains a proper name, do not invert first and last names:

Neil R Gross \& Co inc

C B Anderson Electric Co Williarn Johnson \& Asscc

d. When an ampersand $(\&)$ is included in a name, leave a space on each side of it:

$E G \& G$

Neil R Gross \& Co Ine

e. Invert names of state, city, and town organizations, as follows:

Massachusetts State of

Boston City of

Manchester Town of

Fairfax County of

f. Invert names of State Universities, as follows:

Florida University of

(for University of Florida) 
g. Never include the following words at the beginning of the awardee's name:

Fellows, Regents, Board of Trustees, etc:

\author{
Harvard University \\ (for Fellows of Harvard University) \\ Oregon University of \\ (for the Board of Trustees \\ of the University of Oregon)
}

h. Each State usually publishes a manual, primarily for the use of the State legislature. The books are sometimes referred to as a Blue Book, Legislature Manual, index guide, or chart of validating the true names of State organizations.

1. Names of Independent School Districts will appear as follows: Independent School Dist \# (insert \# - up to 5 spaces long)

j. Independent School District, Consolidated School District, and Unified School District may be abbreviated as ISD, CSD, and USD respectively, for example:

Texarkana ISD

Paradise Valley USD \#40

\title{
B. EORMAT WHEN THE AWARDEE IS AN INDIVIDUAL
}

Awardee nome may consist of the following portions (and in the sequence listed): Surname, Title (if any), First Name, and Middle Initial.

Surname - This portion contains, when present, sumame suffixes, such as $\mathrm{Jr}$, III, etc. which are placed after the sumane.

Title - Titles denote designations added to names of individuals, such as $\mathrm{Dr}$, Re, Col, Bro, etc. use of Mr, Ms, Miss, and Mrs is not a title.

Spacing: Spacing appears when it is a part of the name, as in a compound name which contains a space rather than a hyphen, and between the surname and the surname suffix, between the suffix and the first name, and between the first name and the middle initial.

\section{Examples:}

Van Buren Jr Alfred

A Johnson Jr. Dr. William R

Thompson Ill Herold

O'Kelly Mary Anne 
C. FORMAT WHEN THE AWARDEE IS A U.S. GOVERNMENT AGENCY

When the agency is a government depertment, the name should be inverted. For Department of Transportation, enter Transportation Department of. Other format and editing rules remain the same.

Examples:

National Bureau of Standards

Air Force Department of

National Security Agency

Housing \& Uran Dev. Dept of

D. FORMAT FOR AWARDEE DIVISION FIELD

a. Do not repeat the awardee name, either exactly or in a slightly different format, in the division field.

Incorrect example-

Name: Maryland University of

Division: Maryland State Univ System

Correct Example-

Name: Maryland University of No Division

b. Do not put "Physical Plant", "Office of Sponsored Research", "Office of Contracts \& Grants" elc. in the division field.

c. Do not describe the awardee in the division field.

Incorrect Example-

Name: Sunnyvale Health Spa

Division: For RehabilitationNocational

Correct Example-

Name: Sunnyvale Health Spa

No Division 
d. Do not continue awardee name into the division field. If the name will not fit into the thirty (30) spaces available, it must be shortened through abbreviations.

Incorrect Example-

Name: $\quad$ RAMS Specialized Security Division: Service Inc.

Correct Example-

Name: $\quad$ RAMS Spec Security Svas lnc

e. Do not put street address or the name of a contact person in the division field. This is not a field to use for intemal purposes and should anly be used for functional divisions of the awardee.

f. Do not put the name of specific schools in the division field if an award is to a school systern.

Incorrect Examples-

Neme: $\quad$ Middletown Middle School Dist

Division: Building \#6

Name: $\quad$ Middletown School District

Division: Roosevelt Middle School

g. Do invert the division name and do always abbreviate "Department" to "Dept" when it appears in the division field.

Correct Examples-

Name: Virginia University of

Division: Chemistry Dept of

Name: Howard University

Division: Energy Research Dept

Name: $\quad$ IBM Corp

Division: Aerospace Div of 
PERMISSIBLE ABBREVIATIONS FOR USE IN PADS

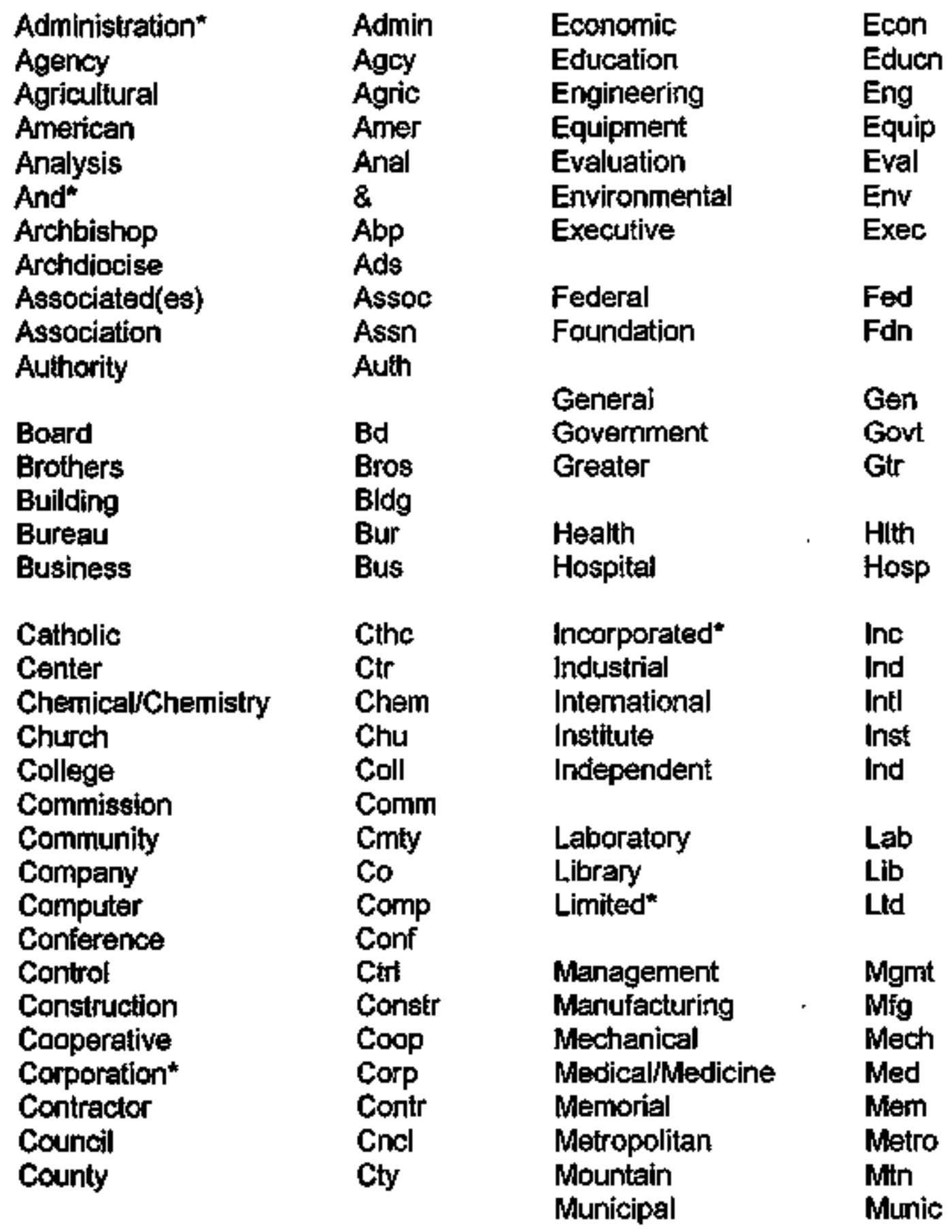




$\begin{array}{llll}\begin{array}{l}\text { Department } \\ \text { Development }\end{array} & \text { Dept } & \text { Netional } & \text { Natl } \\ \begin{array}{l}\text { District } \\ \text { Division }\end{array} & \begin{array}{l}\text { Dist } \\ \text { Div }\end{array} & & \\ \text { Doctor } & \text { Dr } & & \\ & & & \\ \text { Observatory } & \text { Obsv } & \text { Service } & \text { Svc } \\ \text { Office } & \text { Off } & \text { Society } & \text { Soc } \\ \text { Opportunity } & \text { Opp } & \text { State } & \text { St } \\ \text { Organization } & \text { Org } & \text { System } & \text { Syst } \\ & & & \\ \text { Planning } & \text { Plng } & \text { Technical } & \text { Tech } \\ \text { Professional } & \text { Prof } & \text { Technology } & \text { Tect } \\ \text { Program } & \text { Prgm } & \text { Township } & \text { Twp } \\ \text { Project } & \text { Proj } & \text { Training } & \text { Trng } \\ \text { Regional } & \text { Reg } & \text { Unifted } & \text { Und } \\ \text { Research } & \text { Res } & \text { United } & \text { Untd } \\ \text { Reservation } & \text { Resva } & \text { Urited States } & \text { US } \\ \text { University } & \text { Univ } & & \\ \text { Utility } & \text { Util } & & \\ \text { Saint } & & & \\ \text { School } & \text { St } & \text { Vocational } & \text { Voc } \\ \text { Science } & \text { Sch } & & \end{array}$

Notes: (1) An "S" may be added to any appropriate abbreviation to indicate a plural.

(2) Directions should be written as follows:

$\begin{array}{llllll}\text { North } & \text { N } & \text { Northern } & \text { NRN } & \text { Northeast } & \text { NE } \\ \text { South } & \text { S } & \text { Southern } & \text { SRN } & \text { Northwest } & \text { NW } \\ \text { East } & \text { E } & \text { Eastern } & \text { ERN } & \text { Southeast } & \text { SE } \\ \text { West } & \text { W } & \text { Western } & \text { WRN } & \text { Souttwest } & \text { SW }\end{array}$

* Indicates those words which should always be abbreviated. 


\section{APPENDIX F}

\section{Historically Black Colleges and Universities}

Historically black colleges and universities (HBCU) are defined as any historically black college or university that was established prior to 1964 , whose principal mission was, and is, the education of black Americans, and that is accredited by a nationally recognized accrediting agency or association determined by the Secretary of Education to be a reliable authority as to the quality of training offered or is, according to such an agency or association, making reasonable progress toward accreditation.

\section{Minority Institution}

Minority Institution means an institution of higher education whose enrollment of a single minority or combination of minorities exceeds 50 percent of the total enrollment. The term "minority" means American Indian, Alaskan Native, Black (not of Hispanic origin), Hispanic (including persons of Mexican, Puerto Rican, Cuban, and Central or South American origin), Pacific Islander or other ethnic group underrepresented in science and engineөring. Minority institution also includes an Hispanic-serving institution which is defined as an institution which (1) has enrollment of undergraduate full-time equivalent students that is at least 25 percent Hispanic students; and (2) provides assurances that not less than 50 percent of its Hispanic students are low-income individuals who are first generation college students and another 25 percent of its Hispanic students are either low-income individuals or first generation college students. First generation college student means an individual both of whose parents did not complete a baccalaureate degre日, or in the case of any individual who, regulariy resided with and received support from only one parent, an individual whose only such parent did not complete a baccalaureate degree. Low income individual means an individual from a family whose taxable income for the preceding year did not exceed 150 percent of an amount equal to the poverty level determined by using criteria of poverty established by the Bureau of the Census, 
Historically Black Colleges and Universities

The following is a list of the Historically Black Colleges and Universities (HBCU's):

Alabama

Alabama A\&M University

Alabama State University

Bishop State Community College

Concordia College

Fredd State Technical College

Lawson State Community College

Miles College

Oakwood College

Selma University

J.F. Drake Technical College

Stillman College

Talladega College

Trenholm State Technical

Coilege

Tuskegee University

Arkansas

Arkansas Baptist College

Philander Smith College

Shorter College

University of Arkansas/Pine

Bluरff

\section{Delaware}

Delaware State University

District of Columbia

Howerd University

University of the District of

Columbia

Florida

Bethune-Cookman College

Edward Waters College

Florida A\&M University

Florida Memorial College

Georgia

Albany State College

Clark Atlanta University
Georgia (cont'd)

Paine College

Savannah State College

Spelman College

Kentucky

Kentucky State University

Louisiana

Dillard University

Grambling State University

Southem University A\&M

College

Southern University at New

Orieans

Southern University at

Shreveport/Bossier City

Xavier University

Maryland

Bowie State University

Coppin State College

Morgan State University

University of Maryland

Eastern Shore

Michigan

Lewis College of Business

Mississippi

Alcorn State University

Coahoma Community College

Jackson State University

Mary Holmes College

Mississippi Valley State

University

Rust College

Tougaloo College 
Fort Valley State College

Interdenominational

Theological Center

Morehouse College

Morehouse School of Medicine

Morris Brown College

North Carolina

Baber-Scotia College

Bennett College

Elizabeth City State University

Fayetteville State University

Johnson C. Smith University

Livingstone College

North Carolina A\&T State

University

North Caclina Central

University

Saint Augustine College

Shaw University

Winston-Salem State University

Ohio

Central State University

Wilberforce University

Qklahoma

Langston University

Pennsylvania

Cheyney State University/PA

Lincoln University

South Carolina

Allen University

Benedit College

Claflin College

Clinton Junior College

Denmark Technical College

Morris College

South Carolina State University

Voorhees College
Missouri

Harris-Stowe State College

Lincoln University

Tennesseg

Fisk University

Knoxville College (Knoxville

And Morristown Campuses)

Lane College

Lemoyne-Owen Cotlege

Meharry Medical College

Tennessee State University

Texas

Huston-Tillotson College

Jarvis Christian College

Paul Quirn College

Prairie View A\&M University

Saint Phillip's College

Southwestern Christian College

Texas College

Texas Southem University

Wiley College

Virginia

Hampton University

Norfolk State University

Saint Paul's College

Virginia State University

Virginia Union University

West Virginia

Bluefield State College

West Virginia State University

U.S. Virgin Islands

University of the Virgin

Islands (St. Thomas Campus) 


\section{5-1996 UNITED STATES DEPARTMENT OF EDUCATION \\ APPENDIX F (Con't) \\ U.S. ACCREDITED POSTSECONDARY MINORITY INSTITUTIONS ${ }^{1}$}

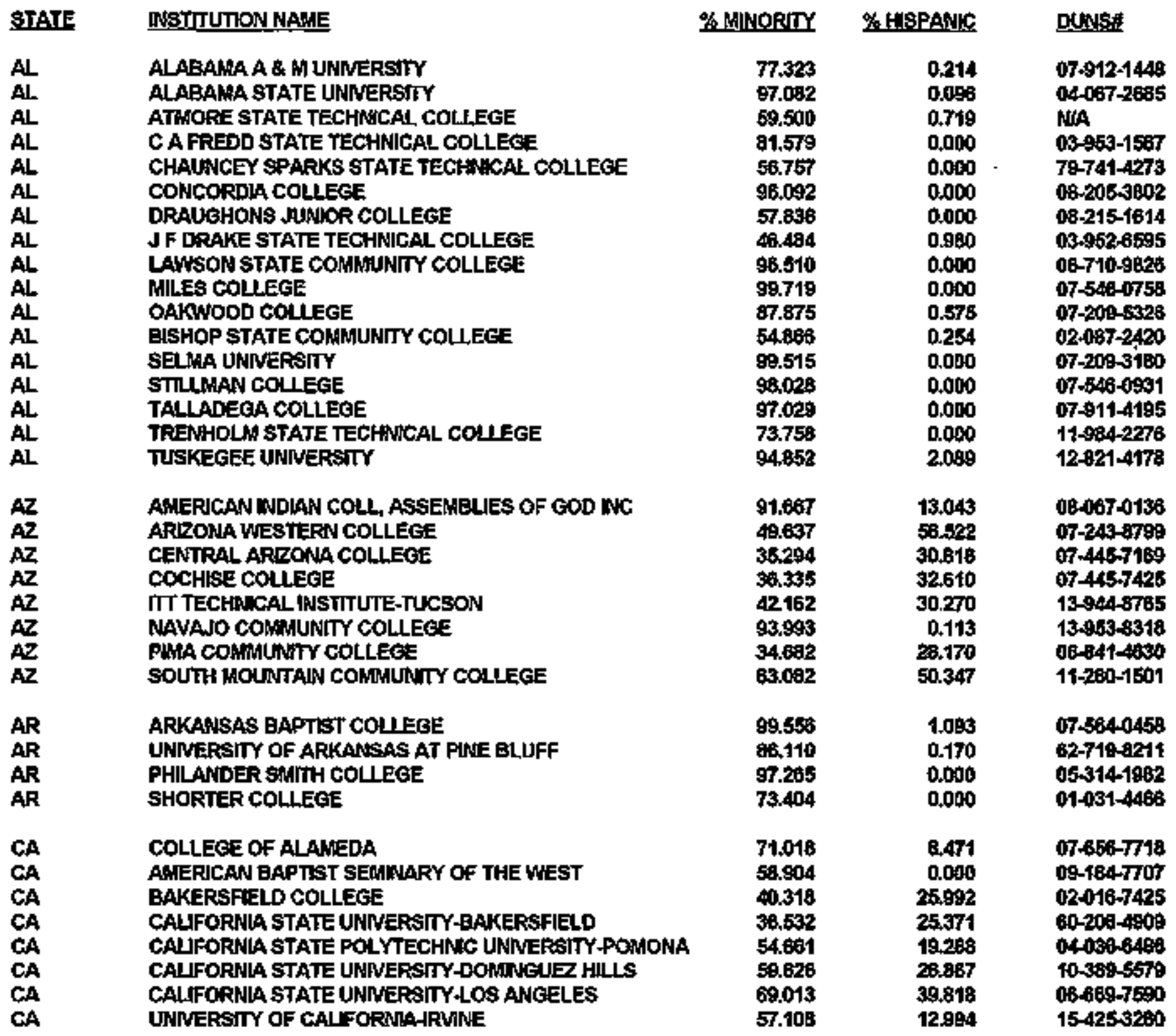

I Data is obtained by the Office for Civil Rights, U.S. Department of Education from information provided by responding instituttons in the 1994 Integrated Postsecondary Education Data System (IPEDS) Fall Enrollment Compliance Report to the Ofice for Civil Rights (OCR) and the National Center for Editcation Statistics. Percentage minority students is derived from reported total student enrollment (IPEOS line 29), whereas percentage Hispanic students is derived from reported total futl-tine undergraditate enrollment (IPEDS fine 8).

Identification of minority institutions by OCR pursuant to $\$ 1135 \mathrm{~d}-5(3)$, Education Amendments of 1986 to the Higher Education Act of 1965. Identification of Hispanic-serving Institutions pursuant to \$ 302 (d) (1) of Pubulc Law 102-325 (20 U.S.C. 1059c), most fecently amended December 20, 1993, in \$ 2(a)(7) of P.L. 103-206.

The _ symbol identifies Historically Black Colleges and Lntversities described in Amendments to Titte III, § 301 of P.L. 96-374

(20 U.S.C. 1061), Higher Education Act of 1965, and most recently amended December 20, 1993, in § 2(m) of P.L. 103-200. 
STATE DNSTIUTION MAME

CA

$C A$

CA

CA

CA

CA

CA

CA

CA

CA

CA

CA

CA

CA

CA

CA

CA

GA

CA

CA

CA

CA

CA

CA

CA

CA

CA

$\mathrm{CA}$

CA

CA

CA

CA

GA

CA

CA

CA

CA

CA

CA

CA

$\mathrm{CA}$

CA

CA

CA

CA

CA

CA

CA

CA

CA

CA

$\mathrm{CA}$

CA

CA

CA

CA

CA

CA

CA

CA

CHABOT COLLEGE

CITRUS COLHECE

DA UNIERSTTY

GAVILAN COLLECE

LANEY COLLEGE

MERCED COLLEGE

MERPIT COULEE

MISSION COUECE

OXNARD COLLECE

SKYUKE COUEGE

VENTURA COLLECE

WHITTER COLLEGE
UNNERSITY OF CALFORNLA-LOS ANGELES

UNNERSTY OF CALIFORNLANWERSTEE

CERRTTOS COLLECE

CHAFHEY COMMUNTY COLLEGE

CONTRA COSTA COLLEGE

DGVRY HWTITUTE OF TECHNOLOGYPOHONA

DON BOSCO TECHNICAL INSTITUTE

EAST LOS ANGELES COLLEGE

PHAll.JPS JUNIOR COLLEGE

EL CAMHO COLLEGE

EVERGREEN VALLEY COLLEGE

FRESNO CITY COUEGE

HARTTEL COLUEGE

HEALD BUSNESS COULEESAN FRANCISCO

IMPERIAL VALLEY COLLEGE

ITT TECHA:CAL INSTTUTESAN DIEEO

ITT TECHNCAL IHSTTUTE-MEST COVNA

ITT TECHNCAL NNSTTUTE-ANAHTEIM

HWES RUVER COWMUNTY COLLEGE

LA SEERRA UNNEREITY

LONG BEACH CITY COLLEGE

LOS ANCELES HAREDR COLLECE

LOS ANGELES SOUTHWEST COLLEGE

LOS ANGELES TRADE TECHNICAL COLLEGE

LOS ANGELES CITY COLLEGE

LOS ANGELES MISSIDN COUEGE

MT BAN ANTONIO COLEGE

MOUNT SAINT HARYS COLLGE

PHILLPS COUEGE IHLAND EMPPIRE CAMPUS

PALO VERDE COLLEEGE

PABADENA CITY COLLEGE

PORTERVIUE COLLEGE

RANCHO SANTLAGO COLLEGE

FIO HONDO COLLEE

SAN DIEGO CITY COLLEEE

SAW JOSE CIT COUEGE

SAWNER COLEEE AT VENTURA

COLLEGE OF THE SEAUOHAS

SAN BERJUARDNNO VALLEY COLLEGE

SOUTH BAYLO UNVWERTIY

SOUTHANESTERH COULECE

WEST HLLS COHWUNITY COLEEGE

WEST LOS ANGEIFS COLLEGE

WOODEURY UNTIEFSTY

FASHION INSTITUTE OF DESHEN AND MERCHSAN DEGO

PHILUPS JUFOR COLLEeE

ITT TECHNICAL WSTIUTE-CARSON

IIT TECHNICAL_ IISTITUTE-SAN BERNARDINO
\%H.YORTY

51,831

sit 17

然,

52.867

48.448

46.98

63.547

79.614

62.531

90,032

69.362

69.131

57.814

63.680

48,998

45.029

59,214

73.004

70.016

42683

75761

53.582

47.255

72421

51.560

59112

62153

93.82

84.658

63.001

70,321

44.624

65.672

62.005

60.523

50.142

E5.681

64.136

49.127

65794

42.208

50.655

77.630

54.032

54.864

58.687

41.943

60.412

58.737

76.344

73.445

34183

45.768

74091

35914

46.422

47.907

87.394

83.449

52.548
\%HISPANIC

15.941

16,498

37.240

14.377

25814

26.424

12955

6.716

33.067

73.196

67.577

59.217

17.666

22508

25.949

39.649

48.922

20.374

83.193

20.340

84.675

35.100

44399

8.104

19,895

20 e02

आग.565

20.174

4. 424

25.251

64.119

28.607

8.683

12721

29.705

42435

33.180

56.652

46.976

21.523

30064

32.431

60.800

23.033

22.822

45.763

34.005

24730

29.003

0.000

54.209

28.343

33.465

15.6k2

27.019

260183

27.434

39,336

48.955

37.580

DUN혀ㄴㅛㅛ

10.300-1912

17-384-2235

07-189-6773

07-169-0961

$07408-4926$

06-627-2R59

A2-804-1339

07-153-8110

15-839-7204

01-071-4723

60-807-1973

08-290-6371

$80-400-2674$

$02-927-6342$

96-866-9734

15-930-989B

08-701-65J6

$071-06-8968$

078-74-5197

12-041-9239

065-12-7243

05-470-1560

0\%B-86-9734

076-56-7718

627-69.098s

072-31-6698

133-29-4884

$072-26-6174$

$042-40-4848$

021-079-9900

080-07-3835

074-68-7072

$07+656-7 / 1 B$

09-554-1279

07-722-8344

059-92-7150

of $791-6482$

03-085-23:B

o7 -405-1683

09-219-6171

$02016-7425$

07-607-0283

$07-0849124$

of $335-7048$

$02-927-6342$ 


\begin{tabular}{|c|c|c|c|c|}
\hline STATE & NSTRUMON NAME & MORTY & \% HSPANE & DUNSE: \\
\hline $\begin{array}{l}c 0 \\
c o \\
c o \\
c o \\
c o\end{array}$ & $\begin{array}{l}\text { ADAMS STATE COUEGE } \\
\text { COWWUNTY COLLEGE OF DENVER } \\
\text { OTERO JUNIOR COLLEE } \\
\text { PUEELO COMWUNTY COLLEGE } \\
\text { TRINIDAD STATE JUAOR COLLEGE }\end{array}$ & $\begin{array}{l}19.149 \\
49.531 \\
33.303 \\
35.975 \\
41.912\end{array}$ & $\begin{array}{l}27.157 \\
25.546 \\
27.031 \\
35.240 \\
36.490\end{array}$ & $\begin{array}{l}04-070-5899 \\
79-549-3709 \\
09-949-8182 \\
79-625-9709 \\
13-821-5204\end{array}$ \\
\hline $\begin{array}{l}\text { CT } \\
\text { CT }\end{array}$ & $\begin{array}{l}\text { CAPTAL CONMUNTY-TECHNICAL COLLEGE } \\
\text { HOUSATONC COMMUNITY-TECHW"CAL COLEGE }\end{array}$ & $\begin{array}{l}51.362 \\
49.442\end{array}$ & $\begin{array}{l}23.123 \\
25.105\end{array}$ & $\begin{array}{l}80.696-2927 \\
07-540-8427\end{array}$ \\
\hline DE & DELAWARE STATE UNNEREITY & 02767 & 1.600 & $11-433-7629$ \\
\hline $\begin{array}{l}\text { DC } \\
\text { DC } \\
\text { DC } \\
\text { DC } \\
\text { OC }\end{array}$ & $\begin{array}{l}\text { UNMERSTY OF THE OISTRCT OF COLUMBUA } \\
\text { HOWARD UNNERSITY } \\
\text { STRAYER COLLEGE-WASHINGTON CAMPUS } \\
\text { TFWTY COUEGE } \\
\text { STRAYER COLLEGE-TAKOMA PARK CAMPUS }\end{array}$ & $\begin{array}{l}86.099 \\
91.351 \\
74.634 \\
68.618 \\
70.695\end{array}$ & $\begin{array}{l}3.027 \\
0.471 \\
2.931 \\
8.333 \\
4.947\end{array}$ & $\begin{array}{l}13-746-0275 \\
05.628-22196 \\
06-939-0469 \\
07-481-0110 \\
06-939-0466\end{array}$ \\
\hline $\begin{array}{l}\text { FL } \\
\text { FL } \\
\text { FL } \\
\text { FL } \\
\text { FL } \\
\text { FL } \\
\text { FL } \\
\text { FL } \\
\text { FL } \\
\text { FL } \\
\text { FL } \\
\text { FL } \\
\text { FL } \\
\text { FL } \\
\text { FL } \\
\text { FL }\end{array}$ & 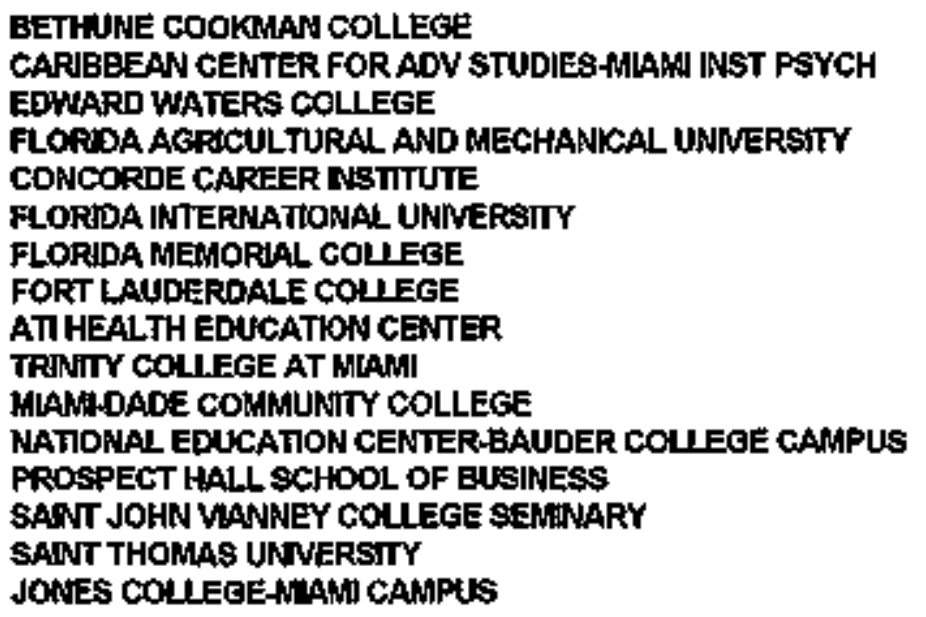 & $\begin{array}{l}94.840 \\
84.683 \\
94.628 \\
90.006 \\
68.150 \\
63.751 \\
92956 \\
50.889 \\
77.674 \\
64.402 \\
78.704 \\
59.816 \\
69.822 \\
54.348 \\
59.494 \\
81.9100\end{array}$ & $\begin{array}{r}0.493 \\
42.657 \\
\\
1.241 \\
6.557 \\
50.136 \\
4.813 \\
9.391 \\
18.140 \\
30.078 \\
54.969 \\
22,393 \\
15.120 \\
50.000 \\
44.689 \\
58,974\end{array}$ & $\begin{array}{l}07-831-5919 \\
061-52-1597 \\
06-691-6280 \\
05-441-3125 \\
09-852-8367 \\
07-129-8614 \\
07-727-3581 \\
18-156-0335 \\
18-290-5621 \\
07-727-0056 \\
07-312-4249 \\
07-129-0571 \\
07-222-7994 \\
13-493-1427 \\
07-221-4760 \\
93-8447679\end{array}$ \\
\hline $\begin{array}{l}G A \\
G A \\
G A \\
G A \\
G A \\
G A \\
G A \\
G A \\
G A \\
G A \\
G A \\
G A \\
G A \\
G A \\
G A \\
G A \\
G A \\
G A \\
G A \\
G A \\
G A \\
G A \\
G A \\
G A\end{array}$ & 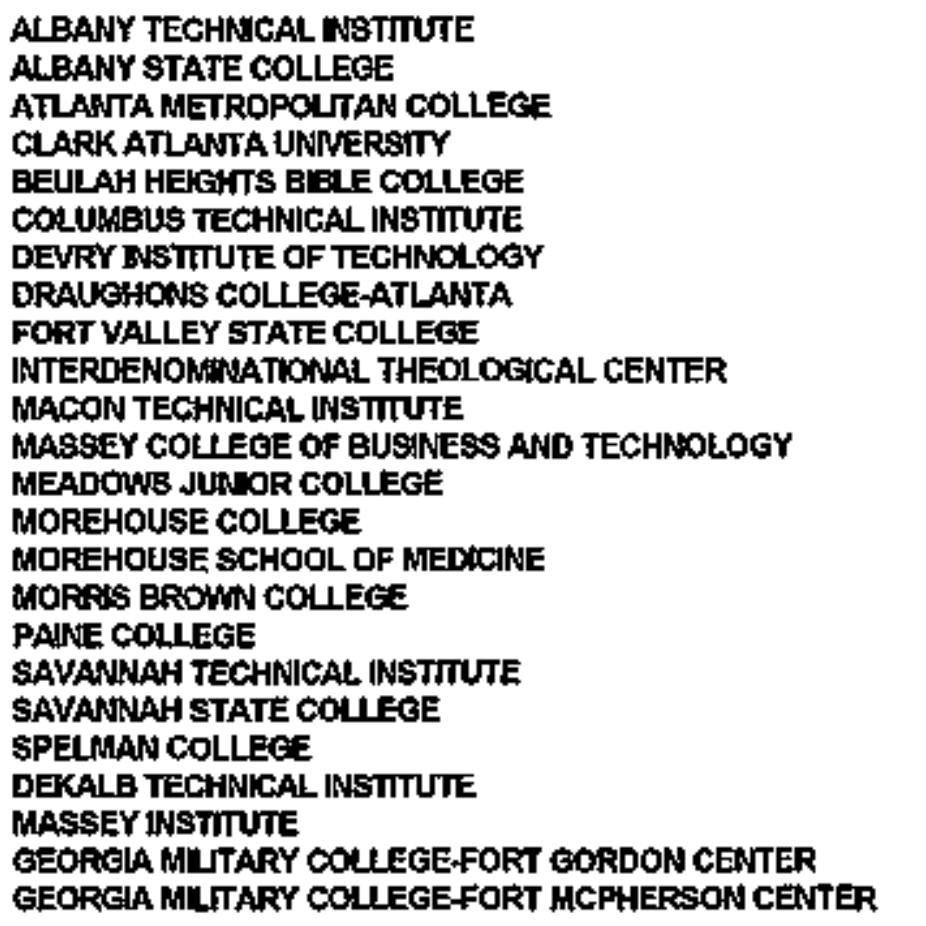 & $\begin{array}{l}56.2968 \\
88.831 \\
94.368 \\
96.726 \\
81.849 \\
\mathbf{9 7 . 2 7 0} \\
65.083 \\
98.095 \\
93.411 \\
93.719 \\
54.351 \\
79.560 \\
70.589 \\
99.766 \\
92073 \\
91.605 \\
98.197 \\
55.127 \\
91.331 \\
95.802 \\
69.033 \\
70.000 \\
69.540 \\
69.474\end{array}$ & $\begin{array}{l}0.405 \\
0.088 \\
0.302 \\
0.080 \\
0.000 \\
3.713 \\
2612 \\
1.905 \\
0.136 \\
0.000 \\
0.185 \\
0.000 \\
9.0102 \\
0.000 \\
0.000 \\
0.055 \\
\\
2.444 \\
0.290 \\
0.053 \\
1.891 \\
3.125 \\
3.059 \\
0.439\end{array}$ & 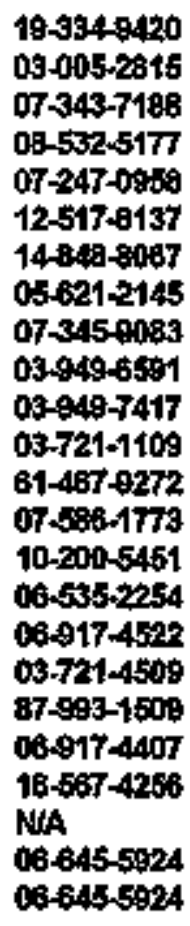 \\
\hline $\begin{array}{l}\text { HI } \\
\text { HI } \\
\text { HI } \\
\text { HI } \\
\text { HI }\end{array}$ & 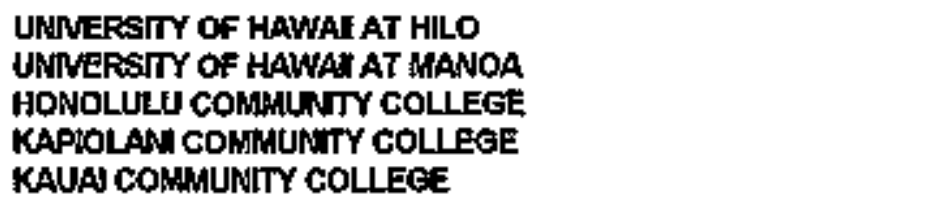 & $\begin{array}{l}56.980 \\
65.017 \\
84.370 \\
78.504 \\
68.972\end{array}$ & $\begin{array}{l}2.075 \\
0.231 \\
2.216 \\
1.408 \\
2.080\end{array}$ & $\begin{array}{l}19-475-6957 \\
70-341-474 t \\
12-017-4081 \\
19-498-8858 \\
06-290-7969\end{array}$ \\
\hline
\end{tabular}




\begin{tabular}{|c|c|c|c|c|}
\hline STATE & NOTIUTONNAME & NORTYY & \%HSPANKC & 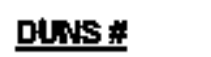 \\
\hline $\begin{array}{l}\mathrm{HI} \\
\mathrm{HI} \\
\mathrm{HI} \\
\mathrm{HI} \\
\mathrm{HI}\end{array}$ & $\begin{array}{l}\text { LEEWAPO COMMUNITY COUEGE } \\
\text { MAUII COMNUNTY COLLEE } \\
\text { UNWERSTY OF HAWAII AT WEST OAHU } \\
\text { WWWWAFO COWMUNTY COUEGE } \\
\text { HAWAI COMMUNTY COLLEGE }\end{array}$ & $\begin{array}{l}79.699 \\
59.502 \\
67.608 \\
63.780 \\
68.668\end{array}$ & $\begin{array}{l}2.348 \\
1.638 \\
1.754 \\
2.796 \\
1.947\end{array}$ & $\begin{array}{l}06-290-9025 \\
08-455-6893 \\
00-943-8664 \\
09-929-9658 \\
07-769-0025\end{array}$ \\
\hline $\begin{array}{l}\mathbb{1 L} \\
\mathbb{L} \\
\mathbb{L L} \\
\mathbb{L} \\
\mathbb{L} \\
\mathbb{L} \\
\mathbb{L} \\
\mathbb{L} \\
\mathbb{L} \\
\mathbb{L} \\
\mathbb{L} \\
\mathbb{L}\end{array}$ & 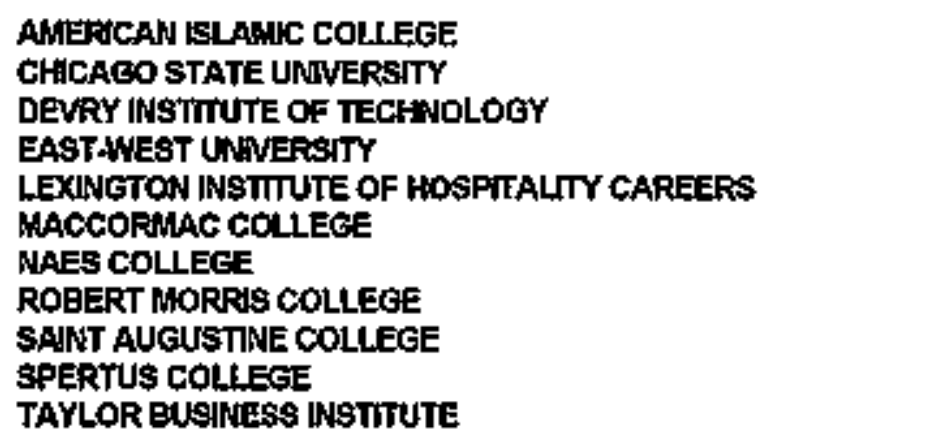 & $\begin{array}{l}59.615 \\
99.691 \\
68.647 \\
86.633 \\
\$ 1.282 \\
42.017 \\
96.117 \\
70.074 \\
98.683 \\
58.685 \\
\$ 6.909\end{array}$ & $\begin{array}{r}0.000 \\
3.904 \\
23.478 \\
6.593 \\
26.471 \\
46.545 \\
0.000 \\
28.445 \\
95.991 \\
33.333 \\
24.4066\end{array}$ & $\begin{array}{l}05-232-6394 \\
10-8109182 \\
06-998-2445 \\
03-760-6936 \\
10-392-3679 \\
83-531-2000 \\
03-963-3904 \\
93-279-6681 \\
01-096-1209 \\
06-951-2418 \\
15-277-5961\end{array}$ \\
\hline IN & MARTNN UNNUERSTYY & 88.109 & 1.235 & 18-947-4215 \\
\hline $\mathbf{A}$ & DVINE WORD COLLEGE & 64.108 & 4064 & $02 \cdot 168.4295$ \\
\hline $\begin{array}{l}\text { KS } \\
\text { KS }\end{array}$ & $\begin{array}{l}\text { DONNELY COUEGE } \\
\text { HASKELL INDAN JUNIOR COLLECE }\end{array}$ & $\begin{array}{r}61.0 \mathrm{~s} \\
100.090\end{array}$ & $\begin{array}{r}11.044 \\
0.000\end{array}$ & $\begin{array}{l}09-035-6581 \\
09-653-4144\end{array}$ \\
\hline $\mathbf{K Y}$ & KENTUCKY STATE UNWERSTY & 49.044 & & 07.131 .7788 \\
\hline $\begin{array}{l}\text { LA } \\
\text { LA } \\
\text { LA } \\
\text { LA } \\
\text { LA }\end{array}$ & $\begin{array}{l}\text { DIUARD UNNERSTY } \\
\text { GRAMBLING STATE UNNEREITY } \\
\text { SOUTHERN UNNERSTY AND A \& N COLLEEE-BATON ROUGE } \\
\text { SOUTHERN UNNERSIY NEW ORLEANS } \\
\text { SOUTHERN UNNERSTY-SHREVEPORT-BOSSER CITY CAMPUS } \\
\text { XAWER UNNERSITY OF LOUISLANA. }\end{array}$ & $\begin{array}{l}\$ 9.5222 \\
95.296 \\
93.942 \\
93.445 \\
93.133 \\
92.377\end{array}$ & $\begin{array}{l}0.062 \\
0.091 \\
0.154 \\
0.323 \\
0.114 \\
0.492\end{array}$ & $\begin{array}{l}06-256-6468 \\
09-544-2083 \\
00-820-1410 \\
10-819-3707 \\
06-703-0783 \\
62-724-7844\end{array}$ \\
\hline $\begin{array}{l}M D \\
M D \\
M D \\
M D \\
M D \\
M D \\
M D\end{array}$ & 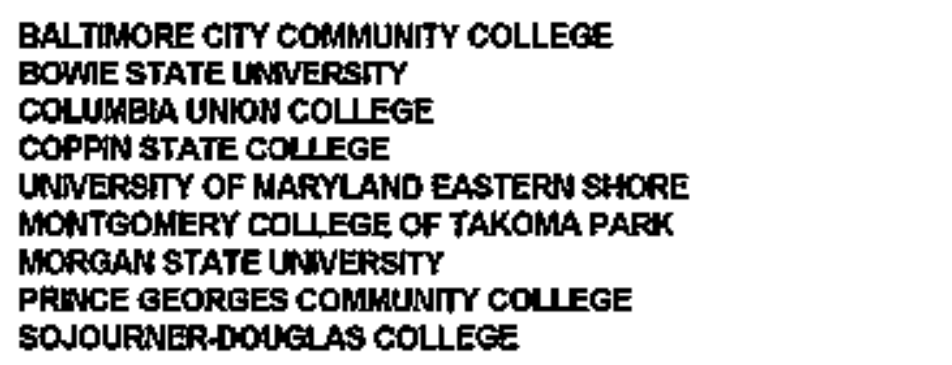 & $\begin{array}{l}85.446 \\
76.430 \\
51.481 \\
94.320 \\
71.795 \\
80.707 \\
94.207 \\
69.398 \\
99.536\end{array}$ & $\begin{array}{l}0.350 \\
0.732 \\
6.029 \\
0.510 \\
0.656 \\
6.234 \\
0.282 \\
3.178 \\
0.000\end{array}$ & $\begin{array}{l}05-035-9092 \\
07-779-1614 \\
00-323-8474 \\
11-973-4867 \\
08-261-1302 \\
08-105-9602 \\
87-994-1318 \\
07-461-9046 \\
07-494-6076\end{array}$ \\
\hline MA & $\begin{array}{l}\text { FRANKLN INSTITUTE OF BOSTON } \\
\text { ROXBURY COMNUNITY COLLEGE }\end{array}$ & $\begin{array}{l}50,448 \\
79.365\end{array}$ & $\begin{array}{r}6.645 \\
24.975\end{array}$ & $\begin{array}{l}07-57-28 B 2 \\
87-804-3413\end{array}$ \\
\hline $\begin{array}{l}\text { MI } \\
\text { MI } \\
\text { All } \\
\text { MI } \\
\text { MI } \\
\text { MI }\end{array}$ & 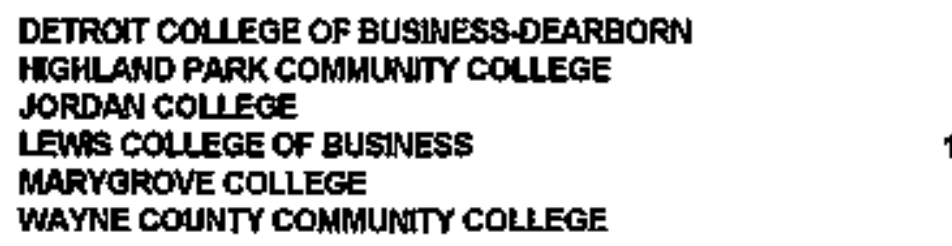 & $\begin{array}{r}50.250 \\
89.432 \\
64.547 \\
100.000 \\
77.094 \\
68.903\end{array}$ & $\begin{array}{l}3.739 \\
0.493 \\
1.342 \\
0.000 \\
1.089 \\
1.246\end{array}$ & $\begin{array}{l}07-424-8246 \\
06-558-0292 \\
19-494-5 \$ 01 \\
09-801-5233 \\
07+40-5059 \\
07-638-6556\end{array}$ \\
\hline $\begin{array}{l}\text { MN } \\
\text { MN } \\
\text { MN } \\
\text { MNN } \\
\text { MNS } \\
\text { MN } \\
\text { MNN }\end{array}$ & 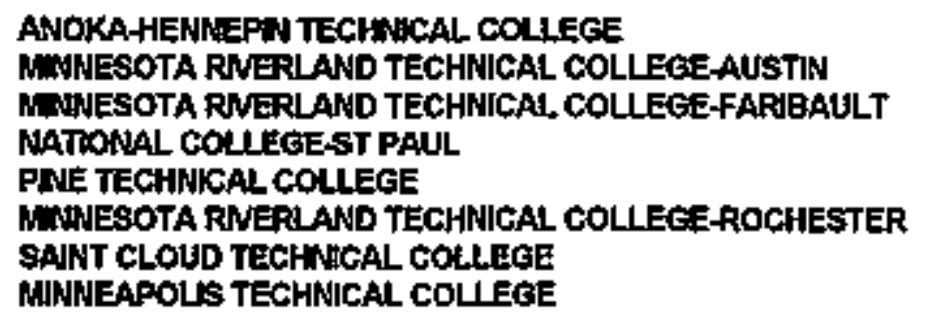 & $\begin{array}{l}49.474 \\
99.420 \\
99.337 \\
54.497 \\
90.326 \\
97.341 \\
98.734 \\
68.697\end{array}$ & $\begin{array}{r}84.727 \\
84.507 \\
94.855 \\
0.685 \\
86.633 \\
98.207 \\
95.442 \\
52.140\end{array}$ & $\begin{array}{l}\text { NAA } \\
17-018-9989 \\
12-396-0391 \\
12-053-2973 \\
13-494-9577 \\
93-581-4081 \\
12-028-7222 \\
10-470-9407\end{array}$ \\
\hline MS & ALCORN STATE UNMERSTY & 93.664 & 0.000 & $07-50 \mathrm{~B}-4697$ \\
\hline
\end{tabular}




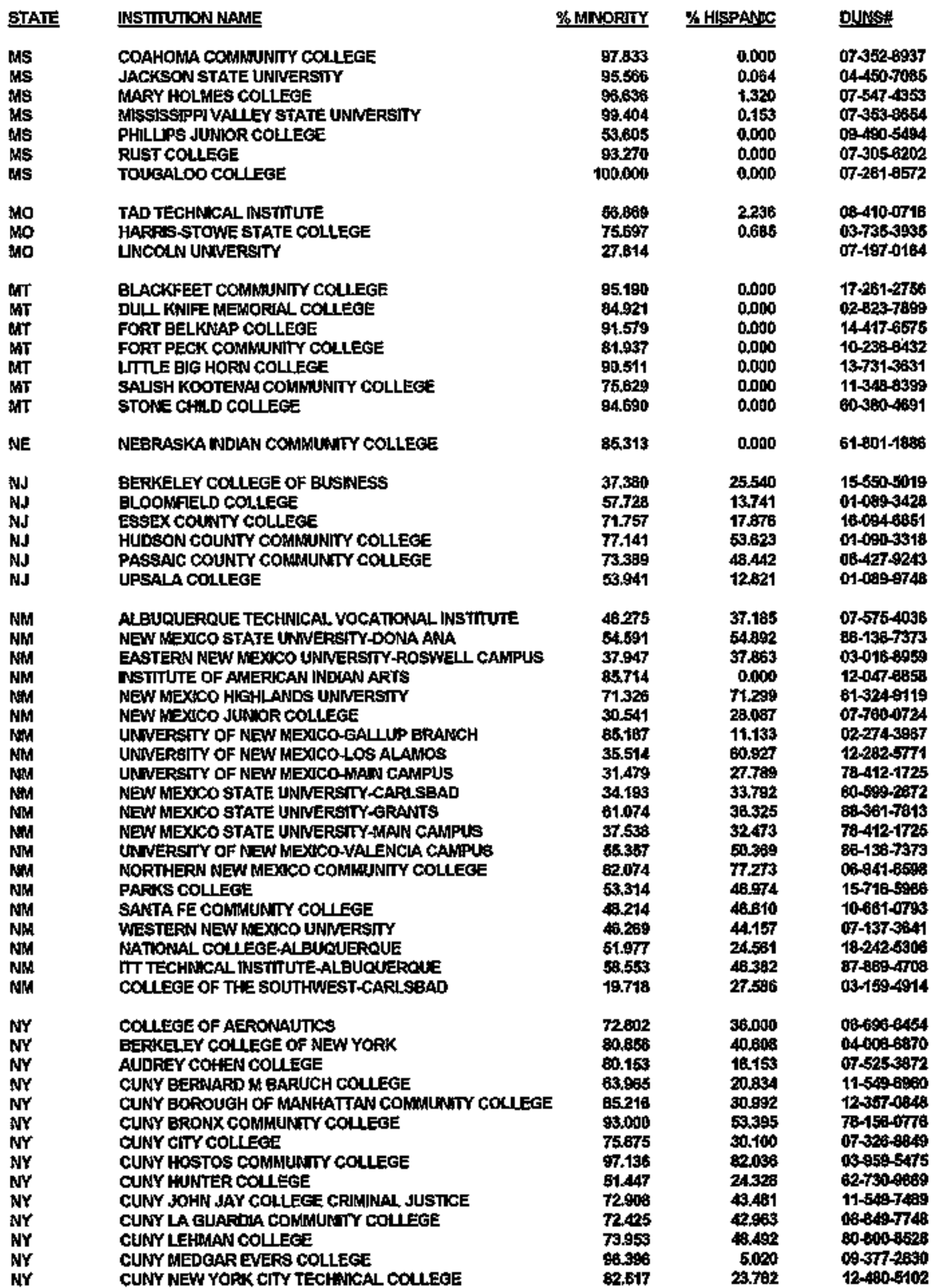




\section{\% MINORTY}

NY

NY

NY

NY

NY

NY

NY

NY

NY

NY

NY

NY

NY

NY

NY

NY

NY

NC

NC

NC

NC

NC

NC

$\mathrm{NC}$

NC

NC

NC

NC

NC

NC

$\mathrm{NC}$

ND

ND

ND

ND

ND

애

에

OK

OK

OR

PA

PA

PA

PA

PA

PA

PA

PA

PA

sc

sc

$\mathrm{sc}$

$8 c$

sc

SC

sc

CUNY QUEENSBOROUGH COMMUNTY COLEGE

CUNY YORK COLLEGE

HELENE FULD SCHOOL OF NURSING

INSTITUTE OF DESIBN AND CONSTFUCTON

INTERBORO WSTTTUTE

LONG ISLAND UNAERSITY-BROOKLYN CAMPUS

LONO ISLAND COLLEGE HOSPITAL SCHOOL OF NURSING

MONROE COLLEGE MAIN CAMAPUS

COUEGE OF NEW ROCHEHE

NEW YORK THEOLOGICAL SEMINARY

PLAZA BUSNESSS INSTITUTE

SANT JOSEPHS COLLEGE-MAN CAMPUS

STENOTYPE ACADEMY

TAYLOR BUSNNESS INSTTIUTE

TECHNICAL CAREER INSTITUTES

WESTCHESTER BUSINESS INSTTIUTE

WOOD TOEE-COBURN SCHOOL

GARBER-SCOTIA COLLEGE

BENNETT COLLEGE

EDGECOMBE COMNUNTYY COLLEGE

ELRABETH CITY STATE UNMERSTY

FAYETTEVILIE STATE UNWERIITY

JOHNSON C SMITH UNNERSITY

ININGSTONE COLLEGE

NORTH CAROLLNA AGRTCULTURAL AND TECHNICAL ST UNNN

NORTH CAROLVA CENTRAL UNNERSITY

ROANOKE-CHOWAN COMMUNTY COLEGE

ROBESON COMMUNITY COLLEGE

SAINT AUGUSTNES COLLEGE

SHAW UWVERSTY

WINSTONSALEM STATE UNNERSTY

FORT BERTHOLD COMMUATY COLLEGE

UTTLE HOOP COMMUNTY COUEGE

STANDNIG ROCK COLLEGE

TURTLE MOUNTAIN COMMUNITY COLLEGE

UNITED TRIBES TECHNCAL COUEGE

CENTRAL STATE UNIVERSTY

MLEERFORCE UNNERSTY

BACONE COLECE

LANGSTON UNNERSTY

MOUNT ANGEL SEMANARY

AMERICAN INSTITUTE OF DESIGN

BEREAN INSTITUTE

CHEYNEY UNNERSTY OF PENNSYLVANA

FATTH THEOLOGICAL SEMINARY

LUCOLN GANERSTY

MCCARPLE SCHOOL OF HEALTH SCIENCES AND TECHN MC

ORLEANS TECHMCAL MUSTIUUTE

PERCE COLLEGE

CONAIUNTY COLLECE OF PYILADELPH:A

ALLEN UAMVRSTY

BENEDICT COLLEEE

CLAFLN COLLECE

CLNTON JUNHOR COLLEOE

DENMARK TECHNICAL COLHEGE

MORESS COLLEGE

NIELSEN ELECTRONCS NSTITUTE
54.399

84.439

88.601

56.333

90.191

58.296

63.243

81785

68.539

72.810

82137

50,484

63,991

63.090

80.534

50.857

77.994

99.537

98.779

52781

74.986

69.2318

$\$ 9.929$

99.781

86.201

25.049

56.250

61.561

88.864

$\$ 6.423$

77.530

68.872

86.207

92.347

67.521

93.902

po.879

97.131

58.127

59.008

20.667

68.702

99.166

\$.979

95,000

91.247

58.933

51,403

65.753

87.673

100,000

97.535

$98,33 \times 3$

20.113

93.452

99.775

76.744

\section{\% Hispantc}

19.380

19.352

0.820

20.888

19.794

15.639

12727

44.988

16.938

0,000

40.989

10.845

19.395

20.600

29.159

21.644

48.189

0.000

0.958

0.508

0,052

2.t07

0.076

0.000

0.176

0.371

0.201

0.705

0.071

0.177

0.315

0.000

0.000

0.000

0.334

0.000

0.216

0.000

2.404

0.761

Z7.119

9.091

1.587

0.964

0.050

D. 542

3.712

3.614

4949

5.922

0.000

0.060

0.000

0.0000

0.000

0.114

0.581

DUNSH

$09-893-6596$

13-571-1836

08434-3841

04-081-0053

0 0. $495-0350$

09-814-2180

$78-639-6390$

$07.326-098 B$

04-076-1330

07-523-7420

07-274-4030

06-827-9941

07-aB8-8197

19-480-1247

07-328-8144

$07-541-8998$

of -525-6172

$07-450-1900$

$08-743-9469$

05-270-4020

06-602-4957

00-718-8979

07-108.7806

07-106-3440

07-157-6482

$07-202-6321$

05-513-8864

$09-8813479$

06-720-2846

$07-605-4102$

07-157-9031

09-789-6120

$12406-3556$

07-178-2437

OB-611.0004

07-251-7473

B3-582-9789

00-687-3747

07-212-1621

07-122-2780

08-118-0754

07-550-1494

06-989-2263

10-360-2310

07-145-6953

07 - $477-7331$

07-546-3891

17-551-9828

$07-706-0216$

$07-709-8770$

04-836-4898

$07-372-7943$

$07.371-0378$

$03.855-6460$

08-223-1770 
DUNASi泣

sc.

SC

$\mathrm{sc}$

80

SD

$\mathrm{SD}$

SD

TN

TN

TN

TN

TN

TN

TN

Tx

TX

TX

TX

$\mathbf{T X}$

$\mathbf{T X}$

TX

TX

TX

$\mathbf{T X}$

TX

TX

DX

TX

TX

$\mathbf{T X}$

TX

$\mathbf{T X}$

TX

$\mathbf{T X}$

TX

TX

TX

$T x$

$T X$

TX

TX

$T x$

$T x$

$7 X$

TX

$\mathbf{T X}$

$\mathbf{T X}$

$7 x$

$\mathbf{T X}$

$T X$

TX

TX

TX

TX

VA

VA

VA

VA

VA
SOUTH CAROUNA STATE UNNERSTY

93.991

VOORHEES COLLEGE

COLUMIAA JUNOR COLLEGE OF EUSNASS

GENTRAL INDLAN BIELE COLLEGEASSEMEUES OF GOD

OGLALA LAKOTA COLLEGE

SNTE GLESKA UNVERSTY

SISSETONWAHPETON COMNUNTY COLLECE

FISK UNIVERETTY

KWOXVLLE COUEGE

LANE COLLEGE

HE MOYNE-OWEN COLLEGE

MEHARRY MEDICAL COUEGE

SHELBY STATE COMMUNTY COUEGE

TENMESSEE STATE UNNERSITY

BEE COUNTY COLLEGE

TEXAS A \& U UNNERSTY-CORPUS CHRST

DE: MAR COLLEEE

EL CENTRO COLLECE

HOUSTON COMHUNITY COLLEGE SYSTEM

UNWERSTY OF HOUSTON-DOWNTOWN

HUSTOHTLLOTSON COLLEGE

INCARNATE WORO COLLECE

ITT TECHNCAL NSTITUTEHOUSTON

JARVS CHRISTIAN COLLGE

LAREDO COMKUNTY COLIEGE

TEXAS A \& W INTERTATONAL UNWERMTY

MSS WADES FASHION MERCHANDISNG

MOUNTAN VEW COLLEGE

OPLATE SCHOOL OF THEOLOEY

OOESSA COLLEGE

OUR LADY OF THE LAKE UNNERSTY SAN ANTONO

THE UNNERGTY OF TEXASPAN AMERICAN

THE UNNERSTYY OF TEXAS AT BROWNBVLLE

PAUL QUNNN COLLEGE

PRAIRIE VIEW A \& M UNNERSTY

SANT EDWARDS UNMERSTY

ST PHILPS COUEGE

UNMERSITY OF SANTT THOMAS

SAN ANTONOO COLEGE

SAINT MARYS UNRERSTYY

SOUTH PLANS COLLEGE

SOUTHWEST TEXAS RUNIOR COUEGE

SOUTHNESTERN CHPISTLAN COLLECE

SUL ROSS STATE URWVRSITY

TEXAS A \& M UNNERSTYHANGSVULE

THE UNNERSTY OF TEXAS AT EL PASO

TEXAS COLLEGE

THE UNMERSITY OF TEXAS AT SAN ANTONHO

TEXAS SOUTHERN UNMERSTIY

TEXAS SOUTHMOST COLLEGE

TEXAS STATE TECHNICAL COLLEOEHARLNGEN CAMUS

WILEY COLLEGE

PALO ALTO COLIECE

SOUTHWEST WISTIUUTE DF MERCHANDIENGG AND DESIGN

COMMONWEALTH COLLEOE

COMMONHEALTH COLLEGE-HAMPTON

COAMONWEALTH COLLEEE-RICHMOND

HAMPTON UNMERETIT

NORFOLK STATE UNIVERSITY
$\$ 3.324$

79.530

64,000

82.177

75.000

68.528

99.656

$08,3.52$

100.000

99,234

28.667

62.745

67.763

62.036

38.239

55,406

62.521

50.379

65.625

89.580

50.669

54,338

99.476

93,347

85.692

53,441

52.823

27,193

33.915

56.531

88,313

79.991

99.700

89.092

32.705

65.804

30.933

55.859

54.201

31,688

74.291

07,363

47.803

66,658

67.399

98.297

42057

87,914

82317

85.6055

93,836

65.686

73.303

53.125

65.704

51.108

88.612
a1,75B
0.000

07.799-4770

$07-905.0846$

$07-371-7795$

12-270-3143

36-444-1659

07-291-8485

$10-227-4321$

05-214-4323

04-946-7160

$07.352-6691$

07-354-7630

04-143.8186

87-864-8054

19-881-4179

$07-460-8902$

0.5-10-0152

08-306-7359

$06-637-6278$

07-416-2462

$03-967.4494$

79-964-4407

11.9844538

61-501-3802

04904-9810

19-004-2234

$09.510-0095$

07-508-6439

08-637-6279

93-166-1363

aด-1030-7251

13-615-28 40

78-415-3860

800-18-79B5

04-329-6334

13-817-0220

NA

$07-400.2749$

05-111-2712

$07-460-2749$

07-850-0725

06-639-1004

$07+49-470 B$

$07-510-5775$

$07-760-8096$

04-291-5991

13-205.1285

07-514-9131

80-1018-9185

$05-028-8975$

07.692 .7524

$06+896-6345$

06-973-9985

$07-460-2749$

NA

07-792-8638

$12-413-9456$

$07-497-9488$

$00313-5038$

of $-475-4805$ 


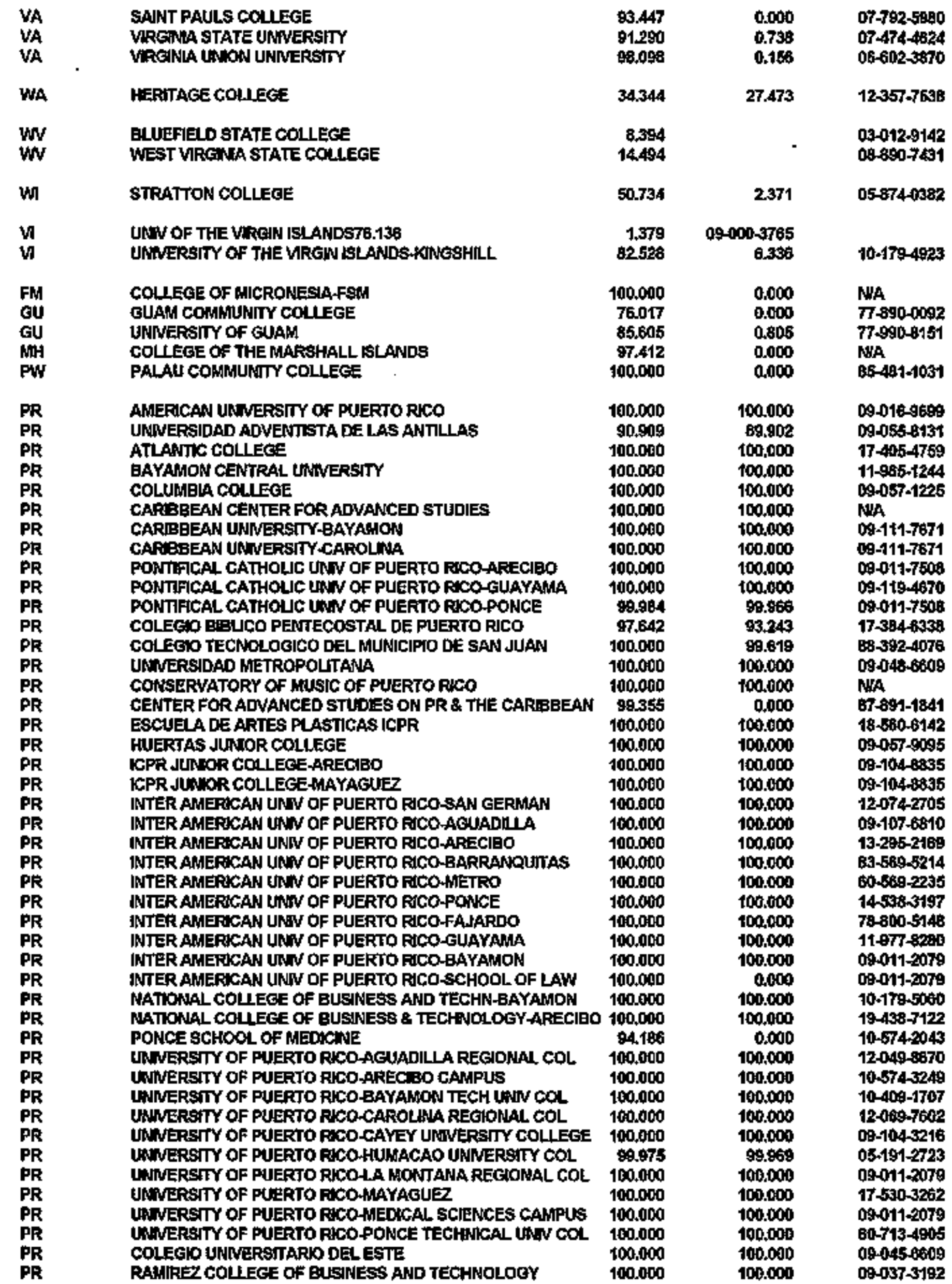


APPENDIX F (Con't)

STATE

PR

PR

PR

PR

PR

PR

PR

PR

PR

PR

PR

PR

PR

\section{WSTIUTONONAM:E}

UNNERETTY OF SACFED HEART

LNWERSDAD CENTRAL DEL CARBE

UNNERSADAD POLITECNICA DE PUERTO RICO

PONTIFICAL CATHOLEC UNN OF PUERTO RLCOMAYAGUEZ

UNDVESIDAD DEL TURABD

ELECTRONIC DATA PROCESSING COLLEGE OF PR INC

KCPR JUANOR COLLEGE-BEKIERAL NISTIUUTIONAL

CARBBEEAN UNNERESTYPONCE

CARBBEAN UNNERSITY-VEGA EAJA

MSTITUTO DE EDUCACION UNHERSAL

UNWERSTY OF PHOENXXPUERTO RICO CAMAUS

WTER AMERICAN UNNERSTY SCHOOL OF OPTONETRY

COLEGO UNNERSTIAFTO DEI ESTE
\%HINOPY

100.000

$\mathbf{9 8 . 5 1 6}$

100.000

100.000

100.000

100.000

100.060

100.000

100.000

100.000

100,000

100.000

100,000
\% HISPAN.C

100,000

100.000

100.000

100.000

100.000

100.000

100.000

100.000

100.000

100.000

0.001

0.000

100.000
Dutsü

09044:3011

09-053-4694

$09056-6707$

55.544-1088

$09-045-6809$

00.019 .1313

13-402-7683

09-111-7071

11-815-5142

01.709 .2123

10-408-7556

09.005 .1616

$09-045-6809$

Reloased: Decenther 11, 1995

For Further hiormation

Contrat Peler A. McCabe

Ortice for Chill Rights

U. Depatment of Education

Washington, D.C. 20242

(202) 205-9567 


\section{INITIATING OFFICE \\ TECHNICAL REPRESENTATIVE OFFICE}

$A B$

$A C$

$A D$

AL

AP

$B A$

$\mathrm{BC}$

$\mathrm{CH}$

$\mathrm{Cl}$

CR

DP

DS

ED

EE

EH

El

EM

EP

ER

EW

FA

FC

FD

FE

FM

FN

GC

GJ

GO

HG

HR

ID

IE

IG

IS

LC

LM

MB

$M C$

MD
Secretary of Energy Advisory Board

Departmental Advisory Committees

Office of Administration \& Human Resource Management

Albuquerque Operations Office

Alaska Power Administration

Chairman, Board of Contract Appeals

Bartlesville Project Office

Chicago Operations Office

Assistant Secretary for Congressional, Intergovernmental \& International Affairs

Chief Financial Offtcer

Assistant Secretary for Defense Programs

Deputy Secretary

Office of Economic Impact \& Diversity

Assistant Secretary for Energy Efficiency and Renewable Energy

Assistant Secretary for Environment, Safety \& Health

Energy Information Administration

Environmental Measurement Lab

Assistant Secretary Domestic \& International Energy Policy

Director of Energy Research

Environmental Restoration \& Waste Management

Federal Inspector for Alaska Gas Pipeline

Grand Forks Project Office

Office Field Menagement

Assistant Secretary for Fossil Energy

Office of Financial Management and Controller

Fernald Field Office

General Counsel

Grand Junction Project Office

Golden Field Office

Director of Hearings and Appeals

Assistant Secretary for Human Resources and Administration

Idaho Operations Office

Assistant Secretary for International Afiairs \& Energy Emergency

Inspector General

Office of Intelligence \& National Security

Laramie Project Office

Office of Laboratory Management

Miamisburg Area Office

Morgantown Energy Technology Center

Office of Fissile Material Disposition 
MT

NE

NN

NS

NV

OE

$\mathrm{OH}$

OR

PA

PC

PE

PN

PO

PP

QM

RF

RG

RK

RL

RT

RW

RO

R1

R3

R4

R5

R8

SA

SF

SL

SN

SP

SR

ST

SW

TC

TE

TR

US

WA

WE

WC

WD

WE
Metarie Site Office

Office of Nuclear Energy

Office of Nonprotiferation and National Security

Office of Nuclear Safety

Nevada Operations Office

Office of Emergency Planning \& Operations

Ohio Field Office

Oak Ridge Operations Office

Office of Public Affairs

Pittsburgh Energy Technology Center

Policy, Planning and Analysis

Pittsburgh Naval Reactors Office

Strategic Petraleum Reserve Office

Portsmouth Project Office

Office of Quality Management

Rocky Flats Operations Office

Economic Regulatory Administration

Petroleum Reserves Office - Kern

Richland Operations Office

Office of Sciertificic, Eng, Recr., Training, Development

Office of Civilian Radioactive Waste Management

Richland Support Office

Boston Support Office

Philadelphia Support Office

Atlanta Support Office

Chicago Support Office

Denver Support Office

Office of Safeguards \& Security

Oakland Operations Office

Scheduling and Logistics

Schenectady Naval Reactors Office

Southeastern Power Administration

Savannah River Operations Office

Office of the Science \& Technology Advisor

Southwestern Power Administration

Office of the Scientific \& Technical Infomation

Office of Science Education \& Technology information

Office of Scientific, Engineering, Recreation, Training, Dev.

Under Secretary

Western - Heacquarters Golden

Western - Billings Area Office

Western - Huron District Office

Western- Bismarck District Office

Western - Fort Peck District Office 
WF Westem - Watertown Operations Office

WG. Westem - Boulder City Area Office

WH Westem - Phoenix Area Office

WJ Westem - Loveland Area Office

WK Western - Montrose District Office

WL Western - Salt Lake City Area Office

WN Westem - Sacramento Area Office

WP Western Area Power Administration

WR Naval Petroleum And Oil Shale Reserves

WT Office of Worker and Community Transition

WW West Valley Area Office 